University of Michigan Law School University of Michigan Law School Scholarship Repository

2015

\title{
The Institutional Appetite for Quack Corporate Governance
}

\author{
Alicia J. Davis \\ University of Michigan Law School, alidavis@umich.edu
}

Available at: https://repository.law.umich.edu/articles/1635

Follow this and additional works at: https://repository.law.umich.edu/articles

Part of the Business Organizations Law Commons

\section{Recommended Citation}

Davis, Alicia J. "The Institutional Appetite for Quack Corporate Governance." Colum. Bus. L. Rev. 1 (2015).

This Article is brought to you for free and open access by the Faculty Scholarship at University of Michigan Law School Scholarship Repository. It has been accepted for inclusion in Articles by an authorized administrator of University of Michigan Law School Scholarship Repository. For more information, please contact mlaw.repository@umich.edu. 


\title{
THE INSTITUTIONAL APPETITE FOR "QUACK CORPORATE GOVERNANCE"
}

\begin{abstract}
Alicia J. Davis*
This Article offers evidence that higher quality internal corporate governance is associated with higher levels of ownership by institutional investors. This finding is consistent with the idea that institutions have greater reason than individual investors to prefer well-governed firms, but surprising given the substantial empirical evidence that casts doubt on the efficacy of internal governance mechanisms. The study described in this Article also finds that higher quality external governance is associated with lower proportions of ownership by certain types of institutional investors, also a somewhat surprising result given available empirical evidence on the positive relationship between external governance and firm performance. After largely dismissing
\end{abstract}

* Professor, University of Michigan Law School. For helpful conversations and comments on prior drafts and this paper's predecessor, I thank Steve Choi, John DiNardo, Mitu Gulati, Todd Henderson, Don Herzog, Jim Hines, Vic Khanna, Saul Levmore, Nina Mendelson, Martha Nussbaum, JJ Prescott, Adam Pritchard, Veronica Santarosa, Sonja Starr, Brady West and participants at the Annual Meeting of the American Law and Economics Association, the Conference on Empirical Legal Studies, the University of Chicago Law School's Best Ideas lecture series, the University of Michigan Law School Law and Economics Workshop, the University of Michigan Fawley lunch, and the University of Michigan Business Law Lunch. For research assistance, I thank Grady Bridges, Jesse Hogin, and Zachary Klausner, and for technical and administrative assistance, I thank Stephen Fuller and Karen Rushlow. For statistical consulting services on an earlier, related project, I am indebted to Ed Rothman and Heidi Reichert of the University of Michigan's Center for Statistical Consultation and Research. I also thank Paul Michaud and Kyle Schroeder for computer and technical assistance and Michael Ellenbogen, Anthony Rubin, and Caryn Smith for research assistance on an earlier, related project. Any errors are my own. The Cook Fund of the University of Michigan Law School and the Walter V. Schaefer Fund at the University of Chicago Law School provided financial support for this project. 
competing explanations for these findings, I conclude that institutional investors, as a group, generally prefer internal governance mechanisms over external governance mechanisms or have a higher tolerance for low-quality external governance than for low-quality internal governance. I argue that these preferences are reasonable and suggest that when debating the efficacy of governance mechanisms, the preferences of informed, sophisticated investors be afforded greater weight than is currently the case.

I. Introduction .......................................................... 3

II. Brief Overview of Corporate Governance................. 14

A. Sarbanes-Oxley, Dodd-Frank and Director Independence ..................................................15

B. Corporate Governance Ratings .........................27

C. The Market for Corporate Control .......................30

III. Research Objective, Data, Methodology and

Results of Analysis..................................................... 42

A. Research Objective .............................................42

B. Data and Sample ................................................. 42

C. Empirical Methodology and Results of

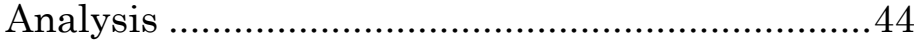

1. 2010 OLS Regression ....................................44

2. Pooled OLS Regression Analysis ...................60

3. Causation.......................................................63

IV. Alternative Explanations for Findings and Policy

Implications............................................................ 64

A. Review of Alternatives.....................................64

1. Misinformed or Irrational Investors ...............64

2. Agendas Unrelated to Wealth Maximization.................................................65

3. Blind Herding ...............................................66

4. Criticism Insurance.......................................68

5. Omitted Variable Bias....................................70

B. Policy Implications .......................................... 71

1. Internal Governance................................. 71

2. External Governance................................. 75

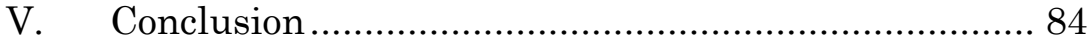

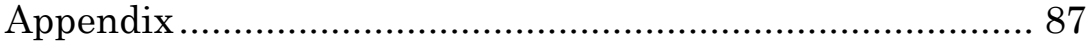




\section{INTRODUCTION}

Reading much of the legal scholarship from the last decade on U.S. corporate governance would leave one with the definite impression that the laws in the area are arbitrary and run counter to the evidence on the appropriate regulation of business activity. For example, ten years ago, Professor Roberta Romano roundly panned The SarbanesOxley Act ("Sarbanes-Oxley" or "SOX"), which was passed by Congress in the wake of large-scale accounting fraud scandals. $^{1}$ According to Professor Romano, empirical research on the substantive corporate governance mandates of Sarbanes-Oxley demonstrated that the required governance devices, including a mandate for all public companies to have $100 \%$ independent audit committees, would neither address the problem of accounting fraud nor increase firm value. This observation led Professor Romano to charge Congress with engaging in "quack corporate governance," i.e., legislating without regard to the relevant empirical research.

This charge was echoed by others in the academy ${ }^{2}$ and later applied to the governance mandates in The Dodd-Frank Wall Street Reform and Consumer Protection Act ("DoddFrank"), Congress' response to the 2008 financial crisis. In a piece titled "Dodd Frank: Quack Federal Corporate Governance Round II," Professor Stephen Bainbridge echoes the criticism leveled by Professor Romano against SarbanesOxley and argues that Dodd-Frank's governance mandates, including a requirement for all public companies to have fully independent compensation committees, have no basis in empirical research. ${ }^{3}$

The corporate governance "quackery" label has found application beyond Congressional legislation. Commercial

1 Roberta Romano, The Sarbanes-Oxley Act and the Making of Quack Corporate Governance, 114 YALE L.J. 1521 (2005).

2 See infra Part II.A.

3 Stephen M. Bainbridge, Dodd-Frank: Quack Federal Corporate Governance Round II, 95 MINN. L. REV. 1779, 1805 (2011). 
service providers, such as proxy advisory firm Institutional Shareholder Services ("ISS"), have developed metrics to assess the strength of corporate governance practices, and these metrics are now in widespread use by large, sophisticated investors. Professor Paul Rose argues that the corporate governance ratings touted by proxy advisory firms lack empirical support, as there is little evidence of a relationship between the governance practices encouraged by the ratings system and increases in firm valuation. ${ }^{4} \mathrm{He}$ is far from alone in his criticism. ${ }^{5}$

What the corporate governance provisions of SOX and Dodd-Frank and corporate governance ratings have in common is either an exclusive (in the case of SOX and DoddFrank) or predominate (in the case of governance ratings) focus on internal governance mechanisms - those things that relate to how the corporation is managed internally (e.g., independence of the board of directors). Very little is known about what works in corporate governance, and the empirical evidence on the efficacy of internal governance mechanisms is mixed, at best. Therefore, those academics critical of SOX, Dodd-Frank, and corporate governance ratings have understandably seized on the bevy of research that fails to show consistent relationships between internal governance quality and firm value.

Many reasons for Congress' purportedly wrong-headed focus on internal governance mechanisms in the promulgation of SOX and Dodd-Frank have been offered. These reasons relate to the vagaries of politics, the pressure that comes from legislating in times of crisis, and limited Congressional capacity to critically evaluate empirical research. ${ }^{6}$ Similarly, pecuniary incentives have been proffered as the reason behind the commercial corporate governance industry's interest in selling corporate governance ratings without regard to whether there is solid empirical evidence to suggest that the governance

4 See Paul Rose, The Corporate Governance Industry, 32 J. CoRP. L. 887, 910, 912, 914 (2007).

5 See infra Part II.B.

6 See infra Part II.A. 
mechanisms encouraged by the ratings systems improve corporate performance. ${ }^{7}$ The basic claim of the critics is that governance devices of, at best, questionable efficacy have been thrust upon the business community, either by legislative fiat or ratings pressure, to the detriment of firm value.

In stark contrast to the prevailing views on internal corporate governance, academics are largely united in their belief in the effectiveness of external governance-firm characteristics that maximize vulnerability to hostile takeovers (e.g., lack of a poison pill or classified board) ${ }^{8}$-in enhancing shareholder value. The received wisdom in the academy is that the only form of "effective governance" documented in the research literature is external corporate governance. ${ }^{9}$ Proponents of high-quality external governance assert that takeovers in the "market for corporate control" create value for shareholders, ${ }^{10}$ and Professor Lucian Bebchuk, for example, is leading the charge (and drawing the ire of prominent advocates of director primacy) ${ }^{11}$ to enhance shareholder power through the strengthening of external governance.

The line of demarcation between internal and external governance is not fixed, of course. There is an overlap between the two categories, and the two purportedly different types of governance mechanisms sometimes rely on one another for effectiveness. ${ }^{12}$ Indeed, there is evidence that external and internal governance are complements (i.e., exposure to the market for corporate control is only effective

7 See infra Part II.B.

8 See infra Part II.C. for the definitions of a poison pill and a classified (i.e., staggered) board.

9 See infra Part II.C.

10 See infra Part II.C. for a discussion of this point.

11 See Memorandum from Martin Lipton, Bite the Apple; Poison the Apple; Paralyze the Company; Wreck the Company, Wachtell, Lipton, Rosen \& Katz (Feb. 22, 2013), in ACTIVIST REP. 4 (Apr. 2013), available at http://hl.com/email/pdf/the-activist-report-april2013.pdf, archived at http://perma.cc/N834-LVK2.

12 David A. Skeel, Jr. et al., Inside-Out Corporate Governance, 37 J. CoRP. L. 147, 150-51 (2011). 
if there is strong internal governance in the form of a large monitoring stockholder that can facilitate a takeover). ${ }^{13}$ That said, researchers tend to think about types of governance devices that are internal to an organization separately from those mechanisms that serve to either facilitate or impede third-party takeover attempts.

In light of the evidence on the efficacy of various governance practices, Professor Jonathan Macey argues that a regulatory paradox exists. He argues that Congress, the Securities and Exchange Commission (the "SEC"), and the highly influential proxy advisory firms who promulgate commercial ratings promote internal governance mechanisms, which have not proven effective, while Congress, state legislatures, and courts not only fail to promote a robust market for corporate control, but also impede its effectiveness by sanctioning both the implementation of antitakeover mechanisms and their maintenance in the face of a hostile bid. ${ }^{14}$

There have been thousands of law review articles written about corporate governance in the past ten years. ${ }^{15}$ It is fair to say that the motivations and preferences of legislators, academics, courts, and, even to some extent, commercial governance ratings agencies have been thoroughly explored.

13 See K.J. Martijn Cremers \& Vinay B. Nair, Governance Mechanisms and Equity Prices, 60 J. FIN. 2859, 2860 (2005); infra Part II.

14 Jonathan R. Macey, Corporate Governance: Promises Kept, Promises Broken 46 (2008).

15 A Westlaw search for law review articles published between March 16, 2005, and March 15, 2015, with the term "corporate governance" in the title returns 442 results. Westlaw Search with "Corporate Governance" in the Title, WestlawNext, http://westlawnext.com (last visited Mar. 23, 2015) (search for "advanced: (TITLE(“corporate governance”)) \& DA(aft 0315-2005 \& bef 03-16-2015)," filter for "Secondary Sources" then "Law Reviews \& Journals"). The same search for law review articles with the term "corporate governance" appearing at least five times anywhere in the document yields 2,845 results. Westlaw Search with "Corporate Governance" at Least Five Times, WESTLAWNEXT, http://westlawnext.com (last visited Mar. 23, 2015) (search for "advanced: (ATLEAST5("corporate governance”)) \& DA(aft 03-15-2005 \& bef 03-16-2015)," filter for "Secondary Sources" then "Law Reviews \& Journals"). These results do not include articles written in finance or other business journals on this topic. 
What is missing from the empirical corporate governance literature is a comprehensive, detailed review of the governance preferences of an important constituencyinvestors. The relationship between institutional ownership and governance has been explored previously. For example, Professors Kee Chung and Hao Zhang show that higher proportions of institutional ownership are associated with higher governance quality as measured by fifty governance characteristics derived from ISS' corporate governance database ${ }^{16}$ Professors Brian Bushee, Mary Ellen Carter and Joseph Gerakos find little evidence of any association between corporate governance and institutional ownership overall, but do find that a subset of what they term "governance sensitive" institutions exhibits preferences for certain types of governance mechanisms. ${ }^{17}$ However, none of the previously produced studies explore the internal/external governance dichotomy or attempt to ascertain whether institutions generally or particular types of institutions prefer certain governance mechanisms to others. This paper is, to my knowledge, the first to do so.

This omission from the literature is odd since SarbanesOxley and Dodd-Frank were designed to "restore investor confidence" and "protect investors" following substantial lapses in corporate governance. ${ }^{18}$ Gaining an understanding of the specific governance preferences of the "protected class" makes sense. Of course, if the protected class is uninformed or incapable of understanding what is in its best interests, and one is apt to adopt a paternalistic approach to regulation, then one might pay scant attention to the

16 Kee H. Chung \& Hao Zhang, Corporate Governance and Institutional Ownership, 46 J. Fin. QuANTITATIVE ANALYsis 247, 269-70 (2011).

17 Brian J. Bushee, Mary Ellen Carter \& Joseph Gerakos, Institutional Investor Preferences for Corporate Governance Mechanisms, J. MGMT. ACCT. REs. (forthcoming June 2013) (manuscript at 3).

18 Sarbanes-Oxley Act of 2002, Pub. L. No. 107-204, 116 Stat. 745 (2002); Impact of the Sarbanes-Oxley Act, Hearing Before the H. Comm. on Fin. Servs., 109th Cong. 7, 45, 61 (2005) (testimony of Hon. William H. Donaldson, Chairman, Securities and Exchange Commission). 
preferences of the protected class. However, if there is a group within the protected class that has reason to prefer well-governed firms and that is capable of assessing the value of governance practices, then understanding its preferences can help inform policy debates. With respect to corporate governance, such a group exists-namely, sophisticated institutional investors.

Most retail (individual) investors, given their small investment stakes, rationally opt not to expend time, effort, and money monitoring the corporate governance practices of the firms in which they invest. ${ }^{19}$ On the other hand,

19 A number of researchers have provided reasons for why retail investors care less about corporate governance than institutional investors. For example, Professors Sanford Grossman and Oliver Hart, in describing the free-rider problem, note that it is not cost effective for small shareholders to monitor management. Sanford J. Grossman \& Oliver D. Hart, Takeover Bids, the Free-Rider Problem, and the Theory of the Corporation, 11 BELL J. ECON. 42, 42 (1980). Evidence supports the view that retail investors are generally passive with respect to governance matters. Not only are there few reported instances of retail investors waging activist campaigns to force governance changes, but individual investors also vote in corporate elections at a low rate. The percentage of retail investors participating in routine corporate elections is estimated to be approximately $20 \%$ on average and is as low as $5 \%$ at some firms. Frank G. Zarb, Jr., Restoring Balance in Proxy Voting: The Case For "Client Directed Voting," Harv. L. Sch. F. on Corp. Governance \& Fin. REG. (Feb. 14, 2010, 8:39 AM), http://corpgov.law.harvard.edu/ 2010/02/14/restoring-balance-in-proxy-voting-the-case-for-client-directed-

voting/, archived at http://perma.cc/3RMA-JXNV. Therefore, individual investors are largely believed to focus less on corporate governance than institutions do. However, despite the hypotheses set forth by researchers and the voting evidence, survey evidence calls into question the notion that individual investors are largely indifferent to corporate governance. Professors Jeffrey Cohen, Lori Holder-Webb, Leda Nath, and David Wood surveyed 750 retail investors and asked them questions about the types of non-financial information they use when making investment (buy-sell) decisions. Not surprisingly, retail investors used non-financial information directly related to economic performance the most, with over $60 \%$ of those surveyed indicating that, for example, they frequently use information on market share and product innovation. However, a substantial percentage of respondents (ranging anywhere from approximately 38\% for board selection processes to $52 \%$ for executive compensation) also revealed that they frequently use various types of corporate governance information 
institutional investors, because of their relatively larger stakes, have more incentive to monitor, particularly if it is costly to exit. ${ }^{20}$ Since owning shares in a well-governed firm reduces an investor's own monitoring costs, such investments are attractive to institutional investors. In addition, institutions, because of fiduciary duty concerns, are more vigilant about making "prudent" investments that are less likely to lead to large losses. Institutional investors also prefer well-governed firms because there is evidence that suggests the stocks of such firms have higher liquidity and lower associated trading costs. ${ }^{21}$

This Article describes a study that provides detailed data on institutional investor governance preferences. To the extent any conclusions can be reached in this area, the weight of the empirical evidence on corporate governance suggests that returns are enhanced by investing in firms with (at least) high-quality external governance. Therefore, a reasonable hypothesis, given the previously available evidence, would be that institutional ownership is associated with high-quality external governance. Though I find that high-quality external governance in the form of annual director elections (i.e., non-staggered boards) is associated with higher proportions of overall institutional ownership in one model specification (a relationship likely driven largely by mutual fund preferences), in another model specification, higher external governance quality as quantified by the GIndex, a measure of exposure to the market for corporate control, is associated with lower proportions of overall

when making investment decisions. On average, however, the investors surveyed indicated that, though they consider corporate governance information, they do not rely on it heavily in their decision making processes. Jeffrey Cohen, et al., Retail Investors' Perceptions of the Decision-Usefulness of Economic Performance, Governance, and Corporate Social Responsibility Disclosures, 23 BeHAV. RES. ACCT. 109, 116, 117 tbl.3 (2011).

20 Chung \& Zhang, supra note 16 , at 250 . To be sure, a number of institutional investors also appear largely indifferent to corporate governance, but the claim being raised here relates to their interest, as a group, relative to individual investors' interest, as a group.

21 Id. at $250-51$. 
institutional ownership. This study's results also reveal that there is a relationship between ownership by certain institutional investors, including, most notably, public pension funds, and low-quality external corporate governance in most model specifications. My analysis also reveals that high-quality internal governance, as measured by internally-focused governance metrics such as the ISS Corporate Governance Quotient ("ISS CGQ"), is associated with higher proportions of overall institutional ownership. Overall, the evidence reveals a relationship between institutional ownership, on the one hand, and high-quality internal governance and, in some cases, low-quality external governance, on the other hand.

One note of clarification is in order. This study reveals institutional investor preferences relative to those of other market participants (i.e., individual investors) ${ }^{22}$ and suggests that institutions value purportedly high-quality internal governance more highly than individual investors and purportedly high-quality external governance less highly than individual investors. Thus, when I describe institutional investor "preferences" in this paper, I am referring to their "relative preferences."

In capital markets equilibrium, all stocks are held by someone, and all firms have owners. The stock price tells us how the market as a whole values a particular set of firm characteristics. This study does not compare the stock prices of firms with particular governance characteristics to determine overall market preferences. Rather, it looks at which investors hold the stock of certain types of firms and compares the number of shares held by institutions with those held by individuals. The study's results suggest that (1) institutions self-select into firms with (and/or encourage firms to adopt mechanisms that reflect) purportedly high-

22 In this study, "institutional investor" is defined as institutions with $\$ 100$ million or more under discretionary management. See infra note 181. For ease of exposition, I refer to market participants other than these institutions, which include individual investors, as well as institutions with less than $\$ 100$ million under discretionary management, as "individual investors." 
quality internal governance, and (2), in some cases, selfselect into firms with (and/or encourage firms to adopt mechanisms that reflect) purportedly low-quality external governance.

Assume for the sake of argument that all investors agree that better corporate governance leads to better firm performance. If this were the case, we would expect better governance to be priced into the stock (i.e., better governed firms, all else being equal, would have higher market valuations). Note, however, that not everyone will increase their investment in firms that improve the quality of corporate governance or buy the stock of firms with highquality governance characteristics. Instead, those that value the characteristics most highly (and are willing to pay for the attributes) will outbid those investors that value the characteristics less highly. The results of the instant study, which reveal higher institutional investment in firms with high-quality internal governance and, in many cases, lower institutional investment in firms with high-quality external governance, suggest that, on the whole, institutional investors believe that internal governance quality is more likely than external governance quality, holding all else equal, to lead to better firm performance.

This all suggests that institutional investors, like Congress, prefer "quack corporate governance"-what I am using as a generic term ${ }^{23}$ for governance mechanisms upon

23 Though my results show a preference for greater director independence, which underlies the reasoning for audit and compensation committee independence requirements, my data do not reveal a direct association between institutional ownership and the particular elements of SOX to which Professor Romano refers as examples of "quack corporate governance" (i.e., independent audit committees, restrictions on the provision of non-audit services, executive certification of financial statements, and the prohibition on executive loans). My data also do not reveal a direct association between institutional ownership and the particular elements of Dodd-Frank upon which Professor Bainbridge focuses (i.e., mandated shareholder advisory votes on executive compensation, independent compensation committees, new compensation disclosure requirements, affirmation of the SEC's authority to promulgate 
whose efficacy the empirical evidence casts substantial doubt. One could draw a number of conclusions about the reasons for these governance preferences of institutional investors. It could be the case that institutional investors are just as misinformed as Congress or that some institutional investors have political agendas unrelated to wealth maximization and invest to advance policy goals rather than profitability. It is also possible that institutional money managers are blindly following the governance recommendations of proxy advisory firms such as ISS without independent evaluation of the efficacy of the mechanisms promoted in the ratings index either due to laziness or due to a desire to insulate themselves from criticism should there turn out to be a significant governance breakdown at one of their portfolio firms. For reasons I discuss in Section IV, I find all of these potential explanations wanting and conclude instead that the most likely explanation is that these preferences exist because institutional investors believe high-quality internal governance devices to be value enhancing.

I argue that my findings have significant implications for the quack corporate governance debate. Stockholders, as the residual claimants of a corporation, bear the costs of both poor governance and the implementation of ineffective governance mechanisms. Institutions, which are run by professional managers, know their preferences better than legislators or academics. If these sophisticated investors prefer high-quality internal governance over high-quality external governance, despite the seemingly limited empirical support for internal governance devices, this preference should be afforded greater weight than is currently the case in the debate about the efficacy of these mechanisms.

The seeming preference by some types of institutional investors for low-quality external governance demonstrated in this study is a bit more surprising, particularly in light of the public opposition by certain prominent public pension

rules related to shareholder proxy access for director nominees and disclosure of dual CEO/Chairman positions). 
funds to antitakeover devices such as staggered boards. One reason for this apparent inconsistency could be that the corporate governance groups of many institutional investors are responsible for voting and proxy decisions, while the portfolio managers are responsible for investing decisions. ${ }^{24}$ The corporate governance groups' raison d'etre is to impose "best practices" on portfolio companies. For years, wellknown and highly respected legal scholars have repeatedly made the case that antitakeover devices are value destroying. ${ }^{25}$ It is not surprising, then, that those tasked with improving corporate governance would find such mechanisms objectionable. Those investing, however, may have different priorities.

These different priorities may arise because portfolio managers, perhaps more than members of corporate governance staffs $^{26}$ realize that external governance is costly. Though many internal governance improvements (e.g., replacing inside directors with outside directors) are relatively inexpensive, for companies with the highest levels of vulnerability to hostile activity, removing protective devices (e.g., de-staggering the board) has significant ramifications. Portfolio managers realize the trade-offs inherent in holding management accountable and protecting their portfolio companies against opportunistic attack. These managers may err on the side of preferring or at least tolerating protective devices, secure in the knowledge that, as large investors, they have some ability to pressure management into accepting a truly value-enhancing takeover bid, should one materialize, despite the presence of defensive mechanisms. In addition, there is limited evidence that takeover defenses, including staggered boards, are

24 Brandon S. Gold, Agents Unchained: The Determinant of Takeover Defenses in IPO Firms 56 (May 6, 2013) (unpublished manuscript) available at http://papers.ssrn.com/sol3/papers.cfm?abstract_id=2262095, archived at http://perma.cc/8THY-9X57.

25 See infra Part II.C.

26 But see infra note 304 for evidence of a willingness to be flexible on some governance matters for IPO firms. 
associated with higher firm values. ${ }^{27}$ Therefore, portfolio managers who invest in firms with antitakeover mechanisms in place may be acting rationally. Given these facts, I submit that, before criticizing legislators or courts for impeding the market for corporate control by making it easier for boards to resist hostile activity, one might want to consider the role institutional investors play in the perpetuation of antitakeover devices.

The Article proceeds as follows. Part II briefly discusses the state of the empirical literature with respect to corporate governance and describes some recent efforts to improve corporate governance in the United States, specifically through Sarbanes-Oxley and Dodd-Frank. Part III describes the data and analytical methodologies of this study and presents results. Part IV considers the policy implications of these findings and also considers alternative explanations for the revealed governance preferences of institutional investors. Part V concludes.

\section{BRIEF OVERVIEW OF CORPORATE GOVERNANCE}

In the modern public corporation, the separation between ownership (i.e., by thousands of dispersed shareholders) and control (i.e., by professional managers) ${ }^{28}$ creates agency costs. $^{29}$ Corporate governance mechanisms are designed to

27 See infra Part II.C.

28 See Adolf A. Berle, Jr. \& Gardiner C. Means, The Modern Corporation AND PRIVATE Property 120-21 (1932).

29 There are three principal components of agency costs: (1) monitoring costs, the costs undertaken by the principal to limit divergence from her interests (e.g., developing appropriate incentives, costs of monitoring to limit the aberrant activities of the agent); (2) bonding costs, the costs of the agent to guarantee that she will not take certain actions to harm the principal or to ensure that the principal will be compensated if she does take those actions (e.g., insurance policy, financial penalty clause); and (3) residual loss, or the dollar value of the reduction in the principal's welfare due to the agent's divergence from activities that would maximize the principal's welfare. Residual loss is the loss that is left over after the incurrence of any monitoring and bonding costs. Michael C. 
increase managerial accountability, ${ }^{30}$ thereby decreasing agency costs. With every new scandal-ranging from the massive accounting frauds of Enron and WorldCom in the early 2000s to the collapse or near collapse of large financial institutions during the 2008 financial crisis-confidence in the ability of corporate governance mechanisms to reign in managerial excess wanes, leading to capital markets turmoil. ${ }^{31}$

This repeating cycle of crisis and turmoil leads to a continuous call for governance reform. Therefore, understanding what works in corporate governance is critical. There have been thousands of studies undertaken by law and finance professors that attempt to ascertain what mechanisms-both internal and external-increase shareholder value and minimize agency costs. Though no complete consensus on what does and does not work in corporate governance exists, the weight of the evidence seems to suggest that there is little to no relationship between internal governance quality and firm value. On the other hand, the empirical literature seems to suggest that there is a strong relationship between high-quality external governance (i.e., high exposure to the market for corporate control) and shareholder value. In this Part, I briefly describe the literature on corporate governance in the context of efforts to improve corporate performance through Sarbanes-Oxley, Dodd-Frank, corporate governance ratings, and the market for corporate control.

\section{A. Sarbanes-Oxley, Dodd-Frank and Director Independence}

The Sarbanes-Oxley Act, passed in July 2002, was Congress' response to the waning confidence in the capital

Jensen \& William H. Meckling, Theory of the Firm: Managerial Behavior, Agency Costs and Ownership Structure, 3 J. Fin. Econ. 305, 308 (1976).

30 See generally Douglas M. Branson, Proposals for Corporate Governance Reform: Six Decades of Ineptitude and Counting, 48 WAKE Forest L. REV. 673, 676 (2013).

31 Jill E. Fisch, The Overstated Promise of Corporate Governance, 77 U. CHI. L. REV. 923, 925-27 (2010). 
markets in the early 2000s. SOX contained substantial regulations affecting the corporate governance practices of public corporations, including the following governance mandates: (1) a requirement that company audit committees be composed exclusively of independent directors, (2) a ban on the provision of non-audit services by corporate auditors, (3) a ban on the provision of loans by the corporation to executives, and (4) a requirement for executive certification of financial statements. ${ }^{32}$ Sarbanes-Oxley ushered in a new era of federal regulation and invited its share of criticism, both substantive and process-oriented.

Since the passage of SOX, the most vocal opponent of the legislation in the legal academy has been Professor Roberta Romano. She argues that no case exists for the primary corporate governance provisions contained in SarbanesOxley. ${ }^{33}$ In a well-known article, Professor Romano methodically walks through each governance mandate in SOX and argues that each one was "seriously misconceived," as the "extensive empirical literature" suggested that these mandates were unlikely to either improve the quality of financial audits or improve corporate performance and provide benefits to investors. ${ }^{34}$ This is puzzling, she argues, as she wonders what type of legislative process could result in laws that in all likelihood would not generate their intended effect, namely an increase in shareholder welfare. ${ }^{35}$

The story Professor Romano tells is one of legislating in a time of crisis. The Sarbanes-Oxley Act was adopted in July 2002, less than one year after Enron's implosion, amid a

32 Sarbanes-Oxley Act of $2002 \S 201,15$ U.S.C. $\S 78 j-1$ (2013) (nonaudit services ban); Sarbanes-Oxley Act of $2002 \S 402,15$ U.S.C. $\S 78 \mathrm{~m}$ (2013) (ban on loans to executives); Sarbanes-Oxley Act of $2002 \S 906,18$ U.S.C. $§ 1350$ (2013) (executive officer certification); Sarbanes-Oxley Act of $2002 \S 301$, Pub. L. No. 107-204, 116 Stat. 775,775-77 (2002) (audit committee independence); Sarbanes-Oxley Act of $2002 \S 302$, Pub. L. No. 107-204, 116 Stat. 777,777-78 (2002) (executive officer certification).

33 Romano, supra note 1 , at 1543.

34 See id. at 1602.

35 Id. at 1543 . 
sharply declining stock market. ${ }^{36}$ Beginning in December 2001, Congress held a number of hearings on Enron's failure, its causes and potential legislative solutions. ${ }^{37}$ In April 2002, the House of Representatives passed a bill following seven hearings in the House Financial Services Committee. ${ }^{38}$ However, the Senate did not consider any legislation until shortly after WorldCom's collapse in July 2002. ${ }^{39}$

WorldCom's demise followed revelations of accounting fraud, corporate misconduct, and bankruptcy filings at a number of leading public companies such as Tyco, Adelphia, and Global Crossing. ${ }^{40}$ Moreover, the stock market dropped precipitously during the time Congress was considering Sarbanes-Oxley, ${ }^{41}$ with a sharp market decline beginning in April 2002, and a bottoming out in July 2002. ${ }^{42}$ The market's July 2002 low, which occurred on the second trading day after WorldCom's bankruptcy filing and the day before the conference committee reported out a bill (July 23), represented a decline of more than one-third in value over the prior year. ${ }^{43}$ In short, Congress was operating in an environment of staggering investor losses and low investor confidence. ${ }^{44}$ Given the steep market decline from April to July 2002, members of Congress perceived that legislative inaction was not an option. ${ }^{45}$

Professor Romano is highly critical of the Congressional legislative process and argues that this crisis situation led to the adoption of laws that the scholarly literature showed would not be effective. According to Professor Romano, the relevant evidence either went unnoticed or was ignored by

\footnotetext{
36 Id. at 1544 .

37 Id.

38 Id. at 1545.

39 Id.

40 Id.

41 Id.

42 Id. at 1546.

43 Id.

44 Id.

45 Id. at 1549.
} 
Congress ${ }^{46}$ and the witnesses called during the hearing process not only failed to enlighten Congress about the state of the empirical literature, ${ }^{47}$ but, in some cases, so-called "policy entrepreneurs" brought their own misguided agendas for governance reform. ${ }^{48}$

It is noteworthy that, despite Sarbanes-Oxley's stated purpose of restoring "investor confidence," investors played only a minor role in the SOX hearings. Only five of the sixtyfive witnesses $(7.7 \%)$ called by Congress during the House and Senate hearings were institutional investor representatives. ${ }^{49}$ One of these witnesses, John Biggs, CEO of TIAA-CREF, was called not as a representative of TIAA$\mathrm{CREF}$, but rather, due to his role as a member of the Blue Ribbon Committee on Improving the Effectiveness of Corporate Audit Committees and the Public Oversight Board. ${ }^{50}$ In contrast, academics and policy analysts comprised eight of the total sixty-five witnesses (12.3\%), while current or former government officials comprised eighteen of the sixty-five $(27.7 \%){ }^{51}$

Professor Romano points to an extensive body of literature that, she argues, demonstrates that the governance provisions in SOX would not generate their intended effects. She describes studies that not only find that independent boards fail to improve corporate performance, but also suggest that having too many outsiders on a board

46 Id. at 1526 .

47 See, e.g., id. at 1575-76 ("Millstein in his testimony never referred to the existence of a literature at odds with his position on board independence, of which he was fully aware, given that he had coauthored an article at variance with the literature on the point. The literature was instead treated as though it did not exist."). Note that Millstein's specific independence recommendations referred to the full board (a substantial majority), nominating committees, and compensation committees.

48 The idea for fully independent audit committees, for example, appears to have come from former SEC Chief Accountants Lynn Turner and Michael Sutton, both witnesses at the Senate hearing. See id. at 1574.

49 Id. at 1569.

50 See id. at 1571 n.139.

51 See id. at 1569 tbl.3. 
can be harmful. ${ }^{52}$ She acknowledges that the literature on the relationship between audit committee independence specifically and firm performance is not as extensive as that on full board independence (there are four studies on which Professor Romano relies), but points out that none of those studies finds any relationship between audit committee independence and company performance. ${ }^{53}$ Professor Romano further notes that of sixteen studies on the relationship between audit committee independence and financial reporting misconduct, ten fail to find that full audit committee independence lessens accounting improprieties, and one yields inconsistent results. ${ }^{54}$ She acknowledges that five studies do show some relationship between full audit committee independence and fewer cases of financial reporting misconduct. ${ }^{55}$ Overall, however, Professor Romano believes this hardly constitutes a case for the SOX audit committee mandate.

Professor Romano is not alone in her skepticism. Professor Larry Ribstein, for example, writes:

Post-Enron reforms, including Sarbanes-Oxley, rely on increased monitoring by independent directors, auditors, and regulators who have both weak incentives and low-level access to information. This monitoring has not been, and cannot be, an effective way to deal with fraud by highly motivated insiders. Moreover, the laws are likely to have significant costs, including perverse incentives of managers, increasing distrust and bureaucracy in firms, and impeding information flows. ${ }^{56}$

Also, in response to New York Times business columnist Joseph Nocera's assertion that one of the benefits of SOX is that auditors will no longer report to management and

52 See id. at 1530.

53 See id.

54 See id. at 1532.

55 See id. at app.A at 1604-05.

56 Larry E. Ribstein, Market vs. Regulatory Responses to Corporate Fraud: A Critique of the Sarbanes-Oxley Act of 2002, 28 J. CoRP. L. 1, 3 (2002). 
instead will report to the audit committee, which must be composed entirely of independent directors, Professor Stephen Bainbridge remarked that "[n]obody has yet shown that [this change] would have prevented debacles like Enron or will do so in the future. Indeed, Enron itself had an independent audit committee headed by Robert Jaedicke, a professor of accounting at Stanford University, who could hardly have been more qualified for the job." 57

The charge of quack corporate governance also has been applied to the governance mandates contained in DoddFrank, legislation born of the worst U.S. and global financial crisis since the Great Depression. ${ }^{58}$ The financial crisis yielded a loss of $\$ 17$ trillion of household wealth and the shedding of 8.3 million jobs in the U.S. from 2008-2009. ${ }^{59}$ To stem the crisis, the U.S. government undertook extraordinary actions, including creating the $\$ 700$ billion TARP (Troubled Assets Relief Program) relief package and investing an additional $\$ 787$ billion in the American Recovery and Reinvestment Act, an economic stimulus program. ${ }^{60}$ The financial industry disruptions were not limited to the U.S., as many countries around the globe required massive multi-billion dollar bailouts. ${ }^{61}$

Many believed that the crisis was largely caused by ineffective regulation of the financial sector. ${ }^{62}$ In the midst of the fall-out, Congress and the White House felt compelled to act. In January 2009, a New York Times editorial called on the leaders in Washington to make drastic changes to the regulatory landscape and said, "[a]nything less than a new

57 Stephen M. Bainbridge, Sarbanes-Oxley: Legislating in Haste, Repenting in Leisure, 2 CORP. GovernANCE L. REV. 69, 89 (2006).

58 Michael S. Barr, The Financial Crisis and the Path of Reform, 29 YALE J. ON REG. 91, 92 (2012).

59 Eugene A. Ludwig, Assessment of Dodd-Frank Financial Regulatory Reform: Strengths, Challenges, and Opportunities for a Stronger Regulatory System, 29 YALE J. ON REG. 181, 182 (2012).

$60 \mathrm{Id}$.

61 Id. at $182-83$.

62 See, e.g., Barr, supra note 58, at 93-96 (discussing the origins of the financial crisis). 
rules-based regime would be inadequate to the task of restoring confidence and, eventually, reviving the economy." 63 In July 2010, amid this environment of political urgency and economic uncertainty, Congress enacted DoddFrank. ${ }^{64}$

The most sweeping piece of financial reform legislation since the New Deal, Dodd-Frank, among other things, comprehensively regulates derivatives markets, provides for new means of data collection and financial sector transparency, and creates a mechanism for the liquidation of failing financial firms that does not put the economy or taxpayers at risk. ${ }^{65}$ Dodd-Frank also created the Consumer Financial Protection Bureau and provided for new consumer and investor protections. ${ }^{66}$

Additionally, Congress responded to a widespread belief that executive compensation practices were part of the problem. Specifically, there was a worry that incentive-based compensation led to short-term thinking and excessive risktaking. ${ }^{67}$ Dodd-Frank therefore contains a number of provisions intended to reduce this moral hazard and more effectively tie executive pay to long-term performance. ${ }^{68}$ These provisions include mandating non-binding shareholder advisory votes on executive compensation (Section 951),

63 Ludwig, supra note 59, at 183.

64 Id.

65 Barr, supra note 58, at 92.

66 Id.

67 John C. Coffee, Jr., The Political Economy of Dodd-Frank: Why Financial Reform Tends to Be Frustrated and Systemic Risk Perpetuated, 97 CoRNELl L. REV. 1019, 1047 (2012) ("Because a rapid shift towards incentive-based compensation at financial institutions focused senior management on short-term results, longer-term risks were ignored or excessively discounted. For example, if the executives in charge of assetbacked securitizations at a financial institution could make $\$ 100$ million in bonuses in a single year if sufficient deals closed that year, such expected compensation could easily produce a 'damn-the-torpedoes, full-speedahead' approach to risk taking. Indeed, why should executives so compensated worry at all about the longer-term risks to their bank? Thus, excessive compensation led to moral hazard.”).

68 Id. at 1065 . 
disclosure of the ratio of CEO pay to that of the median company employee (Section 953), mandating the recovery of compensation awarded in error (Section 954), and disclosure of director and employee hedging (Section 955). The provision of Dodd-Frank most relevant for present purposes is Section 952: "Compensation Committee Independence."

Section 952 of the Dodd-Frank Act requires the SEC to promulgate a rule requiring the stock exchanges to mandate that listed companies (with few exceptions) have compensation committees made up entirely of independent directors. ${ }^{69}$ Section 952 further requires the SEC to consider, when developing its definition of "independence," factors that include whether the director receives any compensation from the company (e.g., consulting fees) and whether the director is affiliated with the company or any of its subsidiaries or affiliates. ${ }^{70}$ In June 2012, the SEC adopted Rule 10C-1 of the Securities Exchange Act of 1934 to implement this provision, ${ }^{71}$ and on January 11,2013 , the New York Stock Exchange and NASDAQ finalized their listing standards, which had an effective date of July 1, 2013, to comply with Rule $10 \mathrm{C}-1 .{ }^{72}$

Professor Stephen Bainbridge, in his piece "Dodd Frank: Quack Federal Corporate Governance Round II," criticizes Dodd-Frank's requirement of complete compensation committee independence. ${ }^{73}$ The rationale for independent

69 Dodd-Frank Wall Street Reform and Consumer Protection Act § 952(a), Pub. L. No. 111-203, 124 Stat. 1900, 1900 (2010).

70 Id. at 1901.

71 Melissa Maleske, NYSE and Nasdaq Propose Compensation Committee Independence Standards, Inside Counsel (Nov. 28, 2012), http://www.insidecounsel.com/2012/11/28/nyse-and-nasdaq-proposecompensation-committee-ind, archived at http://perma.cc/TFT7-M5DC.

72 J. Mark Poerio et al., NYSE and Nasdaq Issue FINAL Listing Rule Changes for Compensation Committees and Compensation Advisers, PAUL HASTINGS (Feb. 2013), http://www.paulhastings.com/assets/publications/ 2344.pdf, archived at http://perma.cc/25SY-EQXD.

73 Bainbridge, supra note 3 , at 1805 . As it turns out, the new standards did not represent a drastic change from prior practice. Since 2003, the NYSE had mandated 100\% independent compensation committees, and Nasdaq required either 100\% independent compensation 
compensation committees lies in the assumption that independent directors are more likely to bargain over executive pay and, in turn, prevent excessive or illconsidered compensation. ${ }^{74}$ However, the available empirical evidence, argues Professor Bainbridge, suggests that this is not the case. Rather, studies show that director independence does not lead to better compensation decisions. Professor Bainbridge further notes that the independent compensation committee provision was supported by the Council of Institutional Investors, a pension fund trade association, and describes it as a "one-size-fits-all model being forced on all public companies."75 In addition, Professor Bainbridge asserts that, like other Dodd-Frank governance mandates, the compensation committee independence requirement lacks empirical support, as most studies reject the hypothesis that independence is associated with better firm performance or CEO compensation practices. ${ }^{76}$ Indeed,

committees or, in the absence of a standing compensation committee, all executive compensation decisions to be made by majority vote of a firm's independent directors. See Maleske, supra note 71. Furthermore, the 2003 listing standards did not represent a dramatic leap from then-current practice. Just prior to the institution of the stock exchange mandate for full compensation committee independence, on average, $92 \%$ of compensation committee members in a sample of 1,269 public companies were independent, and $77 \%$ of the public companies in this sample had fully independent compensation committees. See Jolene DUGAn ET AL., Institutional Shareholder Services, BoArd Practices/Board Pay 1, 20 (2006). These independence percentages are based on the definition of independence set forth by ISS GRS and exclude directors who provide (or have immediate family members or related entities that provide) professional services to the company or an executive and also exclude significant stockholders. Id. at 2. (This definition is more stringent than that of the stock exchanges for independence. Thus, under the stock exchange definition, a higher percentage of firms had independent compensation committee members.) The new listing standards promulgated pursuant to Dodd-Frank do include, however, as described above, a heightened standard of independence and a new Nasdaq requirement for a compensation committee. Poerio et al., supra note 72 .

74 Erica Beecher-Monas, The Risks of Reward: The Role of Executive Compensation in Financial Crisis, 6 VA. L. \& BUs. REV. 101, 120 (2011)

75 Bainbridge, supra note 3, at 1805.

76 Id. 
there is some evidence that higher levels of independence are (counter-intuitively) associated with higher levels of executive compensation. ${ }^{77}$

Not all scholars are as critical of Sarbanes-Oxley and Dodd-Frank. Professor Jack Coffee, for example, though acknowledging the shortcomings of the legislation, takes exception with the characterizations of SOX and Dodd-Frank set forth by Professors Romano and Bainbridge. He argues that crises are rare opportunities to overcome legislative inertia and effect necessary regulation. ${ }^{78}$ In addition, Professors Robert Prentice and David Spence offer a defense of SOX. They concede that Congress did not spend much (if any) time reviewing the empirical literature related to corporate governance before passing SOX. ${ }^{79}$ However, they argue that it goes too far to allege that enacting legislation inconsistent with the majority view of a large number of disparate studies reaching wide-ranging conclusions is "automatically [a] major gaffe. ..." 80 The scholars point to a number of studies (some of which, they admit, were conducted post-SOX enactment) that support the SOX governance provisions criticized by Professor Romano and others. ${ }^{81}$ Much of the evidence relates to the perennial question of the efficacy of board independence.

The academic literature on the question of whether having more independent boards increases firm value or profitability is decidedly mixed, but there is evidence that certain beneficial practices accompany higher levels of board independence, including more willingness to replace underperforming CEOs and creating more value in connection with corporate takeovers. ${ }^{82}$ Also, according to

77 Beecher-Monas, supra note 74, at 121.

78 Coffee, supra note 67, at 1036.

79 Robert A. Prentice \& David B. Spence, Sarbanes-Oxley as Quack Corporate Governance: How Wise Is the Received Wisdom?, 95 GEO. L.J. 1843, 1845 (2007).

80 Id.

81 Id.

$82 I d$. at 1865 . See also $i d$. at 1865 n.114 for a list of studies that detail ways in which board independence is associated with creating value for 
Professors Andrew Fields and Phyllis Keys, there is "overwhelming support among financial researchers for outside directors providing beneficial monitoring and advisory functions to firm shareholders." 83

Professors Prentice and Spence further argue that Congress passed SOX, not in hopes of improving firm performance, but in hopes of improving the accuracy of financial statements, stem the tide of corporate fraud, ${ }^{84}$ and restore investor confidence. ${ }^{85}$ The empirical evidence, Professors Prentice and Spence argue, does support the view that higher levels of board independence translate into more accurate financial reporting. ${ }^{86}$ For example, studies show that firms with more independent boards engage in less earnings management ${ }^{87}$ and accounting fraud, have more informative financial statements and higher quality audits, and are subject to fewer SEC enforcement actions and shareholder lawsuits. ${ }^{88}$ Though the results of studies on the relationship between earnings restatements and board independence are mixed, the strong weight of the evidence is that higher levels of board independence are associated with more accurate financial reporting. ${ }^{89}$ Researchers studying the relationship between audit committee independence specifically and financial reporting quality find similar results. ${ }^{90}$

shareholders in takeover situations, including studies finding an association between board independence and larger abnormal returns in management buyouts and an association between bidder firm board independence and abnormal returns surrounding takeover announcement.

83 Id. at $1866-67$.

84 Id. at 1868.

85 Id. at 1869.

86 Id.

87 Id.

88 Id. at $1870-71$.

89 Id. at 1871.

$90 I d$. at $1872-73$. Note that there is some overlap between the studies that Professors Prentice and Spence cite and those noted by Professor Romano that indicate a relationship between audit committee independence and financial reporting. See supra text accompanying note 55 . 
Though the data are mixed, much of the available empirical evidence does cast substantial doubt on the idea that internal governance mechanisms such as independent boards improve firm performance. Some scholars have suggested reasons for why board independence may lack empirical support. For example, Professor Jeff Gordon notes that the benefits of director independence are systemic and do not necessarily accrue to firms on an individual basis. ${ }^{91}$ Independent boards, he argues, lead to a culture of better corporate governance, more reliable financial reporting, and less accounting fraud, which benefits the market and society as a whole. ${ }^{92}$ Such systemic benefits would not show up in cross-sectional studies of firms. ${ }^{93}$ Therefore, an absence of evidence with respect to the benefits of board independence does not mean that there are no benefits. Professor Gordon also offers another potential explanation: U.S. corporate governance is so good that marginal improvements in any particular governance mechanism are likely to have small, if not negligible, effects on firm performance. ${ }^{94}$

Professor Jill Fisch offers the following perspective: boards have evolved from "advisory boards" that primarily counseled management on corporate strategy to "monitoring boards" that evaluate managerial performance and attempt to deter managerial impropriety. ${ }^{95}$ Professor Fisch argues that since monitoring boards "do not offer corporations strategic advice, operational analysis or other types of managerial support . . . large-scale empirical studies are unlikely to find a link between board monitoring and firm performance." 96 The primary benefit of monitoring boards is the ability to prevent managerial wrongdoing such as fraud. Yet, assessing the deterrent value of a monitoring board is

$91 \quad I d$. at 1869.

$92 \mathrm{Id}$.

93 Id.

94 Jeffrey N. Gordon, The Rise of Independent Directors in the United States, 1950-2005: Of Shareholder Value and Stock Market Prices, 59 STAN. L. REV. 1465, 1468 (2007).

95 See id. at 1506.

96 Fisch, supra note 31, at 929. 
difficult, Professor Fisch argues, because one must engage in an "impossible counterfactual analysis": would management have engaged in wrongdoing if not for the board's actions? ${ }^{97}$

Professor Fisch further suggests that, if accurate stock prices enhance market discipline, then perhaps board effectiveness should be measured not by absolute price (i.e., how the board maximizes firm value), but instead by "price quality" (i.e., the accuracy of financial disclosures that lead to informed prices). ${ }^{98}$ This sentiment is consistent with a theory espoused by Professor Gordon, who notes that independent directors can serve a number of purposes, including operating as "friction" in control markets and providing the oversight necessary to yield the public good of more accurate disclosures, thereby leading to more informed stock prices and better allocation of capital. ${ }^{99}$

\section{B. Corporate Governance Ratings}

The story told by the SOX and Dodd-Frank critics is one in which an inept and/or lazy Congress passed governance mandates without stopping to consider the ample empirical evidence that casts substantial doubt on the effectiveness of the enacted provisions. This story is similar to the one told by critics of commercial governance ratings firms, who claim that firms such as ISS peddle voodoo ratings lacking empirical foundation to naïve institutional investors for profit.

Commercial service providers such as ISS and The Corporate Library have developed metrics to assess the strength of corporate governance in public companies. ISS, the leading governance rating agency, will not disclose how the various elements of its rating score, the CGQ, are weighted, but has revealed that the most important variables in generating a firm's CGQ relate to audit committee independence, financial expertise of audit committee members, cost of executive and employee equity

\footnotetext{
$97 \quad I d$.

98 Id. at 932.

99 Gordon, supra note 94, at 1469, 1564.
} 
issuances, board independence generally, director stock ownership requirements, and incorporation in a state with anti-takeover provisions. ${ }^{100}$ Thus, the rating appears to be heavily weighted toward the quality of internal governance.

Professor Paul Rose is a leading critic of corporate governance ratings and laments the use of "rules of thumb" translated into hard metrics by governance ratings firms to judge firms. ${ }^{101}$ He states, "good governance may affect firm performance, but it is not clear that the variables selected by governance ratings agencies are the appropriate metrics to test and promote good firm performance."102 Similarly, Professor Jeffrey Sonnenfeld argues that the factors considered in generating corporate governance ratings are largely the product of "Wall Street superstitions" and "clichés and myths, rather than . . . genuine research." ${ }^{103}$ Professor Sonnenfeld concedes that some of the variables in corporate governance ratings are appropriate. ${ }^{104}$ However, Professor Sonnenfeld says, "ISS . . . blend[s] these dimensions with superstitious ones to create checklists of highly stringent standards, regardless of the genuine research foundation to support them." 105

Professors Lawrence Brown and Marcus Caylor, in a study commissioned by ISS, find that higher corporate governance scores based on ten of fifty-one governance attributes derived from ISS data are associated with relatively higher firm profitability, as measured by return on equity and return on assets. ${ }^{106}$ However, Professors Sanjai

100 Rose, supra note 4, at 900-01. This information is based on the ISS CGQ formula as it stood following the 2006 ratings guideline changes.

101 Id. at 910.

102 Id. at 913.

103 Id. at 910 .

$104 I d$.

$105 I d$.

$106 I d$. at 913. Finding that only ten of the fifty-one attributes are significantly and positively associated with company performance supports the idea that corporate governance ratings can contain a lot of noise (i.e., only a subset of the attributes in the typical ratings indicators have any relationship with firm performance). Id. at 913-14. 
Bhagat and Brian Bolton, using the full set of ISS corporate governance metrics (not the subset used by Professors Brown and Caylor), as well as the governance scores of ISS competitor The Corporate Library, find that these governance ratings are not significantly correlated with either contemporaneous or future firm operating performance, as measured by return on assets. ${ }^{107}$ This evidence calls into question the relationship between corporate governance ratings and firm value.

Other empirical evidence also casts serious doubt on the efficacy of corporate governance indices. For example, Professors Rob Daines, Ian Gow, and David Larcker, after examining corporate ratings produced by ISS, GovernanceMetrics International, and The Corporate Library, find little evidence that commercial corporate governance ratings are particularly useful in predicting future operating performance, future accounting restatements, or future shareholder litigation. ${ }^{108}$ Similarly, Professors Bhagat, Bolton, and Romano, after reviewing governance indices generated by academics and commercial ratings firms, conclude that there is little evidence of any relationship between commercial ratings and firm performance. ${ }^{109}$ As Professor Larcker, who along with

107 Id. at 914. Sanjai Bhagat \& Brian Bolton, Corporate Governance and Firm Performance 5-6 (Apr. 2007) (unpublished manuscript) (on file with Columbia Business Law Review), available at http://citeseerx.ist.psu.edu/viewdoc/download?doi=10.1.1.180.5811\&rep=re p1\&type=pdf, archived at http://perma.cc/H5E6-RXA7. Professors Bhagat and Bolton use fifty-two ISS governance characteristics to construct the governance score used in their analysis. Because Professors Bhagat and Bolton do not list the fifty-two metrics in their paper, it is not possible to know which additional governance characteristic they use in constructing the ISS governance score that is not used by Professors Brown and Caylor. Id. at 38 tbl.1. Recall that Professors Brown and Caylor construct a data set using fifty-one ISS governance attributes. See supra note 106.

108 Robert M. Daines, Ian D. Gow \& David F. Larcker, Rating the Ratings: How Good are Commercial Governance Ratings?, 98 J. FIn. ECON. 439, 440 (2010).

109 Sanjai Bhagat, Brian Bolton \& Roberta Romano, The Promise and Peril of Corporate Governance Indices, 108 CoLUM. L. REV. 1803, 1850-52 (2008). 
Professors Scott Richardson and Irem Tuna, finds no relationship between a variety of corporate governance indicators and firm performance, states, "[1]ots of people are coming up with governance scorecards . . . They're coming up with best practices and selling this stuff. As far as we can tell, there's no evidence that those scorecards map into better corporate performance or better behavior by managers." 110

Professor Rose argues that besides offering an inaccurate assessment of the quality of a firm's corporate governance, rigid governance metrics have a more troubling systemic impact: they serve to standardize governance mechanisms and compel adherence to a fixed set of practices in a context where flexibility would be more desirable. ${ }^{111}$ The proliferation of one-size-fits-all governance scores can stifle potentially beneficial managerial innovation. ${ }^{112}$ Though ISS' governance recommendations are not mandatory as a matter of law, given ISS' influence in the institutional investor community, firms feel compelled to comply, thus leading, Professor Rose argues, to "a more homogenous corporate population."113

\section{The Market for Corporate Control}

Though many members of the academy tend to be skeptical of internal governance mechanisms, external governance mechanisms find broad support among legal scholars. Hostile takeovers, under the conventional wisdom, serve to discipline management and lead to higher shareholder value. Poor firm performance leads to a lower stock price, which makes it attractive for better management to take over a company and, in turn, improve operations and increase firm value. Given the benefits derived from hostile takeovers, Professor Jonathan Macey argues that regulators have it exactly backwards-the governance devices that are most ineffective are championed, while the mechanisms most

\footnotetext{
110 Rose, supra note 4, at 913.

111 Id. at 917.

112 Id. at 918-19.

113 Id.
} 
likely to improve firm performance attract regulatory attention. ${ }^{114}$ In particular, he points to "ineffective" boards of directors and argues that they enjoy "regulatory subsidies," 115 while the "effective" market for corporate control has been hamstrung by "protectionist legislation" and court decisions that allow target firm managers to thwart the efforts of hostile bidders and "escape the discipline of a hostile takeover."116 Professor Macey's views are consistent with the dominant law and economics view articulated by Judge Frank Easterbrook and Professor Daniel Fischel in the 1980s, who advocated managerial passivity in the face of hostile bids because of what they viewed as the clear benefits stemming from takeovers. ${ }^{117}$ Even Professor Rose, who expresses grave concerns about the potential for homogenization in corporate governance as a result of corporate governance ratings, concludes that a potentially beneficial side effect of the governance ratings industry is its effect on the market for corporate control, given the governance industry's stance against antitakeover devices. ${ }^{118}$

Here, the empirical evidence is seemingly clear: target shareholders historically have enjoyed substantial gains from takeovers. ${ }^{119}$ This is unsurprising; hostile (and friendly) bidders have to offer a premium over the current share price to induce shareholders to sell their shares. The use of effective antitakeover devices can have two potential effects. On the one hand, it can reduce the possibility of a successful takeover, either because the presence of such devices deters hostile bids or because the use of such devices provides a

114 MACEY, supra note 14 , at 48.

115 Id. at 49 .

116 Id. at 46. Professor Macey points to the Williams Act, passed by Congress in 1968, and the judicial sanctioning of the use of poison pills by the Delaware Supreme Court in 1985 as examples of legal impediments to the market for corporate control. Id. at 122, 123.

117 Fisch, supra note 31, at 940.

118 Rose, supra note 4, at 918.

119 Michael Klausner, Fact and Fiction in Corporate Law and Governance, 65 STAN. L. REV. 1325, 1349 (2013). 
means for management to defeat hostile bids. ${ }^{120}$ As a result, because the threat of a hostile takeover purportedly serves to discipline management, having defenses available diminishes the disciplining effect substantially and removes the pressure on management to maximize shareholder value, even in the absence of a pending bid. ${ }^{121}$ On the other hand, antitakeover devices have the potential to maximize shareholder value, as managers can use takeover defenses either to give them negotiating leverage with a hostile bidder, leading to higher sale prices, or to ward off bids that undervalue the target. ${ }^{122}$ Thus, takeover defenses can be either value enhancing or value reducing. ${ }^{123}$

Other than dual-class stock, a structure that is rarely employed, ${ }^{124}$ the combination of a poison pill and an "effective staggered board" 125 is the most potent takeover defense available. ${ }^{126}$ Poison pills are considered lethal, hence the name. The significant voting and economic dilution a hostile bidder suffers by triggering a poison pill (by crossing a pre-determined threshold of ownership, such as $15 \%$, without the approval of the target board) serves as a highly

120 Id. at 1349.

$121 \mathrm{Id}$.

$122 I d$.

$123 \mathrm{Id}$.

124 Id. at 1353.

125 An "effective" staggered board is a staggered board whose potency cannot be diminished by: (1) stockholder ability to dismantle the staggered board unilaterally and easily by amending the company's bylaws with a majority vote, (2) stockholder ability to pack the board with new directors, thereby creating a new majority, or (3) stockholder ability to remove directors without cause. $I d$. at 1353 n.110. In Delaware, the default rule is that directors on a staggered board may only be removed for cause. See Del Code Ann. Tit. 8, § 141(k)(1) (2014). However, a company's charter may provide for removal without cause. A company with such a charter provision does not have an effective staggered board. See, e.g., the staggered board of Airgas, Inc. Air Products \& Chemicals, Inc. v. Airgas, Inc., 16 A.3d 48, 116 (Del. Ch. 2011) ("Airgas's charter allows for 33\% of the outstanding shares to call a special meeting of the stockholders, and to remove the entire [classified] board without cause by a vote of $67 \%$ of the outstanding shares.”).

126 Klausner, supra note 119, at 1365-66. 
effective deterrent for unfriendly takeovers. Corporate boards can unilaterally (i.e., without shareholder approval) adopt a poison pill at any time, and many firms wait until a hostile bid appears before putting a pill in place. A study of hostile takeover attempts performed by Professors Bebchuk, John Coates, and Guhan Subramanian revealed that every target either had a pre-existing pill in place or adopted a pill once a hostile bid was made. ${ }^{127}$ Thus, every company has a "shadow pill."

It is fair to say, therefore, that the most important takeover defense is the presence of an effective staggered board. ${ }^{128}$ Courts have the power to force a company to redeem a pill but are unlikely to do so. Indeed, the Delaware Supreme Court has never ordered a company's board to redeem its poison pill. Poison pills, however, can be redeemed by a board of directors voluntarily. Therefore, as a practical matter, in order to have the poison pill redeemed, a hostile suitor must either convince the board to support the takeover (thus, turning a hostile bid into a friendly deal) or take control of the board by electing directors, via a proxy contest, who will vote to redeem the poison pill once they take office. Proxy contests, however, are a less viable strategy for hostile bidders facing targets with staggered boards.

In a classified or staggered board, not all directors are up for re-election annually. Rather, director terms are staggered, generally providing for only one-third of the directors to seek re-election in any given year. Therefore, even if the hostile bidder could convince the target's shareholders to vote in favor of its director nominees, it would take two election cycles (or as long as two years) before the hostile bidder could seize control of the target's board and have the pill removed. This delay imposes costs and uncertainty, so it is an unappealing prospect for a hostile bidder. Staggered boards present a nearly insurmountable

127 Lucian Arye Bebchuk, John C. Coates IV \& Guhan Subramanian, The Powerful Antitakeover Force of Staggered Boards: Theory, Evidence, \& Policy, 54 StAN. L. REV. 887, 926-27 (2002).

128 See Klausner, supra note 119, at 1366. 
hurdle to hostile takeover success. No hostile bid has ever succeeded in the face of an effective staggered board and a pill. ${ }^{129}$ Thus, arguably, no other defensive mechanisms (e.g., stockholder inability to call a special meeting or to act via written consent) matter much at the margin for a firm with an effective staggered board. ${ }^{130}$

The evidence on the effect of staggered boards is seemingly clear. Professors Bebchuk, Coates, and Subramanian find evidence consistent with the claim that staggered boards decrease shareholder value. Specifically, they find that companies with staggered boards are more likely to remain independent in the face of a takeover battle ${ }^{131}$ and that staying independent leads to lower value for shareholders, relative to those firms that are acquired. ${ }^{132}$ The researchers also find no statistically significant difference between the premiums commanded by acquisition targets with staggered boards and those targets without staggered boards, ${ }^{133}$ which casts doubt on the claim that staggered boards increase target bargaining leverage in a way that can be value enhancing. The researchers, overall, find an average loss of share value of $8-10 \%$ for firms with staggered boards. ${ }^{134}$

Similarly, Professors Bebchuk and Alma Cohen find that companies with staggered boards have lower firm value than

129 In a study of bids during the five-year period of 1996-2000, Professors Bebchuk, Coates, and Subramanian find that no hostile bidder successfully gained control of a board of a company with an effective staggered board through winning director elections. Bebchuk et. al., supra note 127 , at 890 . They also find that, because threats of a hostile takeover against an effective staggered board lack credibility given how difficult it is to seize control of the board, effective staggered boards make it easier for targets to remain independent. Their study shows that the presence of an effective staggered board almost doubles the likelihood of remaining independent from $34 \%$ to $61 \%$. Id. at 890-91.

130 For firms without effective staggered boards, these mechanisms, of course, can have an important effect. Klausner, supra note 119, at 1366 .

131 See supra note 129 and accompanying text.

132 Klausner, supra note 119 , at 1354.

133 Id.

134 Id 
firms with directors who stand for annual election. ${ }^{135}$ Professors Cohen and Charles Wang find evidence consistent with the claim that the relationship between staggered boards and firm value is a causal one (i.e., staggered boards lead to reductions in firm value as opposed to the reverse causal story that firms with low values opt for the protection afforded by staggered boards). ${ }^{136}$ Also, consistent with evidence of staggered boards as "value destroyers," Professors Re-Jin Guo, Timothy Kruse, and Tom Nohel find that announcements of board declassifications yield small but statistically significant positive abnormal returns. ${ }^{137}$

There also is extensive empirical evidence that suggests that other external governance mechanisms are value enhancing. The G-Index and the E-Index are two leading measures of managerial entrenchment and vulnerability to takeover. The G-Index, created by Professors Paul Gompers, Joy Ishii, and Andrew Metrick, consists of twenty-four metrics designed to measure the balance of power between the board and shareholders and the ease by which directors can be replaced via hostile takeover or proxy contest. ${ }^{138}$ Professors Gompers, Ishii, and Metrick find that from 19901999 firms with G-Index scores in the lowest decile (those with the highest exposure to the market for corporate control) enjoy higher value and better performance than firms with G-Index scores in the highest decile (those with the lowest exposure to the market for corporate control). ${ }^{139}$

$135 I d$.

136 Alma Cohen \& Charles C.Y. Wang, How Do Staggered Boards Affect Shareholder Value? Evidence from a Natural Experiment, J. FIN. ECON. (forthcoming 2013) (manuscript at 3-4), available at http://papers.ssrn.com/sol3/papers.cfm?abstract_id=2141410, archived at http://perma.cc/6XVX-WJA7, cited in Klausner, supra note 119, at 1355.

137 Re-Jin Guo et al., Activism and the Shift to Annual Director Elections, J. Acct. \& Fin. (forthcoming) (manuscript at 20), cited in Klausner, supra note 119, at 1361.

138 Klausner, supra note 119, at 1363-64.

139 Id. at 1364 . More recently, this ability to earn abnormal returns is disappearing as investors learn how to differentiate between firms that score well or poorly on governance metrics. See Lucian A. Bebchuk et al., 
Hundreds of articles using the G-Index as a proxy for governance quality have appeared in the academic literature, ${ }^{140}$ and an analysis of firm differences in accordance with the G-Index reveals that firms with weaker shareholder rights have lower profits, sales growth, and value. ${ }^{141}$

The E-Index, created by Professors Bebchuk, Cohen, and Allen Ferrell, consists of six characteristics related to managerial entrenchment. ${ }^{142}$ The researchers identified these six metrics from among the twenty-four metrics in the G-Index that are associated with firm value as measured by Tobin's Q. ${ }^{143}$ Professors Bebchuk, Cohen, and Ferrell find that greater board entrenchment, as measured by the EIndex, is associated not only with lower firm values, as measured by Tobin's Q, ${ }^{144}$ but also with lower returns. ${ }^{145}$ Another study by Professors Bebchuk, Cohen, and Wang finds a relationship between high E-Index (managerial entrenchment) and lower firm value, profitability, and sales

Learning and the Disappearing Association Between Governance and Returns, 108 J. FIN. ECON. 323, 324 (2013).

140 A Scopus search reveals that as of November 26, 2014, 1,471 articles have cited the Gompers et al. study. Scopus Search on Gompers Study, Scopus, www.scopus.com/home.url (search "Corporate Governance and Equity Prices"; then select "Corporate governance and equity prices" hyperlink by Gompers, Ishii, Metrick). Though this does not mean that all such articles use the G-Index as a variable in analyses, it is reasonable to assume that a large number do.

141 Lucian A. Bebchuk, The Myth that Insulating Boards Serves LongTerm Value, 113 CoLuM. L. REV. 1637, 1685 (2013).

142 Lucian Bebchuk, Alma Cohen \& Allen Ferrell, What Matters in Corporate Governance?, 22 REV. FIn. STUD. 783, 785 (2009).

$143 I d$. at 784-785. Elements include staggered boards, limits to shareholder amendments of the bylaws, supermajority requirements for mergers and for charter amendments, poison pills, and golden parachutes.

144 Tobin's Q is defined by the researchers as "the market value of assets divided by the book value of assets, where the market value of assets is computed as the book value of assets plus the market value of common stock less the sum of book value of common stock and balance sheet deferred taxes." Id. at 800 .

145 Id. at 786. 
growth. ${ }^{146}$ The E-Index is a popular metric and has been used in 158 studies since its introduction in $2004 .{ }^{147}$

Though the G-Index is a widely used metric in academic research, Professor Michael Klausner argues that the emphasis on the G-Index is misplaced. As Professor Klausner points out, only some of the elements of the index can be used for managerial entrenchment, while others can be used only in limited circumstances for that purpose. ${ }^{148}$ Professor Klausner argues that many elements in the G-Index "have (1) no impact on management entrenchment, (2) no impact on entrenchment if a firm has an effective staggered board, (3) an impact on entrenchment only under limited circumstances, or (4) no relevance to entrenchment and in fact affirmatively beneficial impacts on governance." ${ }^{149}$ Thus, the index "contain[s] unnecessary noise" and introduces the potential for finding a "correlation with no potential causation." 150

Professor Klausner further argues that the counting of takeover defenses reflects a pervasive misunderstanding in the finance literature. More devices does not equal more entrenchment; thus, counting the number of takeover devices a company employs provides no information about that firm's exposure to the market for corporate control or any other aspect of the firm's governance. ${ }^{151}$ Professor Klausner further criticizes the G-Index for giving equal weight to all of the elements in the index, when, if they have any effect on

146 See Bebchuk et al., supra note 139, at 341-43, cited in Bebchuk, supra note 141, at 1686.

147 Based on articles appearing on SSRN. Links to 158 Studies Available on SSRN that Use the Entrenchment Index (Bebchuk, Cohen, and Ferrell, 2009), LUCIAN AYRE BEBCHUK, http://www.law.harvard.edu/ faculty/bebchuk/studies.shtml, archived at http://perma.cc/E642-C6MG (last updated Nov. 2014), cited in Klausner, supra note 119, at 1363 n.155.

148 Klausner, supra note 119 , at 1363.

149 Id. at 1364. Elements in the G-Index widely seen as beneficial include: "director indemnification provided for in bylaws, director indemnification provided by agreement, and protection of outside directors from monetary liability for violation of the duty of care." Id. at 1367.

150 Id. at 1363.

151 Id. at 1365 . 
entrenchment, they do so at varying levels. ${ }^{152}$ Given the empirical support for the relationship between the G-Index and firm performance, Professor Klausner concedes that the G-Index must be "measuring something," but finds it implausible that the "something" is the level of managerial entrenchment ${ }^{153}$ or quality of external governance. He also argues that the E-Index, another metric that, as noted above, is widely used in the academic literature, suffers from the same flaws as the G-Index.

Despite Professor Klausner's skepticism of the measures of external governance typically used in academic studies, the weight of empirical evidence supports the value of high-quality external governance. However, some scholars point to the limitations of the market for corporate control and note that not all takeovers are efficient. The heyday of the hostile takeover was in the 1980s, as the idea of creating shareholder value became highly influential in the business community. ${ }^{154}$ As Professor Gordon describes, however, the 1980s also saw its share of high-profile hostile takeover failures, which damaged the credibility of the practice. ${ }^{155}$ After the 1980s came the realization that hostile takeovers were a high-cost way to minimize managerial agency costs. ${ }^{156}$

In addition, there are limits to the effectiveness of the market for corporate control as a disciplining device. Some companies are simply too big to buy. ${ }^{157}$ Other companies are too small to be worth the effort required of a hostile bid because takeovers are costly. The need for financing requires favorable credit market conditions. ${ }^{158}$ Also, the high transaction costs associated with hostile bids means that they are only pursued in situations where there is significant perceived managerial underperformance. ${ }^{159}$ This

\footnotetext{
152 Id. at 1364.

$153 I d$.

154 Gordon, supra note 94, at 1527.

$155 I d$.

156 Id.

157 Fisch, supra note 31, at 940-42.

158 Id. at 942.

159 Gordon, supra note 94, at 1528.
} 
"lumpiness," in turn, reduces deterrence. ${ }^{160}$ Also, hostile takeovers are likely to occur only if a company appears to be undervalued. If a firm's stock price is too high, whether because of an overheated stock market or accounting fraud, the market for corporate control offers no solution. ${ }^{161}$

The market for corporate control also has the potential to be overinclusive, leading to inefficient takeovers. Specifically, takeovers have the potential to take advantage of temporary dips in target share prices, and shareholder collective action problems can make it difficult for target shareholders to identify these situations. ${ }^{162}$ Professors Andrei Shleifer and Robert Vishny suggest that misvaluation of target firms, not potential synergy, drives most takeover activity. ${ }^{163}$ Professors Ming Dong, David Hirshleifer, Scott Richardson, and Siew Hong Teoh suggest that bidders may expropriate value from target shareholders either by buying targets for cash at prices below intrinsic value or by using their overvalued stock as acquisition currency. ${ }^{164}$

De-staggering boards, in particular, can be inefficient. Although moving to annual director elections may better discipline managers, further exposing them to the market for corporate control, annual elections could also be adverse to the interests of large institutional investors. ${ }^{165}$ For example, annual director elections are beneficial to activist hedge funds seeking to replace directors with those sympathetic to their efforts to, say, initiate a sale of the company to a third party. ${ }^{166}$ The short-term focus of some hedge funds, however, could be at odds with the interests of stockholders with a long-term perspective. ${ }^{167}$

One empirical study provides evidence that antitakeover devices can improve shareholder value. Though takeover

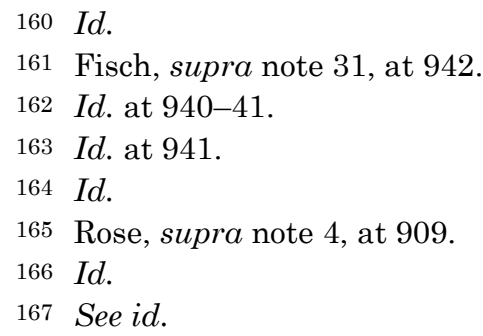


defenses are generally believed to be value reducing, Professors William Johnson, Jonathan Karpoff, and Sangho Yi find evidence that firms with substantial contractual commitments to customers, suppliers, and strategic partners commonly go public with takeover defenses, and that these defenses increase share value. ${ }^{168}$ For these firms, takeover defenses can be value enhancing because they provide some reassurance to the firm's partners that the company will maintain these relationships, thereby encouraging those partners to invest in the relationships. ${ }^{169}$

Another recent study also calls into question the claim that classified boards destroy shareholder value. ${ }^{170}$ Using Tobin's Q as a proxy for firm value, for the period 1978-2011, Professors Martijn Cremers, Lubomir Litov, and Simone Sepe find in the cross-section, consistent with the prior literature, that firms with staggered boards have lower values. ${ }^{171}$ However, they find the opposite result when viewing the data in the time series (panel data regression), as board de-staggering is associated with declining value and moving from annual director elections to a classified board

168 William C. Johnson et al., The Bonding Hypothesis of Takeover Defenses: Evidence from IPO Firms 29 (Sept. 22, 2014) (unpublished manuscript), available at http://papers.ssrn.com/sol3/papers.cfm? abstract_id=1923667, archived at http://perma.cc/4P2G-7XBM, cited in Klausner, supra note 119, at 1334-35.

169 Klausner, supra note 119, at 1335.

170 Liz Hoffman, Staggered Boards May Boost Returns: Study, WALL ST. J. (Dec. 11, 2013, 4:52 PM), http://blogs.wsj.com/moneybeat/ 2013/12/11/staggered-boards-may-boost-returns-study/, archived at http://perma.cc/2FWV-5J7D (citing K.J. Martijn Cremers, Lubomir P. Litov \& Simone M. Sepe, Staggered Boards and Firm Value, Revisited 3-4 (July 2014) (unpublished manuscript), available at http://papers.ssrn.com/sol3/papers.cfm?abstract_id=2364165\&download=ye $\mathrm{s}$, archived at http://perma.cc/38RB-AKRT).

171 K.J. Martijn Cremers, Lubomir P. Litov \& Simone M. Sepe, Staggered Boards and Firm Value, Revisited 4-5 (July 2014) (unpublished manuscript), available at http://papers.ssrn.com/sol3/papers.cfm? abstract_id=2364165\&download=yes, archived at http://perma.cc/38RBAKRT. 
structure with increasing value. ${ }^{172}$ To help explain their novel results, they test the assertion that staggered boards actually may be advantageous for companies because they commit shareholders and boards to longer-term horizons. As support for this hypothesis, their study reveals that the association between higher firm value and adopting a staggered board is significantly stronger for firms that: (1) have higher R\&D expenditures; (2) have more patents and hence are more successful at innovation; (3) have more intangible assets; and (4) are larger and presumably more complex. ${ }^{173}$ Therefore, as the researchers argue, staggered boards, which can allow for more managerial stability and continuity, may "offer an "institutional memory" that prevents rapid changes in a firm's business strategy in response to short-term demands from the market. ${ }^{174}$ The results of this study are consistent with those of Professors Larcker, Gaizka Ormazabal, and Daniel Taylor-who find negative stock market reactions following proposals to eliminate staggered boards ${ }^{175}$ - and consistent with the literature that suggests classified boards can provide value-

172 Id. Employing panel data regression analysis allows the researchers to control for firm-specific, time-invariant factors that may affect firm value. Using tools such as firm fixed effects removes any purely cross-sectional (i.e., across firm) correlation between board type (e.g., staggered or unitary board) and firm value, thus greatly reducing the risk the correlation a researcher finds between those variables is spurious. Panel data regression analysis with firm-level fixed effects allows a researcher to answer whether, for any firm in the sample, the firm's value increases or decreases as the firm's board type changes over time. In other words, in firm-level fixed effects models, the researchers are comparing changes in board type over time with changes in firm value over time within individual firms, instead of across firms. The underlying premise for this analysis is that if the unobserved firm characteristics do not change over time (i.e., are time-invariant), then any changes the researchers observe in firm value over the study period are the result of influences other than (fixed) omitted variables.

173 Id. at 7.

174 Id. at 8.

175 See David F. Larcker, Gaizka Ormazabal \& Daniel J. Taylor, The Market Reaction to Corporate Governance Regulation, 101 J. Fin. ECON. 431, 433 (2011). 
enhancing continuity and stability. ${ }^{176}$ This suggests that the empirical case against staggered boards is not as clear as it was once thought. That said, despite these findings, most of the empirical evidence suggests the lack of exposure to the market for corporate control is value destroying.

\section{RESEARCH OBJECTIVE, DATA, METHODOLOGY AND RESULTS OF ANALYSIS}

\section{A. Research Objective}

My objective is to examine the relationship between institutional ownership and corporate governance in hopes of yielding meaningful insight about institutional investor governance preferences. To this end, I employ ordinary least squares ("OLS") cross-sectional regression analysis and pooled OLS regression analysis. Through these analyses, I will be able to determine how strongly various corporate governance mechanisms are associated with level of institutional ownership.

\section{B. Data and Sample}

My sample of firms includes all those listed on the New York Stock Exchange ("NYSE")that had common stock trading information in the Center for Research in Security Prices ("CRSP") database ${ }^{177}$ for which data was available for the variables used in this study. My sample size ranges from 618 to 909 firms, depending on specification.

The Thomson Financial institutional holdings database is the source of institutional ownership data, both overall and for institutional ownership by type. The Thomson Financial

176 Cremers et al., supra note 171 , at 8 (citing Stephen A. Ross, RANDOlPh W. Westerfield \& Bradford D. Jordan, Fundamentals of Corporate Finance (1991)); Richard H. Koppes, Lyle G. Ganske \& Charles T. Haag, Corporate Governance Out of Focus: The Debate over Classified Boards, 54 Bus. LAW. 1023, 1055 (1999).

177 See Alicia J. Davis, Market Efficiency and the Problem of Retail Flight, 20 STAN. J. L. BUS. \& Fin. 36, 59 (2014), for a discussion of sample construction. 
S34 database provides five classifications of institutional investors: (1) banks; (2) insurance companies; (3) investment companies; (4) independent investment advisors; and (5) corporate (private) pension funds, public pension funds, university and foundation endowments; and miscellaneous. However, the S34 database's type classifications for years after 1998, per Thomson Financial, are not reliable. Therefore, I use Professor Brian Bushee's classifications, supplemented by my own research when necessary to fill in missing information, to classify the institutional investors in this study. ${ }^{178}$ Professor Bushee divides institutional investors into eight categories: (1) banks; (2) insurance companies; (3) investment companies; (4) independent investment advisors; (5) corporate (private) pension funds; (6) public pension funds; (7) university and foundation endowments; and (8) miscellaneous. ${ }^{179}$ In my analysis, I combine investment companies and independent investment advisors into one group-investment companies or "mutual funds"-and maintain all other Bushee classifications.

Information on stock prices, outstanding shares, and trading volume is from the CRSP database, and the merged CRSP-Compustat database is the source of accounting data. I obtained research coverage and activity data from the First Call (Thomson Financial) database, and news coverage data from ProQuest Newsstand articles. Thomson Financial is the source of industry Standard Industrial Classification ("SIC") codes. I obtained data on S\&P 500 composition from Compustat's Index Constituents database.

I obtained Index and Industry CGQs and governance data from ISS; the E-Index for the years 2002-2006 from

178 I am grateful to Professor Bushee for sharing his classification database. Institutional Investor Classification Data (1981-2009), WHARTON UNIVERSITY OF PENNSYLVANIA, http://acct.wharton.upenn.edu/faculty/ bushee/, archived at http://perma.cc/3E2F-ZTFU (last updated July 15, 2010).

179 Institutional Investor Classification Data: Variable Definitions, WHARTON UNIVERSITY OF PENNSYLVANIA, http://acct.wharton.upenn.edu/ faculty/bushee/IIvars.html, archived at http://perma.cc/86XS-S86W (last updated June 10, 2014). 
Professor Lucian Bebchuk's website and for years 2007-2010 through calculations derived from information in the RiskMetrics database; the G-Index for 2002-2007 from the RiskMetrics database; data on Delaware incorporation from the RiskMetrics database; and data on total restatement history and "irregularity" restatement history through June 30, 2006, from Professor Andrew Leones' website. ${ }^{180}$ Information on restatements after June 30, 2006, was hand collected from securities filings (appearing primarily on Form 8-K) and news reports.

\section{Empirical Methodology and Results of Analysis}

\section{2010 OLS Regression}

My OLS regression analysis uses March 31, 2010, the last quarter end in which the ISS CGQ was in use, as the date of interest. The dependent variable in my analysis is institutional ownership (INSTOWN) ${ }^{181}$ (calculated as the number of shares of a firm's stock held by institutions divided by the total number of shares outstanding), as of March 31, 2010. I have seven independent variables of interest. The first three variables relate to the quality of

180 See Andy Leone's Home Page, University of Miami - School of Business, http://sbaleone.bus.miami.edu, archived at http://perma.cc/ K7LC-TPEQ (last visited Mar. 15, 2014) (containing link to GAO Restatement Data).

181 Because of duplicative reporting by institutions on the required Form 13-Fs (all institutions with $\$ 100$ million dollars or more in securities under discretionary management are required to report their holdings to the SEC each quarter), some firms in the study sample have institutional ownership percentage values that, as calculated, exceed 100\%. Other researchers find that such instances of duplicative reporting are generally rare, and, thus, the figures, though anomalous, should not bias this study's results significantly. See, e.g., Anjan V. Thakor, JefFrey S. NiElsen \& David A. Gulley, The Economic Reality of Securities Class Action LitigATION app. I, at 2. (2005). Also, note that the institutional ownership variable only represents stock owned by large institutions (that is, those with $\$ 100$ million or more in assets under management). Given data limitations, it is not possible to know precisely what proportion of "noninstitutional ownership" is ownership by individual investors rather than small institutional investors. 
internal governance, either primarily or exclusively. The last four variables relate to the quality of external governance.

The first independent variable of interest is the March 31, 2010, ISS Index CGQ (INDEXCGQ). ${ }^{182}$ Historically, ISS used public disclosures to gather firm-specific data on sixty-one different factors in eight different categories: ${ }^{183}$ (1) board of directors; (2) audit; (3) charter and bylaw provisions; (4) antitakeover provisions; (5) executive and director compensation; (6) progressive practices; (7) ownership; and (8) director education. ${ }^{184}$ ISS then developed a CGQ for each company based on scores achieved on these variables by comparing each firm with the other firms in its peer market (e.g., the S\&P 500, Russell 3000). For example, an S\&P 500 company with an Index CGQ of 82 has achieved a higher governance score than $82 \%$ of the firms in the S\&P 500 . Thus, firms with the highest scores are considered to have the highest quality corporate governance. As discussed previously, though ISS does not reveal publicly the weights underlying each factor in the final index score, it is reasonable to conclude that internal governance factors are more heavily weighted than external governance factors. Six of the eight categories and forty-one of the sixty-one factors relate only to internal governance matters: (1) board of directors (excluding the absence of a staggered board, which is important in contests for corporate control); (2) audit; (5)

182 CGQ data was first published on September 30, 2002 (outside of publication in a pilot program on December 31, 2001). As of December 31, 2009, ISS no longer updated the CGQ scores as it transitioned to a new governance rating scale. However, that new scale was not put into place until June 2010. Thus, available information from ISS on corporate governance scores on March 31, 2010, was based on information updated on December 31, 2009.

183 See infra Appendix A for a list of these factors. Appendix A contains the pre-2006 factors. CGQ scores before 2006 were based on sixtyone factors. The 2006 CGQ scores were based on sixty-eight factors, and the 2007-2010 CGQ scores were based on sixty-six factors. infra Appendix A.

184 Some variables are also evaluated in combination because ISS believes governance is enhanced by the presence of certain clusters of governance characteristics and practices. 
executive and director compensation; (6) progressive practices; (7) ownership; and (8) director education (factors 1-4, 6-21, and 41-61). Also, as discussed in Part II.B, five of the six most heavily weighted elements in the CGQ relate to internal governance.

The second independent variable of interest is ISS' Industry CGQ (INDUSCGQ). The Industry CGQ reflects a firm's performance in corporate governance vis-a-vis its industry peers. Again, higher Industry CGQs imply better governance.

The third independent variable of interest is a variable I created that assigns one point for each component of the INDEXCGQ that is related to what I characterize as internal governance (ISSINTERNAL). ${ }^{185}$ Firms with more purportedly high-quality internal governance mechanisms have higher ISSINTERNAL scores. Professor Klausner's caution on simply counting governance mechanisms ${ }^{186}$ is well-taken. However, since I am measuring investor preferences for particular types of mechanisms and not using the metric to make claims about the quality of governance, I believe the use of this variable is appropriate.

The fourth independent variable of interest is the Bebchuk, Cohen, and Ferrell E-Index score (EINDEX). As described in Part II.C, this popular external governance metric assigns points to antitakeover defenses used by firms (e.g., poison pill, classified board). ${ }^{187} \mathrm{~A}$ maximum of six points is available. Under this rating system, firms with the lowest scores are considered to have the best external governance structure.

The fifth independent variable of interest is the Gompers, Ishii, and Metrick G-Index score (GINDEX). As described in Part II.C, this well-known metric assigns points to firms for each characteristic that reduces the level of "shareholder rights." These rights are typically associated with

185 See infra Appendix B for a list of these components.

186 See supra note 149 and accompanying text.

187 See infra Appendix C. 
antitakeover provisions. ${ }^{188}$ Thus, firms with a higher level of shareholder rights are, under this theory, the most disciplined because they are the ones that are most exposed to the market for corporate control. As with the EINDEX, low scores are purportedly indicative of high-quality external governance.

The sixth independent variable of interest is a variable I created that assigns one point for each component of the INDEXCGQ that is related to what I characterize as external governance (ISSEXTERNAL). ${ }^{189}$ Firms with purportedly high-quality external governance have higher ISSEXTERNAL scores.

The seventh independent variable of interest relates to the presence of a classified or staggered board (ANNDIRELEC), represented by a dummy variable equal to 1 if the firm has annual director elections (no staggered board) or 0 if the firm does not have annual director elections. As discussed in Part II.C, the absence of a staggered board is generally considered a sign of high-quality external governance.

I also control for a number of factors that can affect institutional investor ownership. The first control variable is Delaware incorporation (DEINC), represented by a dummy variable equal to 1 if the firm is incorporated in the state of Delaware or 0 if the firm is not. There is evidence that suggests Delaware law is value enhancing. ${ }^{190}$ Implicit in this finding is that Delaware law is superior and accords with sophisticated investor preferences. In addition, in a sample of California-based firms re-incorporating in Delaware, Professors Murali Jagannathan and Adam Pritchard find that incorporation in Delaware is associated with higher institutional ownership. ${ }^{191}$ Professors Jagannathan and

188 See infra Appendix D.

189 See infra Appendix E for a list of these components.

190 See Robert Daines, Does Delaware Law Improve Firm Value?, 62 J. Fin. ECON. 525, 527 (2001).

191 Murali Jagannathan \& A.C. Pritchard, Do Delaware CEOs Get Fired? 21-22 (June 2013) (unpublished manuscript), available at 
Pritchard suggest that this finding means that firms incorporated in Delaware are more likely to attract institutional investors. ${ }^{192}$

The second control variable is the incidence of an accounting restatement due to irregularities (IRRREST) in the one-year period prior to March 31, 2010, represented by a dummy variable equal to 1 if the firm has restated its financial reports because of misconduct during this period or 0 if the firm has not. Professors Karen Hennes, Andrew Leone, and Brian Miller define a restatement involving an irregularity as one in which (1) the firm itself describes its restatement using the words "fraud" or "irregularity," (2) there is a related SEC or Department of Justice investigation, or (3) there is a related independent investigation (e.g., by an independent forensic accounting firm). Prior research suggests that the presence of these factors is indicative of a higher likelihood of misconduct rather than unintentional errors. ${ }^{193}$ I employ this control variable because there is evidence of a relationship between restatements and institutional ownership. For example, Professors Natasha Burns, Simi Kedia, and Marc Lipson find that institutional ownership is positively associated with the

http://papers.ssrn.com/sol3/papers.cfm?abstract_id=1313274, archived at http://perma.cc/Q58U-Z5G5.

192 Id.

193 Professors Hennes, Leone, and Miller acknowledge the possibility for misclassification (e.g., the possibility that there are irregularities that firms do not describe as such or for which no SEC or independent investigation is conducted or the possibility that there are SEC or independent investigations conducted that conclude no deliberate misconduct occurred), but assert that they believe such misclassifications are rare. Karen M. Hennes, Andrew J. Leone \& Brian P. Miller, The Importance of Distinguishing Errors from Irregularities in Restatement Research: The Case of Restatements and CEO/CFO Turnover, 83 ACCT. REV. 1487, 1489 (2008), cited in Natasha Burns et al., Institutional Ownership and Monitoring: Evidence from Financial Reporting, $16 \mathrm{~J}$. CORP. Fin. 443, 444 (2010). Because, in untabulated results, I use both the entire population of restatements and the narrowe $r$ subset of irregularity restatements and get virtually the same results qualitatively, potential misclassifications are of limited importance to this study's overall conclusions. 
likelihood of a firm misreporting its earnings and the magnitude of the misreporting. ${ }^{194}$ The researchers attribute this effect to: (1) the presence of institutional investors with short investment time horizons that fail to engage in effective corporate monitoring; ${ }^{195}$ and (2) managers being under greater pressure to manage earnings (i.e., smooth earnings, perhaps to an extent requiring misstatement) to satisfy demanding, transient investors that will quickly sell their stock in the face of underperformance. ${ }^{196}$

Control variables furthermore include market capitalization as of March 31, 2010 (SIZE), and average daily trading volume during the one-year period prior to March 31, 2010 (VOL), because larger, more liquid firms are more likely to attract institutional shareholder interest. ${ }^{197} \mathrm{I}$ also control for the influence of research analysts on institutional investor investment decisions with two variables: (1) research coverage, defined as the number of analysts that publish earnings estimates on a firm during the one-year period prior to March 31, 2010 (RESCOV); and (2) research activity, defined as the number of published earnings estimates for a firm during the one-year period prior to March 31, 2010 (RESACT).

194 Burns et al., supra note 193, at 444.

$195 I d$. The effect is mitigated, however, by ownership concentration by such institutions. Large ownership stakes provide more incentive to monitor. Id

196 Id. at 452. Burns et al. also consider, but then dismiss, the possibility that institutional ownership is positively associated with restatements because (1) institutions can facilitate the discovery of financial improprieties leading to restatement announcements, or (2) institutions are attracted to "momentum" stocks with managers who have a tendency to engage in aggressive accounting practices. Id. at 454 .

197 See Alicia Davis Evans, A Requiem for the Retail Investor?, 95 VA. L. REV. 1105, 1117 (2009) ("Almost all large institutional investors are confined to making investments in large cap corporations. Either their own charters or government regulations limit their ability to buy stock in small companies because of minimum size and maximum ownership requirements. Moreover, most small cap stocks have thin floats, so any attempt to buy a significant number of shares in a small cap company could move the price of that stock higher instantly, making such investment no longer attractive."). 
I control for company diversity (DIVERSE), which I calculate as the number of industries (determined by fourdigit SIC code) in which the firm operates, because diversified conglomerates may be less attractive investments for individual investors due to the greater difficulty in understanding and valuing the businesses of such firms.

I use firm news coverage (NEWSCOV) as another control variable because Professors Brad Barber and Terrance Odean find that retail investors are attracted to attentiongrabbing stocks, which include those with significant press coverage. ${ }^{198}$ News coverage data were obtained by hand counting the number of days during the one-year period prior to March 31, 2010, on which a firm was featured prominently (i.e., its name appears either in the headline or lead paragraph) in a ProQuest news story. Using number of days of coverage instead of total number of news stories avoids the counting of virtually identical stories that may appear in the news on the same day.

I also control for stock price (STKPRC), defined as a firm's stock price as of March 31, 2010, because cost concerns and a desire to achieve diversification with limited investment funds may lead retail investors to prefer stocks trading at low absolute levels. ${ }^{199}$

In addition, I employ a number of controls that may be related to investor preferences: (1) firm age (AGE), defined as the number of months the firm has appeared in the CRSP database as of March 31, 2010, because institutions may prefer to invest in older, more established firms; (2) stock volatility (STKVOL), defined as the standard deviation of monthly stock returns over the one-year period prior to

198 Brad M. Barber \& Terrance Odean, All That Glitters: The Effect of Attention and News on the Buying Behavior of Individual and Institutional Investors, 21 REV. Fin. STUD. 785, 788 (2008).

199 See Gustavo Grullon, George Kanatas \& James P. Weston, Advertising, Breadth of Ownership, and Liquidity, 17 REv. Fin. STUD. 439, 449 (2004); Ravi Dhar et al., The Impact of Clientele Changes: Evidence from Stock Splits (Mar. 2004) (unpublished manuscript), available at http://papers.ssrn.com/sol3/papers.cfm?abstract_id=410104, archived at http://perma.cc/JUH6-26VV. 
March 31, 2010, because there is evidence that institutional ownership is associated with higher stock volatility for dividend-paying stocks and with lower volatility for nondividend payers; ${ }^{200}$ (3) return on equity (RETONEQ), ${ }^{201}$ because profitable firms are better able to attract investment from institutional investors and there is evidence that firms with higher levels of institutional ownership have higher return on equity ratios; ${ }^{202}$ (4) dividends-to-equity $(D I V T O E Q)^{203}$ because evidence shows that certain types of investors, including tax-exempt institutions and individuals with low marginal tax rates, prefer stocks that pay dividends $;{ }^{204}$ (5) a variable related to asset tangibility-the

200 See Amir Rubin \& Daniel R. Smith, Institutional Ownership, Volatility and Dividends, 33 J. BANKING \& FIN. 627, 627 (2009) (discussing the reasons why the relationship between institutional ownership and volatility differs by dividend payment status).

201 RETONEQ equals earnings divided by book equity. "Earnings" is income before extraordinary items plus income statement deferred taxes minus preferred dividends. "Book equity" is stockholders' equity plus balance sheet deferred taxes. All accounting-related calculations are as of the latest twelve months ("LTM") or most recent available quarter, as of the quarter prior to March 31, 2010, because that is the financial data that would have been available to investors as of March 31, 2010. If LTM data are unavailable for a firm, I substitute the most recent fiscal year's data.

202 See, e.g., Dan S. Dhaliwal et al., Institutional Investors, Financial Health, and Equity Valuation, 17 AsIA-PAC. J. AcCT \& Econ. 151, 152 (2010).

203 DIVTOEQ equals dividends divided by book equity. "Dividends" are the dividends per share at the ex date times shares outstanding divided by book equity, see supra note 201.

204 It should be noted that the evidence on dividend clienteles is mixed. See John R. Graham \& Alok Kumar, Do Dividend Clienteles Exist? Evidence on Dividend Preferences of Retail Investors, 61 J. FIN. 1305, 1306 (2006), for a discussion of multiple studies finding the presence of an institutional investor dividend clientele, survey evidence revealing a perception by financial executives of retail investor preferences for dividends and less conclusive direct evidence on retail investor dividend preferences. Graham and Kumar find that, as a group, the retail investors in their study (which used data from a discount brokerage house's retail accounts) appear to prefer non-dividend paying firms, but that within that group of individual investors, low-income and older investors tend to prefer stocks that pay dividends. Id. at 1307. 
ratio of tangible assets to total assets (TANGASSETS) ${ }^{205}$ because there is evidence that institutional ownership is negatively associated with leverage ${ }^{206}$ and that firms with more tangible assets have greater access to external finance; ${ }^{207}$ and (6) two variables to proxy for characteristics indicating high growth opportunities-most recent annual sales growth $(S A L E S G)^{208}$ and the ratio of book value to market value (BKTOMKT) ${ }^{209}$-because there is evidence that firms with high growth potential may be more attractive to institutional investors. ${ }^{210}$ The book-to-market ratio also proxies for firm undervaluation, which can affect not only institutional investment preferences, but also a firm's

205 TANGASSETS equals property, plant and equipment (Compustat Item 7) divided by total assets (Compustat Item 6).

206 Roni Michaely \& Christopher Vincent, Do Institutional Investors Influence Capital Structure Decisions? 4-5 (Jan. 2013) (unpublished manuscript), available at http://home.business.utah.edu/finmh/ Institutional.pdf, archived at http://perma.cc/2S68-MEX9 (describing the reasons for the relationship between institutional ownership and debt).

207 This is because the availability of hard assets increases the amount that can be captured by creditors in case of default. Heitor Almeida \& Murillo Campello, Financial Constraints, Asset Tangibility, and Corporate Investment, 20 REV. FIN. STUD. 1429, 1430 (2007).

208 SALESG is the change in net sales from 2008 to 2009 divided by 2008 net sales.

209 BKTOMKT equals book equity, see supra note 201, divided by market equity (Compustat stock price * Compustat shares outstanding). A lower book-to-market ratio, which compares book value (accounting value of net assets) to equity market value, implies higher growth opportunities.

210 Professors Dan Dhaliwal, Oliver Zhen Li, and Hong Xie find that higher levels of institutional ownership are associated with lower book-tomarket ratios. Dhaliwal et al., supra note 202, at 167 . These results are at odds with those of Professors Paul Gompers and Andrew Metrick who find that institutional ownership is positively associated with book-to-market ratio. Dhaliwal et al., supra note 202, at 167 n.5 (citing Paul A. Gompers \& Andrew Metrick, Institutional Investors and Equity Prices, 116 Q. J. EcoN. 229, 244 (2001)). In the present study, in some specifications, consistent with Professors Gompers and Metrick, I find the relationship between level of institutional ownership and book-to-market ratio to be positive, which suggests that firms with high growth opportunities may garner more attention in the financial press and on investment blogs and thereby attract more retail, rather than institutional, investor interest. 
vulnerability to hostile takeover. ${ }^{211}$ The latter has implications for institutional tolerance of antitakeover mechanisms.

Finally, I control for membership in the S\&P 500 (SP500). Many mutual funds pursue index fund strategies. Because of data limitations, I am unable to disentangle the activelymanaged portions of a mutual fund's holdings from the indexed portion. Therefore, I control for membership in the S\&P 500 as of March 31, 2010, to avoid spurious correlations. (See Table 1 for summary data and Table 2 for pairwise correlation coefficients for the variables used in this study.)

Following Professors Malcolm Baker and Jeffrey Wurgler, ${ }^{212}$ I winsorize the institutional ownership variable and all the control variables that are not dummy variables at their $0.5 \%$ and $99.5 \%$ values as a check against outliers and influential data points. Regression diagnostics reveal problems with a number of my variables. To correct for deficiencies, I express the size, trading volume, research coverage, research activity, news coverage, age, volatility, asset tangibility, and stock price variables in natural logarithms. I also perform principal component analysis to address multicollinearity problems and subsequently generate one new variable (SIZEVOLRES) for use in my regression analyses that combines SIZE (market capitalization), VOL (trading volume), RESCOV (research coverage) and RESACT (research activity) into one variable.

I compare institutional ownership levels with seven different governance metrics. My first regression specification takes the form:

INSTOWN $=\alpha+\beta I N D E X C G Q_{i}+{ }_{1} D_{D E I N C}+{ }_{2} I R R R E S T_{i}$ ${ }_{+}{ }_{3} S I Z E V O L R E S_{i}+{ }_{4} D_{4} D I V E R S E_{i}+\mathrm{Y}_{5} N E W S C O V_{i}+{ }_{\gamma_{6}} A G E_{i}+$ $\mathrm{Y}_{7} S T K V O L_{i}+\mathrm{Y}_{8} R E T O N E Q_{i}+{ }_{\mathrm{Y}_{9}} D I V T O E Q_{i}+$

211 See 13D Monitor, supra note 211 (discussing how undervaluation may make a firm vulnerable to hostile takeover).

212 Malcolm Baker \& Jeffrey Wurgler, Investor Sentiment and the Cross-Section of Stock Returns, 61 J. Fin. 1645, 1655 (2006). 


$$
\begin{gathered}
\mathrm{Y}_{10} T A N G A S S E T S_{i}+\mathrm{Y}_{11} S T K P R C_{i}+\mathrm{Y}_{12} S A L E S G_{i}+ \\
\mathrm{Y}_{13} B K T O M K T_{i}+\mathrm{Y}_{14} S P 500_{i}+\varepsilon_{i}
\end{gathered}
$$

where INSTOWN is the variable representing the proportion of a firm's stock held by institutional investors; INDEXCGQ is the ISS Index CGQ; DEINC is a dummy variable that takes the value of 1 for firms incorporated in Delaware and 0 otherwise; IRRREST is a dummy variable that takes the value of 1 for firms with a past accounting restatement due to irregularities and 0 otherwise; SIZEVOLRES is a combination of market capitalization, trading volume, research coverage, and research activity; DIVERSE is a dummy variable that takes the value of 1 for firms that operate in more than two industries and 0 otherwise; $N E W S C O V$ is the number of days of news coverage during the study period; $A G E$ is firm age; $S T K V O L$ represents stock volatility; RETONEQ is return on equity; DIVTOEQ is dividends-to-equity; TANGASSETS is the ratio of tangible assets to total assets; STKPRC is stock price; SALESG is sales growth; BKTOMKT is book-to-market ratio; and SP500 is a dummy variable with a value of 1 if a firm is a member of the S\&P 500 and 0 otherwise.

In model specification (2), INDUSCGQ, the ISS Industry CGQ, replaces INDEXCGQ. In model specification (3), ISSINTERNAL, the components of ISS' Index CGQ that relate to internal governance, replaces INDEXCGQ. In model specification (4), EINDEX, the Bebchuk, Cohen, and Ferrell E-Index score, replaces INDEXCGQ. In model specification (5), GINDEX, ${ }^{213}$ the Gompers, Ishii and Metrick G-Index score, replaces INDEXCGQ. In model specification (6), ISSEXTERNAL, the components of ISS' Index CGQ that relate primarily to external governance, replaces INDEXCGQ. In model specification (7), ANNDIRELEC, which represents the absence of a staggered board, replaces INDEXCGQ.

Table 3 reports the results of these regressions, including heteroskedasticity-robust t-statistics, and robust standard

213 G-Index scores are not available after 2007, so the G-Index regression is as of March 31, 2007. 
errors, and shows that governance metrics that are exclusively or largely internally focused (INDEXCGQ, INDUSCGQ, and ISSINTERNAL) are positively associated with institutional ownership. The results are statistically significant (p-value < 0.01, 0.01, and 0.1 for INDEXCGQ, INDUSGGQ, and ISSINTERNAL, respectively) and economically significant. ${ }^{214}$ A one standard deviation increase in INDEXCGQ, INDUSCGQ, and ISSINTERNAL is associated with a $1.6 \%, 2.2 \%$, and $1.0 \%$ increase in institutional ownership, respectively. An increase in the quality of governance as measured by INDEXCGQ from the $25^{\text {th }}$ percentile to the $75^{\text {th }}$ percentile is associated with an increase in institutional ownership of $4.0 \% .^{215} \mathrm{~A}$ similar governance quality increase with respect to INDUSCGQ and ISSINTERNAL is associated with a $5.9 \%$ and $4.0 \%$ increase in institutional ownership, respectively.

I also find that ANNDIRELEC (annual director elections) is associated with higher levels of institutional ownership ( $\mathrm{p}$ value $<0.1$ ). I find no statistically significant relationship between three measures of external governance-EINDEX,

214 Given the trillions of dollars under management by institutional investors, even seemingly small percentage changes in institutional ownership can represent sizable sums. In addition, evidence on reverse stock splits may prove useful in this context. Firms often do reverse stock splits to raise a company's absolute stock price in order to attract institutional investors. According to one study, in the two-year period before the initiation of a reverse stock split, institutional investment declined, on average, by $1.3 \%$. Kee H. Chung \& Sean Yang, Reverse Stock Splits, Institutional Holdings, and Share Value 41 tbl.I (Oct. 1, 2014) (unpublished manuscript), available at http://papers.ssrn.com/sol3/ papers.cfm?abstract_id=1785774, archived at http://perma.cc/XR22-TWFQ. If a $1.3 \%$ decline can induce, at least in part, firms to undergo a reverse stock split in hopes of attracting institutional investment dollars, then it is fair to say that a $1.0 \%-5.9 \%$ difference in institutional investment is economically significant.

215 Consistent with Professors Kee Chung and Hao Zhang, I calculate this as follows: (OLS Estimated Regression Coefficient on Index CGQ (see Table 3, column 1) * (75th percentile value of Index CGQ - 25th percentile value of Index CGQ))/Mean Overall Institutional Ownership of Sample Firms in Regression Equation. See Chung \& Zhang, supra note 16, at 255 n.11. 
GINDEX, and ISSEXTERNAL-and INSTOWN (institutional ownership). However, this finding (and other such findings as described below) does not mean no relationship exists, only that my data do not allow me to draw any empirically sound conclusions about the nature of the relationship among these variables.

To assess whether the relationship between institutional ownership and governance quality varies by institution type, I perform the regression analyses described above and replace the dependent variable institutional ownership with the following: bank ownership; insurance company ownership; investment company (mutual fund) ownership; corporate (private) pension fund ownership; public pension fund ownership; university and foundation endowment ownership; and other institutional ownership (which includes hedge funds). Table 4 reports the results of these regressions, including heteroskedasticity-robust t-statistics and robust standard errors, and shows that higher quality governance as measured by INDEXCGQ is positively associated not only with INSTOWN (overall institutional ownership) (p-value < 0.01), but also with level of mutual fund ownership ( $\mathrm{p}$-value $<0.01$ ) and bank ownership ( $\mathrm{p}$-value $<$ 0.05). However, there is no statistically significant relationship between INDEXCGQ and any other type of institutional ownership.

Higher quality governance measured by INDUSCGQ is positively associated not only with overall institutional ownership ( $p$-value < 0.01), but also with level of bank ownership ( $p$-value $<0.05)$, mutual fund ownership ( $p$-value $<0.01$ ), and public pension fund ownership ( $p$-value $<0.1$ ). This suggests that banks, mutual funds, and public pension funds prefer firms with high-quality, internally focused corporate governance relative to their industry peers. I find no statistically significant relationship between INDUSCGQ and insurance company ownership, corporate pension fund ownership, university and foundation endowment ownership, or ownership by other types of institutional investors. Highquality governance as measured by ISSINTERNAL is positively associated with overall institutional ownership (p- 
value $<0.1$ ) and bank ownership (p-value $<0.1)$. I find no statistically significant relationship between ISSINTERNAL and any other type of institutional ownership. Combined, these results suggest that the preference for internal governance mechanisms is shared broadly across institution types.

The results of the regression analysis for the measures of external governance differ significantly from those related to internal governance. Higher levels of ownership by insurance companies ( $p$-value $<0.05$ ) and public pension funds ( $p$-value $<0.01)$ are associated with lower quality external governance (i.e., lower vulnerability to the market for corporate control), as measured by GINDEX. (Recall that the lower the EINDEX and GINDEX, the better the external corporate governance is assumed to be.) I find no statistically significant relationship between GINDEX and INSTOWN (overall institutional ownership), bank ownership, mutual fund ownership, corporate pension fund ownership, university and foundation endowment ownership, or other institutional ownership. I also find a positive relationship (pvalue $<0.05)$ between bank ownership and EINDEX, again, a sign of poor quality external governance. Otherwise, I find no statistically significant relationship between EINDEX or ISSEXTERNAL and institutional ownership of any other type. Taken together, these results seem to suggest that, to the extent there is an institutional preference, it is for internal governance mechanisms over external governance mechanisms.

However, I find one area in which there appears to be an overall institutional preference for high-quality external corporate governance: annual director elections. Both overall institutional ownership ( $\mathrm{p}$-value $<0.1$ ) and mutual fund ownership ( $p$-value < 0.05) are associated with higher quality external governance as measured by the absence of a staggered board. No statistically significant relationship exists between ownership by banks, insurance companies, private pension funds, public pension funds, university and foundation endowments, or other institutions and the absence of a staggered board. This suggests that the 
association between overall institutional ownership and the seeming preference for non-staggered boards (ANNDIRELEC) described previously is largely driven by mutual funds. This is not surprising because mutual fund ownership is, on average, approximately $45 \%$ of the total ownership of the firms in my sample and dwarfs the percentage ownership of other types of institutional investors.

The preceding analysis treats internal governance and external governance as separate categories of corporate governance. However, it is possible that internal governance and external governance are related in such a way that merits a joint review of the two types of governance devices. Internal and external governance may be substitutes for one another (i.e., low-quality governance of one type can be made up for by high-quality governance of another type). A study performed by Professors Stuart Gillan, Jay Hartzell, and Laura Starks provides an example of governance substitution by showing that firms that are less vulnerable to takeovers have higher levels of board independence. ${ }^{216}$

Internal governance and external governance also can function as complements. Professors Martijn Cremers and Vinay Nair find that high-quality external governance is associated with a statistically significant annualized abnormal return of $10-15 \%$ only when coupled with a large blockholder or high levels of public pension fund ownership, which the researchers consider indicia of high-quality internal governance. ${ }^{217}$ They suggest that this complementarity can lead to higher value in at least one scenario: the presence of a large shareholder can be crucial to facilitating a successful takeover attempt. This suggests that firms that lack a large monitoring shareholder may not be taken over, even if they have no antitakeover devices in effect. $^{218}$

216 Stuart L. Gillan, Jay C. Hartzell \& Laura T. Starks, Tradeoffs in Corporate Governance: Evidence from Board Structures and Charter Provisions, 1 Q. J. FIN. 667, 668 (2011).

217 Cremers \& Nair, supra note 13, at 2862.

218 Id. at 2860. 
To test whether internal corporate governance quality interacts with external governance quality to predict level of institutional ownership, I perform a regression analysis using INDEXCGQ; transformed EINDEX variable, REVEINDEX $;^{219}$ and INDEXCGQ*REVEINDEX as the independent variables of interest. Prior to creating a variable to represent the interaction of INDEXCGQ and REVEINDEX, I center ${ }^{220}$ the variables INDEXCGQ and REVEINDEX by subtracting the sample mean from each variable's value. In untabulated results, I find that there is a positive and statistically significant relationship $(\mathrm{p}<0.05)$ between INSTOWN (institutional ownership) and INDEXCGQ (high-quality (primarily) internal governance), but no statistically significant relationship between INSTOWN (institutional ownership) and high-quality external governance (REVEINDEX) or between the interaction term INDEXCGQ*REVEINDEX and INSTOWN (institutional ownership). These results suggest that, from the perspective of institutional investors, internal and external corporate governance are not substitutes (e.g., poor internal governance is fine only if there is strong external governance) and that the efficacy or attractiveness of internal governance is not dependent on external governance or vice-versa.

219 Because of the necessity of generating an interaction term for INDEXCGQ and EINDEX, I transformed EINDEX to REVEINDEX by subtracting the value of EINDEX from the number six. Six is the highest possible EINDEX score, and higher EINDEX scores denote poor external governance. Because high INDEXCGQ scores indicate good internal governance, I transformed EINDEX to REVEINDEX so that a higher, rather than a lower, external governance score also would represent good governance.

220 Rebecca M. Warner, Applied Statistics: From Bivariate Through Multivariate Techniques 632 (2d. ed. 2013) ("The purpose of centering is to reduce the correlation between the product [interaction] term and the $\mathrm{X}_{1}, \mathrm{X}_{2}$ scores, so that the effects of the $\mathrm{X}_{1}$ and $\mathrm{X}_{2}$ predictors are distinguishable from the interaction."). 


\section{Pooled OLS Regression Analysis}

As an additional tool to assess the relationship between corporate governance and institutional ownership, I perform pooled OLS regression analysis using the period 2002-2010. The 2010 OLS regression analysis affords me an opportunity to assess whether firms with high-quality corporate governance have higher levels of institutional ownership as of a fairly recent single point in time (i.e., March 31, 2010). Employing pooled OLS regression analysis, which uses multiple observations from the same firm over time, provides an added benefit over the 2010 OLS crosssectional regression analysis because it examines the relationship between institutional ownership and corporate governance quality over a multi-year period.

I use annual corporate governance data from 2002, the year of the launch of the ISS CGQ, to 2010, the year in which ISS discontinued publication of CGQ's. ${ }^{221}$ The dependent variable is institutional ownership. I compare institutional ownership levels with seven different governance metricsINDEXCGQ, INDUSCGQ, ISSINTERNAL, ${ }^{222}$ EINDEX, GINDEX (through the last year of available data, 2007), ISSEXTERNAL, 223 and ANNDIRELEC (no staggered board). In the pooled OLS regressions, I employ the same control

221 The precise dates of the data used in the analysis are September 30, 2002, the first date on which CGQ data were published (outside of publication in a pilot program on December 31, 2001); March 31, 2003; March 31, 2004; March 31, 2005; March 31, 2006; March 31, 2007; March 31, 2008; March 31, 2009; and March 31, 2010.

222 ISSINTERNAL and ISSEXTERNAL are generated by summing the number of internal or external governance best practices, respectively, employed by a firm. The CGQ factors changed slightly in 2006 and then again in 2007. Thus, to have comparable metrics over the 2002-2010 study period, I converted ISSINTERNAL and ISSEXTERNAL to percentage scores (ISSINTERNALPERC and ISSEXTERNALPERC) that reflect the percentage of ISS-defined best practices employed by each firm in my sample. Using ISSINTERNALPERC and ISSEXTERNALPERC in place of ISSINTERNAL and ISSEXTERNAL does not change my results qualitatively.

223 See supra note 222. 
variables, as of the relevant time period, as were used in the 2010 OLS regression analysis. ${ }^{224}$

In my analysis, I cluster at the firm level. Within a single regression, assuming no missing data, each firm yields nine observations (one for each data point in the years 20022010), which leads to clustered errors due to correlation among observations within each firm. Failure to cluster at the firm level can lead to incorrect standard errors and incorrect inferences about the strength of the relationship between corporate governance and institutional ownership. I also employ year fixed effects (i.e., I control for factors occurring in any time period-for example, overall public pension fund investment in 2007) that could affect institutional ownership.

Table 5 reports the results of these pooled OLS regressions with robust standard errors clustered at the firm level. Consistent with the 2010 OLS analysis, there is a positive relationship between INSTOWN (overall

224 All accounting-related calculations are as of the latest twelve months ("LTM") or the most recent available quarter, as of the quarter prior to March 31 of the relevant year, or in the case of 2002, prior to September 30. If LTM data are unavailable for a firm, I substitute the most recent fiscal year's data. Irregularity restatement history is limited to restatements that occurred post-SOX. I focus on restatements post-SOX because these restatements may be, in part, a reflection of the internal control requirements imposed by Sarbanes-Oxley. Prentice \& Spence, supra note 79, at 1871. Given the perceived permissiveness of auditing firms pre-SOX, Professors Prentice and Spence argue that a pre-SOX restatement is "a sign that management had been busted by its auditor for stretching numbers beyond all bounds of plausibility." Id. Post-SOX, with the heightened focus on financial control, restatements could be perceived as an example of a company "trying to get [its financial reporting] right." Id. Rep. Paul Sarbanes agrees that "[w]hereas before the passage of the legislation the escalating number of restatements was a danger sign, the numbers today indicate that the internal control requirements are having the desired effect." Paul Sarbanes, Living Up to Its Promise SarbanesOxley Pays Dividends by Keeping Companies Honest, RockY MoUnTAIN News (Denver), Apr. 8, 2006, at 2C, cited in Prentice \& Spence, supra note 79 , at 1871 n.136. Investors seem to make this pre- and post-SOX distinction, as firm stock prices declined on average $10 \%$ following a preSOX restatement, but only $2 \%$ following a post-SOX restatement. Prentice \& Spence, supra note 79 , at 1871 n.136. 
institutional ownership) and high-quality internal corporate governance, as measured by INDEXCGQ (p-value < 0.05), INDUSCGQ (p-value < 0.01), and ISSINTERNAL (p-value < 0.01). The analysis also reveals a statistically significant positive relationship ( $\mathrm{p}$-value $<0.1$ ) between INSTOWN (overall institutional ownership) and GINDEX. This suggests an overall institutional preference for low-quality external governance as measured by the G-Index. I find no statistically significant relationship between any other external governance quality measure and overall institutional ownership.

Table 6 reports the results of pooled OLS regressions that explore the relationships between corporate governance metrics and institutional ownership by type of institution. My analysis reveals that in addition to INSTOWN (overall institutional ownership) (p-value $<0.01$ ), mutual fund ( $p$ value $<0.05$ ), bank ( $p$-value $<0.05$ ), and insurance company (p-value < 0.01) ownership are positively associated with INDEXCGQ. Similarly, mutual fund ( $\mathrm{p}$-value $<0.01$ ), bank ( $p$-value $<0.01$ ), insurance company ( $p$-value $<0.01$ ), public pension fund ( $p$-value $<0.01)$, and other institutional ownership ( $p$-value $<0.1)$ have a statistically significant positive relationship with INDUSCGQ. These results, combined with the positive relationship I find between ISSINTERNAL and mutual fund ( $\mathrm{p}$-value < 0.1), bank ( $\mathrm{p}$ value $<0.01$ ), insurance company ( $\mathrm{p}$-value $<0.01$ ), public pension fund ( $p$-value $<0.01$ ), and corporate pension fund ownership ( $p$-value $<0.1$ ), suggest a preference by almost all institutional investor types for purportedly high-quality internal governance.

I also find a positive relationship ( $p$-value $<0.1)$ between mutual fund ownership and ANNDIRELEC (annual director elections). This suggests that mutual fund managers are attracted to firms that do not have staggered boards. This stands in stark contrast to the negative relationship (p-value $<0.01$ ) I find between public pension fund ownership and ANNDIRELEC. Ownership by public pension funds is associated not only with low-quality external governance in the form of a staggered board, but also, in the form of higher 
EINDEX (p-value < 0.01), higher GINDEX (p-value < 0.01), and lower ISSEXTERNAL (p-value < 0.01). The pooled OLS analysis suggests a preference on the part of public pension funds for high-quality internal governance and weak external governance. Ownership by insurance companies and banks is also associated with low-quality external governance, as both types of institutional ownership have negative relationships with ISSEXTERNAL (p-value $<0.05$ and $<0.01$, respectively) and positive relationships with EINDEX (p-value $<0.1$ and $<0.05$, respectively) and GINDEX (p-value $<0.01$ and $<0.05$, respectively).

In this study, I have explored the question of institutional preferences in corporate governance. Though mixed, the weight of the evidence suggests, overall, that institutions prefer high-quality internal governance over high-quality external governance.

\section{Causation}

The foregoing analysis provides a useful framework for understanding the relationship between particular governance practices and institutional ownership. Even though the results demonstrate that particular governance metrics are associated with institutional ownership, given the econometric technique I use (OLS regression), I can make no causal claims. However, the evidence presented is strongly suggestive of the fact that either institutions are attracted to firms with certain governance characteristics or the presence of institutional investors leads firms to adopt such mechanisms - or both. ${ }^{225}$ Either way, assuming I have controlled for potentially confounding factors, finding associations between particular governance metrics and higher levels of institutional ownership suggests these metrics generally measure governance characteristics that are consistent with institutional preferences.

225 Evidence suggests both can be true. See, e.g., Bushee, Carter \& Gerakos, supra note 17, at 4-5 (discussing evidence on institutional preferences for pre-existing governance characteristics and shareholder activism). 


\section{ALTERNATIVE EXPLANATIONS FOR FINDINGS AND POLICY IMPLICATIONS}

\section{A. Review of Alternatives}

The results of this study suggest that, like Congress, institutional investors are largely unconcerned with investing in companies with governance mechanisms "proven" to enhance firm performance. There are a number of potential conclusions one could draw about these seeming preferences.

\section{Misinformed or Irrational Investors}

This study could demonstrate that institutional investors are just as misinformed and inept as members of Congress are alleged to be: institutions have a preference for internal governance mechanisms because they are holding on to governance-related "myths" and "superstitions" that bear no relationship to reality. ${ }^{226}$ This is certainly possible, but it seems unlikely. It is standard procedure in the finance and corporate law literatures to study stock market reactions to changes in laws or policies-that is, to engage in event studies. ${ }^{27}$ Researchers do this because of the prevailing view that stock price movements following legal changes tell us something useful about the efficacy of a new law or policy. During the time of this study, institutional trading in NYSE

226 See supra Part II.B (describing the views of Professor Jeffrey Sonnenfeld who argues that the factors considered in generating corporate governance ratings are largely the product of "Wall Street superstitions" and "clichés and myths, rather than ... genuine research").

227 See generally Thomas Stratmann \& J.W. Verret, Does Shareholder Proxy Access Damage Share Value in Small Publicly Traded Companies?, 64 STAN. L. REV. 1431, 1445 (2012) ("The three-part mandate of promoting efficiency, competition, and capital formation, combined with the D.C. Circuit's willingness to overturn SEC rules that lack sufficient empirical foundation, has undoubtedly contributed to the popularity of SEC rules as targets of empirical study. Stock price event studies have been the most popular method for commentators considering the effect of events that alter the probability that proxy access legislation or rules would be implemented."). 
stocks represented $98-99 \%$ of all trades, so the views of institutions, not retail traders, are clearly those being sought by researchers. If researchers routinely attribute significant meaning to investors' short-term (sometimes as little as oneday) stock price reactions, which represent short-term buying and selling following a significant announcement, it seems reasonable to attribute meaning to institutions' governance preferences as revealed in the present study.

Relatedly, this study's results could demonstrate that institutions are not generally irrational actors, but were acting irrationally during the study period in reaction to fear caused by large-scale market scandals. That explanation, too, seems unlikely. In unreported results for an OLS regression analysis using data as of March 31, 2005 only, I generally find the same relationships as those described in this paper. The year 2005 is three years after the Enron scandal and three years prior to the financial crisis. Thus, this is a time period far removed (in Wall Street terms) from the scandals that could lead to fear-induced preferences.

\section{Agendas Unrelated to Wealth Maximization}

The preference for governance mechanisms with mixed empirical support could mean that institutional investors have an agenda unrelated to maximization of shareholder welfare. Such charges have been leveled, for example, against public pension funds. Professor Bainbridge, for example, attributes the passage of what he views as the misguided mandate for $100 \%$ compensation committee independence to union and public pension fund advocacy. ${ }^{228}$ There is no doubt that institutional investors are not a monolithic group and have varying preferences. However, the findings in this study, to the extent I find a statistically significant relationship, are generally consistent across all institutional types. My pooled OLS analysis shows that not only public pension funds, but, in general, all institutional investors prefer purportedly high-quality internal governance, despite the fact that the evidence with respect to 
efficacy is mixed at best. There is no reason to believe that all institutional investors, including mutual funds, banks, and insurance companies, are motivated by political considerations over return maximization. As I more fully discuss in Part IV.B.1, infra, shareholders may make the decision to invest in firms with high-quality internal governance because they believe in the common sense intuition that independence from management is helpful in circumstances such as setting CEO compensation and auditing financial statements prepared by management. It may turn out that these investors are wrong, but there is no evidence to suggest that they are making this choice because they are indifferent to firm profitability.

Also, there is no evidence that public pension funds are more likely than other investor types to advocate for corporate policies that that they believe would depress returns and be adverse to the financial interests of their beneficiaries. Indeed, the available evidence shows that pension funds consistently outperform mutual funds, and this is after accounting for the different cost structures of the two types of institutions. ${ }^{229}$

\section{Blind Herding}

The relationship between institutional ownership, on the one hand, and high-quality internal governance and poorquality external governance, on the other hand, simply could be a reflection of the fact that institutions are lemmings that blindly follow ISS because investment managers are too lazy (or feel ill-equipped) to make their own assessments about

229 After comparing the returns of 716 defined benefit pension plans and 4,030 mutual funds over the 1992-2004 time period, Professors Rob Bauer and Rik Frehen find that the "pension funds outperform mutual funds by approximately 250 basis points per year. After size-matching the mutual fund sample, differences are reduced to roughly 150 basis points. Costs are only to a minor extent responsible for the net performance differential. Risk and style corrections widen the performance gap to more than 200 basis points." Rob Bauer \& Rik Frehen, The Performance of US PENsion Funds 2-3 (2008), available at http://arno.uvt.nl/ show.cgi?fid=78520, archived at http://perma.cc/2RDK-CL69. 
governance quality. However, there is evidence against ISSinduced blind herding generally. After examining the relationship between shareholder votes and voting recommendations from proxy advisors ISS, Glass Lewis, Proxy Governance, and Egan Jones, Professors Steve Choi, Jill Fisch, and Marcel Kahan find that institutional investors do not blindly follow voting recommendations of proxy advisors. ${ }^{230}$ Instead, they find that recommendations from ISS, the most powerful proxy advisory firm, shift investor votes by no more than $6-10 \% .^{231}$ This is a material percentage, but still indicative of less power than traditionally ascribed to ISS. ${ }^{232}$ Importantly, Professors Choi, Fisch and Kahan find that ISS, more than other competing proxy advisors, bases its recommendations on the considerations deemed most important by their institutional investor clients. Thus, the researchers conclude, "ISS is not so much a Pied Piper followed blindly by institutional investors as it is an information agent and guide, helping investors to identify voting decisions that are consistent with their existing preferences." ${ }^{233}$ Just as Professors Choi, Fisch and Kahan argue with respect to proxy voting, I submit that perhaps ISS' governance rating methodology to a large extent merely reflects the pre-existing preferences of institutional investors.

My study demonstrates that there is a statistically significant relationship between mutual fund and public pension fund ownership, on the one hand, and the ISS Index CGQ and/or ISS Industry CGQ, on the other hand. Mutual fund and pension fund managers, as described below in Part IV.A.4, have reason to follow ISS' recommendations. That said, there is still reason to doubt a blind herding explanation for this study's findings. According to a 2007 report, Ashton Partners, a strategic advisory firm that

230 Stephen Choi et al., The Power of Proxy Advisors: Myth or Reality?, 59 Emory L.J. 869, 905-06 (2010).

231 Id

232 Id. Press reports claim that ISS recommendations can shift as much as $20-30 \%$ of shareholder votes. $I d$. at 905 .

233 Id. at 906. 
specializes in communications and investor relations, surveyed 200 portfolio managers and buy-side analysts. ${ }^{234}$ Approximately one-third of those surveyed had never even heard of the ISS CGQ. ${ }^{235}$ Another third claimed to be aware of the $\mathrm{CGQ}^{236}$ of the firms in which they were considering investments, but said the corporate governance rating was not a factor in their investment decisions. ${ }^{237}$ It is true that several years have elapsed since this survey was taken. ISS' profile certainly has risen since. However, in unreported results, I find that the positive relationship between institutional ownership and ISS corporate governance scores persists each year throughout the 2002-2010 period, which includes time periods before this survey was administered. This evidence, though admittedly limited, casts doubt on the presence of blind herding.

In addition, ISS takes a decidedly negative view of antitakeover mechanisms, yet the evidence in this study is clear: higher numbers of antitakeover devices are associated with higher levels of institutional ownership in many cases. This, too, is inconsistent with blind herding.

\section{Criticism Insurance}

Another possible explanation for my finding of a positive relationship between institutional ownership and internal corporate governance lies in institutional investors' use of ISS ratings as "criticism insurance." Professor Rose suggests that ISS' large amount of influence is related to the fact that pension funds and mutual funds, pursuant to federal law,

234 Foley \& LaRdner LLP, Research Analyst Views of CoRPorate GOVERNANCE 1 (2007), available at http://www.foley.com/files/ Publication/d86cd0ab-94ce-4a43-9881-f0beacb1bd9a/Presentation/ PublicationAttachment/59dd7bff-8711-4765-9f50-f0fff2fe73ef/Research AnalystViewsofCorpGov.pdf, archived at http://perma.cc/WC9N-F8NF.

235 Id.

236 The actual language in the Foley \& Lardner release uses the generic term "corporate governance," but from the context, it seems reasonable to conclude that the references are to the CGQ and not to corporate governance more broadly. See id.

237 Id. 
must vote proxies in the best interests of their investors or beneficiaries. ${ }^{238}$ As fiduciaries, pension plan and mutual fund managers must conduct due diligence in connection with their proxy voting. ${ }^{239}$ Following the voting recommendation of ISS may provide "criticism insurance," as a fund manager voting consistent with an ISS recommendation has "no burden of proof with respect to a particular proxy vote" and is unlikely to be found to have violated her fiduciary duties after following the expert advice of a proxy advisory firm. ${ }^{240}$ One could argue that this also could be the case with corporate governance ratings.

If this is the case, even if ISS' governance metric is wrong about the quality of a particular firm's governance practices and investing in such firm leads to investment losses from, say, fraud, at least an investment manager can take cover by pointing out that she was one of many institutions with an investment in the fraudster. Therefore, an investment manager may perceive the safest course to be one in which she invests in firms that have received the ISS governance "stamp of approval." In other words, investing in ISSsanctioned companies provides a type of "criticism insurance." 241

This potential explanation, too, seems unlikely. In this study, I assess the relationship between institutional ownership and a significant type of governance breakdowna firm's history of accounting restatements due to "irregularities" (i.e., misconduct) and find, in the 2002-2010 pooled OLS analysis, that higher proportions of institutional ownership are associated with a higher likelihood of prior restatements due to irregularities. If institutions' apparent preference for internal corporate governance is driven by fear of fraud, it is puzzling to see a positive relationship between restatements due to misconduct and institutional ownership. This result is inconsistent with the assertion that

238 Rose, supra note 4 , at 916.

239 Id

$240 I d$

241 Id. 
institutional investors are so frightened by the prospect of fraud that they would use the ISS rating as criticism insurance. If investment managers are worried about facing criticism if a portfolio company were to become involved in fraud, they would be less likely to invest in firms with a history of restatements due to irregularities. ${ }^{242}$ Surely, such managers would receive as much, if not more, criticism for investing in a company with a known history of wrongdoing than for investing in a firm with a comparatively low CGQ score.

\section{Omitted Variable Bias}

The relationship I find between governance mechanisms and institutional ownership could be a product of omitted variable bias-i.e., my model is missing a factor or factors related to the choice of governance mechanisms and institutional ownership. The use of a large number of control variables informed by finance theory in my analyses goes a long way toward addressing this concern. However, the possibility cannot be ruled out completely.

242 Of course, this finding does not necessarily mean that institutions actively seek out fraudsters. There are at least two possible alternative explanations for this result. First, following restatements due to irregularities, either the CEO or CFO typically (in about $90 \%$ of the cases, according to one study) is removed from office in the short-term. See Hennes, Leone \& Miller, supra note 193, at 1490. Thus, a history of accounting irregularities does not mean that a firm's corporate governance going forward necessarily will be poor. Indeed, governance could conceivably improve following a management shake-up and the governance reforms likely to follow shareholder litigation or regulatory scrutiny, which would make such firms more attractive to institutions. Second, it is possible that the presence of a large institutional shareholder base makes firm managers more likely to engage in financial misreporting. See supra Part III.C.1, for further discussion of this final point. 


\section{B. Policy Implications}

\section{Internal Governance}

Because I largely find all of the foregoing alternative explanations wanting, I am left with the conclusion that institutional investors prefer internal governance mechanisms because they believe, even in the absence of empirical support, that such mechanisms are value enhancing. This conclusion is consistent with the history of institutional influence on governance in the U.S.

As Professor Jeff Gordon notes, from the mid-1980s to the mid-2000s, the percentage of independent directors on corporate boards increased substantially, ${ }^{243}$ not due to management-initiative, but in response to shareholder demand. ${ }^{24}$ Thus, Professor Gordon suggests that the move from advisory boards to monitoring boards was driven not by regulatory intervention, but rather by market forces. ${ }^{245}$ Though it is true, as Professor Macey suggests, that the law in Delaware has encouraged the use of independent directors in situations such as evaluating hostile bids and responding to derivative suits, no Delaware judicial decisions have required that a majority of a board be independent or that a board perform only monitoring functions. ${ }^{246}$ Of course, Sarbanes-Oxley and stock exchange rules now require board independence, but these mandates are of fairly recent origin and largely reflect prevailing corporate norms. ${ }^{247}$ The most significant cause of the move to independent monitoring boards has been the market pressure imposed by institutional investors. ${ }^{248}$

243 See Gordon, supra note 94, at 1474 fig.1, 1476. Although measuring a different time period, it is interesting to note that, in 1950, independent directors made up about $20 \%$ of the membership of a board. In 2005 , that percentage stood at $75 \%$. Id. at 1475 .

244 Klausner, supra note 119, at 1358.

245 Fisch, supra note 31 , at 930.

246 Id.

247 Id.

248 Id. 
Prior to the SOX mandate, $70 \%$ of public company audit committees were composed entirely of independent directors, ${ }^{249}$ and prior to the Dodd-Frank imposed stock exchange mandate and previous exchange requirements, $77 \%$ of public companies had fully independent compensation committees. ${ }^{250}$ Of course, these outcomes cannot be attributed solely to institutional investor pressure, ${ }^{251}$ but it

249 This figure is based on a sample of 1,269 public companies. The Sarbanes-Oxley audit committee independence requirement did not bring about a drastic change in corporate practice. In 2002, immediately prior to passage of Sarbanes-Oxley, $90 \%$ of a sample of public company audit committee members, on average, were independent, and $70 \%$ of the public companies in this sample had fully independent audit committees. DUGAN ET AL., supra note 73, at 18-19. Note: these percentages are based on ISS Governance Research Service's ("GRS") definition of independence. This standard, with limited exceptions, is more stringent than the NYSE standard for non-affiliation and hence independence. However, there is substantial overlap, as, in 2005, 93\% of directors were characterized identically as either independent or not independent by the NYSE and GRS. Id. at 14-15. Stock exchange rules promulgated in 1999 required listed firms to either have fully independent audit committees or make a special board determination that it was in the best interest of the company to have one member (out of three or more total members) be nonindependent. In $2002,70 \%$ of boards in this sample apparently voluntarily determined it was in the best interest of their firms to have audit committees made up entirely of independent directors. Indeed, a majority of public companies (56\%) had fully independent audit committees in 1999, before the effective date of the new stock exchange rules on audit committee independence. ERNST \& Young, THE SARBANES-OXLEY ACT AT 10: ENHANCING THE RELIABILITY OF FINANCIAL REPORTING AND AUdiT QUALITY 4 fig. (2012), available at http://www.ey.com/Publication/ vwLUAssets/The_Sarbanes-Oxley_Act_at_10_-_Enhancing_the_reliability _of_financial_reporting_and_audit_quality/\$FILE/JJ0003.pdf, archived at http://perma.cc/E2Y5-52WL. Thus, audit committee independence in the absence of a regulatory mandate or encouragement was already common practice.

250 See DUGAN ET AL., supra note 73. This figure is based on a sample of 1,269 public companies. Id.

251 For example, part of the impetus for compensation committee independence is likely found in Internal Revenue Code Section 162(m)(4)(C)(i), passed under the 1993 Tax Act, which prohibits deducting public company employee compensation in excess of $\$ 1,000,000$ unless the excess compensation is earned pursuant to the achievement of performance goals determined by a firm's compensation committee 
also would be unfair to say that the move toward board independence was forced upon companies exclusively by legislative fiat.

The available empirical evidence does suggest that investors prefer internal governance mechanisms. One study finds that investors prefer independence and tend to reward improved corporate governance practices. ${ }^{252}$ For example, the appointment of an outside, independent director is associated with higher follow-on stock prices than the appointment of an inside director. ${ }^{253}$ There is also evidence that the market values both board independence and audit committee independence. ${ }^{254}$ One study finds that investors rewarded firms that voluntarily adopted these measures before they were subject to regulatory mandate with higher stock prices. ${ }^{255}$ Another study finds that the adoption of several SOX provisions, including those related to director independence, resulted in abnormal positive returns for large and mid-sized companies who did not previously have such governance characteristics. ${ }^{256}$

Institutional investors are run by professional managers who are better equipped than legislators or academics to understand what is in their institutions' best interests. As a firm's residual claimants, they arguably bear the costs of poor governance and the implementation of inefficient governance mechanisms more so than any other corporate stakeholder. If institutional investors have decided that high-quality internal governance characteristics are desirable, then that judgment should be afforded significant weight in assessing the efficacy of these mechanisms.

This, therefore, leads to a question: Is it fair to refer to legislative mandates as quackery when the mandates are

composed of two or more outside directors. I.R.C. $§ 162(\mathrm{~m})(4)(\mathrm{C})(\mathrm{i})(2013)$. See Jack S. Levin et al., Code Section 162(m) - \$1 Million Deduction Limit on Executive Compensation, 63 TAX Notes 723, 731 (1994).

252 Prentice \& Spence, supra note 79, at 1867.

253 Id.

254 Id. at 1878.

255 Id.

256 Id. at 1879. 
consistent with then-existing practices of $70-80 \%$ of public companies and with institutional investor preferences? Perhaps it is. Of course, there is no unanimity among institutional investors or companies about preferred governance structures. Just because $70-80 \%$ of firms have a certain mechanism, or institutions express a preference for it, it does not mean that $100 \%$ of firms should be forced to adopt it, even if it is value enhancing for some. There may be valid reasons for why the other $20-30 \%$ have chosen not to do so, and it is possible that forcing adoption could be value destroying. However, there may be no valid reason why the other 20-30\% have chosen not to adopt the mechanism, and employing a particular governance device such as an independent compensation committee or an audit committee might truly be a best practice. It certainly seems prudent to prohibit those whose livelihood or income is determined by a company's executive officers from deciding the compensation of those executives or reviewing the financial reporting decisions of those officers. Indeed, within the universe of mandates Congress could have imposed (and did impose, such as the 404 internal control certification requirement in Sarbanes-Oxley), requiring any inside and affiliated directors to be removed from audit and compensation committees and replaced by independent, outside directors is relatively inexpensive. Though the practice of fully independent audit and compensation committees was not universal prior to the Sarbanes-Oxley, Dodd-Frank, and stock exchange mandates, the practice was sufficiently widespread and consistent with the preferences of institutional investors, the purported protected class, that Congress could have reasonably concluded that blanket mandates in these areas were more cost-effective than allowing firms to make individualized determinations with respect to mechanism efficacy. ${ }^{257}$

In light of these factors, I offer the following. In the corporate governance area, there are a number of contradictory empirical findings with respect to device

257 There is no evidence that this is what Congress did. Here, I merely suggest that it would not be unreasonable for Congress to reach this conclusion. 
efficacy, and this trend shows no signs of abating. Even if Congress had carefully reviewed the empirical evidence before passing the Sarbanes-Oxley and Dodd-Frank governance mandates, what should have been the outcome following that review? Should Congress have declined to act in the absence of clear evidence?

Today, we are relatively far removed from the crises that plagued the nation before the passing of SOX and DoddFrank, but, unfortunately, we still do not have a consensus on what works in internal corporate governance some thirteen years after the passage of SOX and five years after the passage of Dodd-Frank. If the critics' argument is that Congress should not act in the absence of clear empirical evidence, then this necessarily means that regulators will not take action until a consensus on what works in corporate governance emerges. Dispensing with all mandates and leaving it to the market to decide is the goal of some, for sure. However, to the extent one believes that capital markets failure exists and that regulation to rein in managerial overreaching is necessary, then a norm that requires waiting for an academic consensus before acting is deeply unsatisfying. In this Article, I make the modest claim that, if one must act in the face of uncertainty, it would be beneficial to adopt a more expansive concept of "valid" empirical evidence that includes institutional investor preferences.

\section{External Governance}

Though I find some evidence of a mutual fund preference for annual director elections, the results of this study suggest that there is a high level of institutional tolerance (and, in some cases, a seeming preference) for investing in firms with low levels of takeover vulnerability. For example, in this study, I find a statistically significant relationship between public pension fund ownership and low-quality external governance, including the presence of a staggered board. These results may strike some as puzzling because many institutional investors, particularly public pension funds, are vocal opponents of antitakeover devices such as poison pills 
and staggered boards. However, this outcome is consistent with researcher Brandon Gold's findings that suggest institutional investor "hypocrisy" when it comes to antitakeover mechanisms. ${ }^{258}$

Over the past decade, pension funds and mutual funds have increasingly come out publicly in opposition to antitakeover devices, particularly staggered boards. ${ }^{259}$ For example, the five largest mutual funds, the Council of Institutional Investors, and the largest public pension funds have adopted formal policies to support annual director elections and oppose classified boards. ${ }^{260}$ In addition, as Professor Bebchuk notes, institutional investors, if assessed by voting record, firmly support director accountability and de-staggering of boards. ${ }^{261}$ He points to the voting decisions of institutional investors in the past three years and notes that shareholder proposals for S\&P 500 company board declassification have received, on average, more than $75 \%$ of the votes cast in favor. ${ }^{262}$ This fact must point to, Professor Bebchuk argues, the widespread belief among institutional investors that devices like staggered boards that facilitate management entrenchment are likely to be value decreasing, not value enhancing over the long term. ${ }^{263}$ This institutional support is not just from investors with generally short investment time horizons, Professor Bebchuk notes, but also from public pension funds (e.g., CalPERS, TIAA-CREF), investors with long-term horizons because of their need to use investments to meet long-term retirement obligations, as well as from private investment managers such as Vanguard, BlackRock, and State Street that focus on providing mutual funds that focus on passive, long-term investments. ${ }^{264}$ Professor Bebchuk goes on to argue that this consistent pattern of institutional investor support should

258 See Gold, supra note 24 , at 56.

259 Id. at 1.

260 Id. at 8-9.

261 Bebchuk, supra note 141, at 1681.

262 Id. at $1681-82$.

263 Id. at 1681.

264 Id. at 1682. 
give those who favor board insulation techniques such as staggered boards pause, as they should be reluctant to assert that they know what is in the long-term interests of investors better than the investors do. ${ }^{265}$

This de-staggering trend has occurred in the wake of shareholder activism, which often takes the form of shareholder proposals to de-classify boards. ${ }^{266}$ Many public companies consequently have de-staggered their boards: approximately sixty companies per year de-staggered their boards from 2003 to 2010, a substantial increase from the average of four firms per year de-staggering between 1987 and 2002. ${ }^{267}$ From 2000 to 2012, the number of S\&P 500 companies with classified boards declined by more than $40 \%{ }^{268}$ In the 2012 proxy season alone, the Harvard Shareholder Rights Project submitted shareholder proposals that led to declassification of one-third of the staggered boards in the S\&P $500 .{ }^{269}$ On average, $99 \%$ of the votes cast with respect to these proposals were in favor of declassification, which seems to suggest robust investor opposition to staggered boards. ${ }^{270}$ Moreover, firms that were subject to declassification proposals de-staggered their boards more frequently than firms that were not the targets of such proposals. ${ }^{271}$ The de-staggering trend has been helped by the presumption of ISS support for such proposals. ${ }^{272}$

Institutional investors' public opposition to low-quality external governance and the subsequent board de-staggering trend are at odds with the available evidence on IPO charter governance provisions. Charters of IPO firms generally are devoid of governance innovations, as companies typically adopt the default provisions of the corporate codes of their

265 Id. at 1683.

266 Gold, supra note 24, at 1.

267 Klausner, supra note 119 , at 1360.

268 Gold, supra note 24, at 9.

269 Id. at 9-10.

270 Id at 10.

271 Klausner, supra note 119 , at 1360.

272 Paul Rose, The Corporate Governance Industry, 32 J. Corp. L. 887, 909 (2007). 
states of incorporation. ${ }^{273}$ However, staggered boards are an exception. ${ }^{274}$ Despite the vocal opposition to antitakeover devices and the recent success of declassification efforts, most companies that go public have a staggered board in place. ${ }^{275}$ According to one report, as many as $86 \%$ of IPO firms (i.e., firms going public) have staggered boards in place. ${ }^{276}$ Another study of firms that went public between 1997 and 2005 revealed that approximately $64 \%$ of them had staggered board provisions in their charters. ${ }^{277}$ Similarly, in a review of the governance characteristics of firms at the time of IPO for the one hundred largest IPO's in the U.S. between September 2011 and October 2013, Davis Polk found that these firms had purportedly low-quality external governance. ${ }^{278}$ For example, among the forty-six noncontrolled firms, 70\% had staggered boards and required a supermajority vote for amending bylaws, 78\% prohibited stockholders from acting by written consent, and $98 \%$ authorized blank check preferred stock (which makes it easier for a board to unilaterally put in a poison pill). ${ }^{279}$ Despite the pressure from some shareholder groups and proxy advisory firms to modify governance practices, governance attributes seem to have no meaningful impact on the willingness of investors to participate in the offering at the IPO stage. ${ }^{280}$ Indeed, Davis Polk asserts that "IPO

273 Klausner, supra note 119 , at 1329.

274 Id.

275 Gold, supra note 24, at 1.

276 Id. at 10 .

277 E-mail from William C. Johnson, Assistant Professor, Sawyer Sch. of Bus., Suffolk Univ., to Michael Klausner, Professor, Stanford Law Sch. (Jan. 11, 2013), cited in Klausner, supra note 119, at 1333 n.29 (confirming the aggregated percentage of all IPO firms with staggered boards based on their dataset). See also Johnson et al., supra note 168.

278 See Richard J. Sandler, Governance Practices for IPO Companies: A Davis Polk Survey, Harv. L. Sch. F. On Corp. Governance \& Fin. ReG. (Feb. 3, 2014, 9:10 AM), http://corpgov.law.harvard.edu/2014/02/03/ governance-practices-for-ipo-companies-a-davis-polk-survey/, archived at http://perma.cc/SC5F-KJCJ.

279 Id

280 Id. 
companies can continue to tailor their governance practices to fit their individual preferences." 281

Researcher Brandon Gold notes that public pension funds are among the most vocal opponents of antitakeover devices, yet they quietly invest in companies at the IPO stage that have all the devices they publicly disparage. Issuers with mutual funds and pension funds, which are among the most vocal critics of staggered boards, as significant pre-IPO shareholders have the strongest takeover defenses in place when they go public. ${ }^{282}$ Gold attributes this inconsistency potentially to the separation of voting and investing functions in large institutional investors ${ }^{283}$ : non-portfolio management personnel (members of the "corporate governance" department) are often responsible for voting decisions and have no input on the investment decisions of the portfolio managers. ${ }^{284}$ Moreover, for those institutions that rely heavily on ISS recommendations for voting, there is no coordination whatsoever between ISS (the source of the proxy voting recommendations) and the investment personnel. ${ }^{285}$

Whereas Gold finds this effect with respect to IPO firms, I find that it applies to investments in mature companies as well. Using a data set of mature NYSE-traded companies, I find, consistent with expectations, that mutual fund ownership is associated with annual director elections. However, public pension fund ownership is not. The pooled OLS analysis reveals that public pension funds do not eschew investments in companies with staggered boards. Indeed, the presence of a staggered board is associated with higher levels of public pension fund ownership. Thus, it appears that pension funds have relatively high levels of investment in firms with classified boards, despite their public protestations against the device.

281 Id

282 Gold, supra note 24, at 2.

283 Id. at 56.

284 Id.

285 Id 
Some of the previously listed examples of institutional activism occurred after my study period ended in 2010, but there is no reason to believe that the disconnect between public opposition to staggered boards and investment choice stems only from a change in time period. The dawn of public pension fund activism was in 1985 with the creation of the Council of Institutional Investors, an institution devoted to fostering collective advocacy for shareholder rights. ${ }^{286}$ Activist investors have advocated for the removal of poison pills via shareholder proposal submission since $1987,{ }^{287}$ and their efforts continued throughout the 1980s and 1990s when investors sought broader improvements in external and internal governance. Activism in the early 2000s seemed to gain immense traction in the post-Enron era, when management seemed less willing to fight activist efforts because of the high cost of ignoring shareholder demands. ${ }^{288}$ According to one study of a sample of 620 non-binding governance-related shareholder proposals, boards acted upon only $16 \%$ of shareholder proposals receiving majority shareholder vote in 1997; that percentage stood at $40 \%$ in $2004 .^{289}$ For antitakeover device removal proposals, the respective percentages were $18.6 \%$ and $40.2 \%{ }^{290}$ In addition, increasing numbers of antitakeover device shareholder proposals that received majority shareholder support in 2002-2004 led many firms to remove their poison pills and

286 Stuart L. Gillan \& Laura T. Starks, The Evolution of Shareholder Activism in the United States, 19 J. ApPLIED CoRP. Fin. 55, 56 (2007).

287 See Sharon Marcil \& Peg O'Hara, Investor Responsibility Research Center, Voting by Institutional InVestors on Corporate Governance Issues IN THE 1987 Proxy SEASON 5 (1987).

288 See Yonca Ertimur, Fabrizio Ferri \& Stephen R. Stubben, Board of Directors' Responsiveness to Shareholders: Evidence from Shareholder Proposals, 16 J. CORP. Fin. 53, 64 (2010).

289 Id. at 54, 58 tbl.1.

$290 \mathrm{Id}$. at 58 tbl.1 (showing that $18.6 \%$ represents the rate of implementation of majority approved shareholder proposals from 19972001 , and $40.2 \%$ represents the rate from 2002-2004). 
de-stagger their boards. ${ }^{291}$ Consequently, shareholder activism is by no means a post-2010 phenomenon.

One potential explanation for the "hypocrisy" we see among public pension funds may simply reflect the difficulty such investors face in divesting stocks of firms employing antitakeover devices. One pension fund corporate governance director I interviewed said s/he had never heard of a pension fund selling a stock on the basis of corporate governance alone. ${ }^{292}$ Stocks are sold on account of poor financial performance because pension fund managers are trying to maximize returns on behalf of their pension beneficiaries. However, even if financial analysis does not suggest that a stock should be sold, a manager may still comply with her fiduciary duties and sell the stock so long as the sale does not negatively affect the portfolio. ${ }^{293}$ The manager needs to be

291 Randall S. Thomas \& James F. Cotter, Shareholder Proposals in the New Millennium: Shareholder Support, Board Response, and Market Reaction, 13 J. CORP. Fin. 368, 369 (2007).

292 Interview with anonymous pension fund corporate governance director (July 3, 2014).

293 See, e.g., Pub. Health Inst. Technical Assistance Legal Ctr., Educational Foundations AND Endowments Legal Standards For TOBACCO DivestMent 2 n.3 (2001), http://www.bhopal.net/old _studentsforbhopal_org/Assets/LegalDivestment.pdf, archived at http://perma.cc/UQA2-3X98 (quoting Memorandum from Ian D. Lanoff to the Cal. State Teachers Ret. Sys.' Inv. Comm., Regarding Points Concerning Investment and Divestment of Plan Assets in Conformity with Fiduciary Principles (Mar. 24, 2000)).

If the analysis whether it is prudent to invest in or hold a security yields an uncertain or positive result, a fiduciary may lawfully sell the security if it is not imprudent to do so. Under such circumstances, a fiduciary may lawfully choose to divest, provided that a financial and economic analysis performed by investment professionals uncovers a number of potential investment opportunities that are ostensibly equally advantageous from an economic perspective. In this way a fiduciary may lawfully implement the divestment plan because it satisfies fiduciary requirements of loyalty to plan participants ... and prudence.

Id. 
able to replace the divested stock with a comparable security that is "equally advantageous from an economic perspective" so that the plan upholds its duty of loyalty to plan participants. ${ }^{294}$ It is much easier to divest a company's stock due, say, to politically controversial business relationships than it is to divest a stock because it has a staggered boardstaggered boards are simply too prevalent. Almost $12 \%$ of the firms in the S\&P 500, ${ }^{295} 40 \%$ of the S\&P $1500^{296}$ and $48 \%$ of the firms in my sample have classified boards. Even if a manager feels strongly about the absence of staggered boards as a matter of principle, unless she can tie the presence of staggered boards to poor financial performance in her portfolio, full-scale divestment of companies with staggered boards would be quite difficult. ${ }^{297}$

The foregoing provides a potential explanation for why pension funds do not divest the stocks of companies with staggered boards. What it does not explain is why there is a correlation between presence of a staggered board and higher levels of public pension fund ownership. The reason for this may be related to higher expected long-term performance of firms with staggered boards. Recall that Professors Cremers, Litov, and Sepe find an association between staggered boards and higher long-term firm value, ${ }^{298}$ so investing in firms with staggered boards could be a rational investment choice.

Relatedly, public pension funds' apparent preference for firms that employ antitakeover devices may also reflect the

$294 I d$

295 See Hoffman, supra note 170.

296 Becky Yerak, Staggered Boards: Public Companies' Directors the Centerpiece of a Tug of War, ChICAGo TRIBUne (Apr. 4, 2012), http://articles.chicagotribune.com/2012-04-04/business/ct-biz-0401-bfstaggered-boards-20120401_1_board-structure-board-members-boardterms, archived at http://perma.cc/7LUZ-EDV6.

297 It is interesting to note that when pension fund corporate governance professionals take on issues surrounding corporate governance, they typically do not use the threat of selling their stock as leverage against corporate management. Instead, they use other means of shareholder action such as voting against management on key proposals (e.g., say-on-pay).

298 See supra notes 171-174 and accompanying text. 
belief that high-quality external governance is costly. As discussed above, many internal governance improvements (e.g., replacing inside directors with outside directors) are relatively inexpensive. So, too, is improving external governance (e.g., de-staggering a board) for those firms that are not particularly vulnerable to takeovers. However, for those companies that are vulnerable to hostile activity (e.g., those that are undervalued relative to peers, have excess cash or debt capacity, have a shareholder base likely to support an unfriendly bid, ${ }^{299}$ are not too small to be worth the expense of a hostile bid $^{300}$ but not so large as to make acquisition infeasible, ${ }^{301}$ and have viable potential bidders that could achieve synergies through a business combination), ${ }^{302}$ de-staggering the board has the potential to be game-changing. Reasonable people can and do disagree about when and under what circumstances companies should allow themselves to be open to hostile attack. This study suggests that institutional investors, as a group, are quite comfortable with antitakeover devices, perhaps because these defenses can protect portfolio companies against opportunistic takeover attempts that take advantage of, for example, temporary stock price declines. ${ }^{303}$ This scenario is

299 See 13D Monitor, supra note 211.

300 See, e.g., In re Netsmart Tech., Inc. S'holder Litig., 924 A.2d 171, 178-79 (Del. Ch. 2007).

301 See, e.g., Paramount Commc'ns, Inc. v. Time Inc., 571 A.2d 1140, 1151 (Del. 1989).

302 See Michal Barzuza, Noise Adopters in Corporate Governance, 2013 Colum. Bus. L. Rev. 627, 640-41 (2013).

303 See, e.g., Air Products \& Chemicals, Inc. v. Airgas, Inc., 16 A.3d 48, 86 (Del. Ch. 2011). Air Products waged a 16-month hostile campaign to acquire Airgas, but ultimately failed in its attempts to remove Airgas' antitakeover devices. The Airgas board insisted that Air Products was undervaluing Airgas and attributed Airgas' recent share price drop to the poor economy. Within less than a year of Air Products dropping its bid, the Airgas stock price exceeded Air Product's "best and final offer" of $\$ 70$. See Historical Prices, YAHOO! FINANCE, http://finance.yahoo.com/q/hp?s= ARG\&a $=00 \& b=17 \& \mathrm{c}=2012 \& \mathrm{~d}=00 \& \mathrm{e}=17 \& \mathrm{f}=2012 \& \mathrm{~g}=\mathrm{d}, \quad$ archived at http://perma.cc/G49H-EHLL (last visited Nov. 26, 2014). As of March 23, 2015, Airgas was trading at \$105.31. ARG: Summary for Airgas, Inc. 
likely to be particularly true with respect to companies at the time they go public. ${ }^{304}$

What is clear is that there is a positive relationship between public pension fund ownership and the presence of antitakeover devices. Given this fact, I submit that before we criticize legislators or courts for impeding the market for corporate control by making it easier for boards to resist hostile activity and going against the weight of empirical evidence when doing so, one might want to consider the role that institutional investor preferences play in the perpetuation of antitakeover devices. Despite the claim by many academic researchers that exposure to the market for corporate control is an unequivocal good, many institutional investors, based on their ownership stakes, appear to have a different or at least a more nuanced view.

\section{CONCLUSION}

This Article offers evidence that higher quality internal corporate governance is associated with higher levels of ownership by institutional investors. This finding is consistent with the idea that institutions have greater reasons than individual investors to prefer well-governed firms, but somewhat surprising given the decidedly mixed empirical evidence on the efficacy of internal governance mechanisms. The study also finds that higher quality external governance is associated, in many cases, with lower proportions of ownership by institutional investors. This discovery also is a surprising result given empirical evidence on the positive relationship between external governance and

Common Stock, YAHOO! FINANCE, http://finance.yahoo.com/q?s=ARG, archived at http://perma.cc/YYN6-VSAT (last visited Mar. 23, 2015).

304 In an interview with a director of corporate governance at a pension fund, I learned that the issue of staggered boards at the time of the IPO was raised at an institutional investor conference s/he attended recently. The emerging consensus in the room, I am told, was that there is some virtue in giving relatively young companies the space to grow and develop without risk of an ill-timed and opportunistic hostile takeover. Interview with anonymous pension fund corporate governance director, supra note 292 . 
firm performance. After largely dismissing competing explanations for these findings, I conclude that institutional investors simply prefer internal governance mechanisms and, at a minimum, tolerate and may even prefer purportedly low-quality external governance. I further make the rather modest suggestion that when debating the efficacy of governance mechanisms, the preferences of informed, sophisticated investors be afforded greater weight than is currently the case.

When accepting the Nobel Prize for Economics, Professor Bob Solow remarked:

[Economists] should try very hard to be scientific with a small s. By that I mean only that we should think logically and respect fact. ... Now, I want to say something about fact. The austere view is that "facts" are just time series of prices and quantities. The rest is all hypothesis testing. I have seen a lot of those tests. They are almost never convincing, primarily because one senses that they have very low power against lots of alternatives. There are too many ways to explain a bunch of time series. . . . My hunch is that we can make progress only by enlarging the class of eligible facts to include, say, the opinions and casual generalizations of experts and market participants, attitudinal surveys, institutional regularities, even our own judgments of plausibility. ${ }^{305}$

These words of wisdom can be applied in the context of empirical research surrounding corporate governance. Setting corporate law policy is unquestionably a difficult endeavor, as there are hundreds of studies reaching inconsistent conclusions about what "works" in corporate governance. "Enlarging the class of eligible facts" to include the reasoned preferences of the protected class may allow us

305 Robert Solow, Lives of the Laureates 168-69 (William Breit \& Barry T. Hirsch eds., 5th ed. 2009), cited in Stephen T. Ziliak \& Deirdre N. McCloskey, Size Matters: The Standard Error of Regressions in the American Economic Review, 33 J. SocIO-Econ. 527, 544 (2004). 
to move closer to making the progress of which Professor Solow speaks. 
APPENDIX

TABLE 1: SUMMARY STATISTICS ${ }^{306}$

\begin{tabular}{|lllll|}
\hline $\begin{array}{l}\text { Dependent } \\
\text { Variables }\end{array}$ & & Overall & Between & Within \\
\hline $\begin{array}{l}\text { Overall } \\
\text { Institutional } \\
\text { Ownership }\end{array}$ & Mean & 0.705 & & \\
& Std. Dev. & 0.232 & 0.198 & 0.126 \\
& Minimum & 0.000 & 0.003 & -0.105 \\
& Maximum & 2.973 & 1.631 & 3.124 \\
& Observations/ & 11,801 & 1,470 & 8.028 \\
\hline Bank & Mean & 0.167 & & \\
Ownership & Std. Dev. & 0.081 & 0.063 & 0.052 \\
& Minimum & 0.000 & 0.000 & -0.148 \\
& Maximum & 2.133 & 0.712 & 1.947 \\
& Observations/ & 11,803 & 1,470 & 8.029 \\
& T-bar & & & \\
\hline
\end{tabular}

306 Table 1 reports summary data on the variables used in the analysis of the relationship between institutional ownership and corporate governance. Higher values of "ISS INDEX CGQ," ISS INDUSTRY CGQ," and "ISS INTERNAL GOVERNANCE SCORE" reflect higher quality (primarily or exclusively) internal governance (e.g., board independence). Higher values of " $E-I N D E X$ " and " $G$-INDEX" reflect lower quality external governance (i.e., less exposure to the market for corporate control). Lower values of "ISS EXTERNAL GOVERNANCE SCORE" represent lower quality external governance. "ANNUAL DIRECTOR ELECTIONS (i.e., no staggered board)" is a measure of high-quality external governance. "Observations" in the "Overall" column represents the total number of firm-years in the panel. "Observations" in the "Between" column represents the number of firms. "T-bar" figures in the "Within" column represent the average number of years a firm was observed in the applicable variable category. The "Minimums" and "Maximums" reported under the "Overall" column represent the range of values for the overall sample. Those reported under the "Between" column represent the range of values across firms. The "Minimums" and "Maximums" reported under the "Within" column represent the range of deviations from each individual firm's average for the applicable variable, which may result in negative values. 
TABLE 1: SUMMARY STATISTICS (CONT.)

\begin{tabular}{|c|c|c|c|c|}
\hline $\begin{array}{l}\text { Dependent } \\
\text { Variables }\end{array}$ & & Overall & Between & Within \\
\hline \multirow{5}{*}{$\begin{array}{l}\text { Insurance } \\
\text { Company } \\
\text { Ownership }\end{array}$} & Mean & 0.038 & & \\
\hline & Std. Dev. & 0.041 & 0.034 & 0.024 \\
\hline & Minimum & 0.000 & 0.000 & -0.452 \\
\hline & Maximum & 0.695 & 0.646 & 0.305 \\
\hline & $\begin{array}{l}\text { Observations/ } \\
\text { T-bar }\end{array}$ & 11,803 & 1,470 & 8.029 \\
\hline \multirow{5}{*}{$\begin{array}{l}\text { Mutual } \\
\text { Fund } \\
\text { Ownership }\end{array}$} & Mean & 0.452 & & \\
\hline & Std. Dev. & 0.177 & 0.150 & 0.096 \\
\hline & Minimum & 0.000 & 0.000 & -0.180 \\
\hline & Maximum & 1.588 & 1.063 & 1.256 \\
\hline & $\begin{array}{l}\text { Observations/ } \\
\text { T-bar }\end{array}$ & 11,803 & 1,470 & 8.029 \\
\hline \multirow{5}{*}{$\begin{array}{l}\text { Corporate } \\
\text { Pension } \\
\text { Fund } \\
\text { Ownership }\end{array}$} & Mean & 0.007 & & \\
\hline & Std. Dev. & 0.033 & 0.030 & 0.012 \\
\hline & Minimum & 0.000 & 0.000 & -0.259 \\
\hline & Maximum & 0.913 & 0.902 & 0.442 \\
\hline & $\begin{array}{l}\text { Observations/ } \\
\text { T-bar }\end{array}$ & 11,803 & 1,470 & 8.029 \\
\hline \multirow{5}{*}{$\begin{array}{l}\text { Public } \\
\text { Pension } \\
\text { Fund } \\
\text { Ownership }\end{array}$} & Mean & 0.025 & & \\
\hline & Std. Dev. & 0.015 & 0.012 & 0.009 \\
\hline & Minimum & 0.000 & 0.000 & -0.050 \\
\hline & Maximum & 0.188 & 0.162 & 0.148 \\
\hline & $\begin{array}{l}\text { Observations/ } \\
\text { T-bar }\end{array}$ & 11,803 & 1,470 & 8.029 \\
\hline \multirow{5}{*}{$\begin{array}{l}\text { University/ } \\
\text { Foundation } \\
\text { Endowment } \\
\text { Ownership }\end{array}$} & Mean & 0.002 & & \\
\hline & Std. Dev. & 0.007 & 0.005 & 0.005 \\
\hline & Minimum & 0.000 & 0.000 & -0.063 \\
\hline & Maximum & 0.149 & 0.131 & 0.100 \\
\hline & $\begin{array}{l}\text { Observations/ } \\
\text { T-bar }\end{array}$ & 11,803 & 1,470 & 8.029 \\
\hline
\end{tabular}


No. 1:1]

TABLE 1: SUMMARY STATISTICS (CONT.)

\begin{tabular}{|c|c|c|c|c|}
\hline $\begin{array}{l}\text { Dependent } \\
\text { Variables }\end{array}$ & & Overall & Between & Within \\
\hline \multirow{5}{*}{$\begin{array}{l}\text { Other } \\
\text { Institutional } \\
\text { Ownership }\end{array}$} & Mean & 0.029 & & \\
\hline & Std. Dev. & 0.037 & 0.025 & 0.027 \\
\hline & Minimum & 0.000 & 0.000 & -0.180 \\
\hline & Maximum & 0.729 & 0.251 & 0.673 \\
\hline & $\begin{array}{l}\text { Observations/ } \\
\text { T-bar }\end{array}$ & 11,803 & 1,470 & 8.029 \\
\hline $\begin{array}{l}\text { Independent } \\
\text { Variables } \\
\text { of Interest }\end{array}$ & & Overall & Between & Within \\
\hline \multirow{5}{*}{$\begin{array}{l}\text { ISS } \\
\text { Index } \\
\text { CGQ }\end{array}$} & Mean & 56.651 & & \\
\hline & Std. Dev. & 28.398 & 21.544 & 18.681 \\
\hline & Minimum & 0.100 & 1.739 & -23.935 \\
\hline & Maximum & 100.000 & 99.182 & 122.091 \\
\hline & $\begin{array}{l}\text { Observations/ } \\
\text { T-bar }\end{array}$ & 10,437 & 1,348 & 7.743 \\
\hline \multirow{5}{*}{$\begin{array}{l}\text { ISS } \\
\text { Industry } \\
\text { CGQ }\end{array}$} & Mean & 70.006 & & \\
\hline & Std. Dev. & 24.705 & 19.293 & 15.880 \\
\hline & Minimum & 0.170 & 3.743 & -8.861 \\
\hline & Maximum & 100.000 & 99.138 & 130.762 \\
\hline & $\begin{array}{l}\text { Observations/ } \\
\text { T-bar }\end{array}$ & 10,437 & 1,348 & 7.743 \\
\hline \multirow{5}{*}{$\begin{array}{l}\text { ISS } \\
\text { Internal }\end{array}$} & Mean & 22.762 & & \\
\hline & Std. Dev. & 7.185 & 2.691 & 6.714 \\
\hline & Minimum & 4.000 & 11.000 & -0.238 \\
\hline & Maximum & 39.000 & 31.000 & 36.429 \\
\hline & $\begin{array}{l}\text { Observations/ } \\
\text { T-bar }\end{array}$ & 10,437 & 1,348 & 7.743 \\
\hline \multirow[t]{5}{*}{ E-Index } & Mean & 2.736 & & \\
\hline & Std. Dev. & 1.227 & 1.022 & 0.732 \\
\hline & Minimum & 0.000 & 0.000 & -0.764 \\
\hline & Maximum & 6.000 & 6.000 & 5.861 \\
\hline & $\begin{array}{l}\text { Observations/ } \\
\text { T-bar }\end{array}$ & 8,080 & 1,210 & 6.678 \\
\hline
\end{tabular}


TABLE 1: SUMMARY STATISTICS (CONT.)

\begin{tabular}{|c|c|c|c|c|}
\hline $\begin{array}{l}\text { Independent } \\
\text { Variables } \\
\text { of Interest } \\
\end{array}$ & & Overall & Between & Within \\
\hline \multirow[t]{5}{*}{ G-Index } & Mean & 9.437 & & \\
\hline & Std. Dev. & 2.568 & 2.533 & 0.424 \\
\hline & Minimum & 2.000 & 2.000 & 4.771 \\
\hline & Maximum & 18.000 & 18.000 & 12.437 \\
\hline & $\begin{array}{l}\text { Observations/ } \\
\text { T-bar }\end{array}$ & 5,991 & 1,143 & 5.241 \\
\hline \multirow{5}{*}{$\begin{array}{l}\text { ISS } \\
\text { External }\end{array}$} & Mean & 7.574 & & \\
\hline & Std. Dev. & 2.8810 & 2.072 & 2.023 \\
\hline & Minimum & 0.000 & 1.667 & -2.301 \\
\hline & Maximum & 16.000 & 14.000 & 14.240 \\
\hline & $\begin{array}{l}\text { Observations/ } \\
\text { T-bar }\end{array}$ & 10,437 & 1,348 & 7.743 \\
\hline \multirow{5}{*}{$\begin{array}{l}\text { Annual } \\
\text { Director } \\
\text { Elections }\end{array}$} & Mean & 0.444 & & \\
\hline & Std. Dev. & 0.497 & 0.468 & 0.169 \\
\hline & Minimum & 0.000 & 0.000 & -0.445 \\
\hline & Maximum & 1.000 & 1.000 & 1.333 \\
\hline & $\begin{array}{l}\text { Observations/ } \\
\text { T-bar }\end{array}$ & 10,803 & 1,348 & 8.014 \\
\hline $\begin{array}{l}\text { Control } \\
\text { Variables }\end{array}$ & & Overall & Between & Within \\
\hline \multirow{5}{*}{$\begin{array}{l}\text { Delaware } \\
\text { Incorp. }\end{array}$} & Mean & 0.559 & & \\
\hline & Std. Dev. & 0.497 & 0.492 & 0.064 \\
\hline & Minimum & 0.000 & 0.000 & -0.219 \\
\hline & Maximum & 1.000 & 1.000 & 1.226 \\
\hline & $\begin{array}{l}\text { Observations/ } \\
\text { T-bar }\end{array}$ & 9,158 & 1,210 & 7.569 \\
\hline \multirow{5}{*}{$\begin{array}{l}\text { Irregularity } \\
\text { Restatement } \\
\text { History }\end{array}$} & Mean & 0.012 & & \\
\hline & Std. Dev. & 0.107 & 0.049 & 0.097 \\
\hline & Minimum & 0.000 & 0.000 & -0.655 \\
\hline & Maximum & 1.000 & 0.667 & 0.900 \\
\hline & $\begin{array}{l}\text { Observations/ } \\
\text { T-bar }\end{array}$ & 11,804 & 1,470 & 8.030 \\
\hline
\end{tabular}


No. 1:1]

TABLE 1: SUMMARY STATISTICS (CONT.)

\begin{tabular}{|c|c|c|c|c|}
\hline \multicolumn{2}{|l|}{$\begin{array}{l}\text { Control } \\
\text { Variables }\end{array}$} & \multirow{2}{*}{$\begin{array}{l}\text { Overall } \\
8,033.458\end{array}$} & \multirow[t]{2}{*}{ Between } & \multirow[t]{2}{*}{ Within } \\
\hline \multirow{5}{*}{$\begin{array}{l}\text { Market } \\
\text { Capital- } \\
\text { ization } \\
\text { (mean, min, } \\
\text { max in } \\
\text { millions) }\end{array}$} & Mean & & & \\
\hline & Std. Dev. & $23,401.94$ & $21,240.95$ & $7,357.087$ \\
\hline & Minimum & 1.756 & 5.910 & $-186,458.800$ \\
\hline & Maximum & $452,505.300$ & $343,599.000$ & $145,098.700$ \\
\hline & $\begin{array}{l}\text { Observations/ } \\
\text { T-bar }\end{array}$ & 11,800 & 1,470 & 8.02721 \\
\hline \multirow{5}{*}{$\begin{array}{l}\text { Average } \\
\text { Daily } \\
\text { Trading } \\
\text { Volume }\end{array}$} & Mean & $1,710,659.000$ & & \\
\hline & Std. Dev. & $7,064,189.000$ & $4,304,473.000$ & $5,522,876.000$ \\
\hline & Minimum & $3,313.834$ & $11,652.060$ & $-81,800,000.000$ \\
\hline & Maximum & $499,000,000.000$ & $96,400,000.000$ & $404,000,000.000$ \\
\hline & $\begin{array}{l}\text { Observations/ } \\
\text { T-bar }\end{array}$ & 11,751 & 1,469 & 7.999 \\
\hline \multirow{5}{*}{$\begin{array}{l}\text { Research } \\
\text { Coverage } \\
\text { (number of } \\
\text { analysts } \\
\text { covering at a } \\
\text { point in time) }\end{array}$} & Mean & 9.356 & & \\
\hline & Std. Dev. & 6.808 & 6.318 & 2.501 \\
\hline & Minimum & 1.000 & 1.000 & -14.444 \\
\hline & Maximum & 42.000 & 32.556 & 27.356 \\
\hline & $\begin{array}{l}\text { Observations/ } \\
\text { T-bar }\end{array}$ & 11,217 & 1,445 & 7.7626 \\
\hline \multirow{5}{*}{$\begin{array}{l}\text { Research } \\
\text { Activity } \\
\text { (number of } \\
\text { earnings } \\
\text { estimates } \\
\text { published in } \\
\text { a year) }\end{array}$} & Mean & 314.685 & & \\
\hline & Std. Dev. & 300.923 & 266.942 & 130.130 \\
\hline & Minimum & 1.000 & 2.000 & -565.565 \\
\hline & Maximum & $2,533.000$ & $1,842.222$ & $1,478.560$ \\
\hline & $\begin{array}{l}\text { Observations/ } \\
\text { T-bar }\end{array}$ & 11,327 & 1,445 & 7.839 \\
\hline \multirow{5}{*}{$\begin{array}{l}\text { Industry } \\
\text { Diversity } \\
\text { (1= operates } \\
\text { in more than } \\
\text { two } \\
\text { industries) }\end{array}$} & Mean & 0.580 & & \\
\hline & Std. Dev. & 0.494 & 0.495 & 0.000 \\
\hline & Minimum & 0.000 & 0.000 & 0.580 \\
\hline & Maximum & 1.000 & 1.000 & 0.580 \\
\hline & $\begin{array}{l}\text { Observations/ } \\
\text { T-bar }\end{array}$ & 10,751 & 1,318 & 8.157 \\
\hline \multirow{5}{*}{$\begin{array}{l}\text { News } \\
\text { Story } \\
\text { Mentions }\end{array}$} & Mean & 173.559 & & \\
\hline & Std. Dev. & 525.034 & 469.512 & 201.466 \\
\hline & Minimum & 0.000 & 0.111 & $-4,162.108$ \\
\hline & Maximum & 17,241 & $9,237.667$ & $8,176.892$ \\
\hline & $\begin{array}{l}\text { Observations/ } \\
\text { T-bar }\end{array}$ & 11,799 & 1,469 & 8.032 \\
\hline
\end{tabular}


TABLE 1: SUMMARY STATISTICS (CONT.)

\begin{tabular}{|c|c|c|c|c|}
\hline $\begin{array}{l}\text { Control } \\
\text { Variables }\end{array}$ & & Overall & Between & Within \\
\hline \multirow{5}{*}{$\begin{array}{l}\text { Age } \\
\text { (in months) }\end{array}$} & Mean & 296.577 & & \\
\hline & Std. Dev. & 242.058 & 238.512 & 28.0876 \\
\hline & Minimum & 0.000 & 2.000 & 250.827 \\
\hline & Maximum & $1,011.000$ & 969.000 & 352.291 \\
\hline & $\begin{array}{l}\text { Observations/ } \\
\text { T-bar }\end{array}$ & 11,779 & 1,470 & 8.013 \\
\hline \multirow{5}{*}{$\begin{array}{l}\text { Volatility } \\
\text { (standard } \\
\text { deviation of } \\
\text { monthly } \\
\text { returns) }\end{array}$} & Mean & 0.103 & & \\
\hline & Std. Dev. & 0.071 & 0.039 & 0.060 \\
\hline & Minimum & 0.007 & 0.032 & -0.091 \\
\hline & Maximum & 1.039 & 0.265 & 0.961 \\
\hline & $\begin{array}{l}\text { Observations/ } \\
\text { T-bar }\end{array}$ & 11,722 & 1,469 & 7.980 \\
\hline \multirow{5}{*}{$\begin{array}{l}\text { Return-on- } \\
\text { equity } \\
\text { (in integers) }\end{array}$} & Mean & 0.149 & & \\
\hline & Std. Dev. & 2.829 & 0.978 & 2.644 \\
\hline & Minimum & -43.475 & -5.203 & -38.123 \\
\hline & Maximum & 225.581 & 28.345 & 197.385 \\
\hline & $\begin{array}{l}\text { Observations/ } \\
\text { T-bar }\end{array}$ & 8,981 & 1,197 & 7.503 \\
\hline \multirow{5}{*}{$\begin{array}{l}\text { Dividends- } \\
\text { to-equity } \\
\text { (in integers) }\end{array}$} & Mean & 0.053 & & \\
\hline & Std. Dev. & 0.748 & 0.276 & 0.696 \\
\hline & Minimum & -23.483 & -1.936 & -21.494 \\
\hline & Maximum & 38.690 & 6.003 & 33.907 \\
\hline & $\begin{array}{l}\text { Observations/ } \\
\text { T-bar }\end{array}$ & 7,323 & 1,174 & 6.238 \\
\hline \multirow{5}{*}{$\begin{array}{l}\text { Tangible } \\
\text { Assets-to- } \\
\text { Total Assets } \\
\text { (in integers) }\end{array}$} & Mean & 29.280 & & \\
\hline & Std. Dev. & 25.450 & 24.583 & 6.826 \\
\hline & Minimum & 0.000 & 0.000 & -48.485 \\
\hline & Maximum & 99.788 & 92.901 & 67.415 \\
\hline & $\begin{array}{l}\text { Observations/ } \\
\text { T-bar }\end{array}$ & 9,151 & 1,115 & 8.207 \\
\hline
\end{tabular}


No. 1:1]

TABLE 1: SUMMARY STATISTICS (CONT.)

\begin{tabular}{|c|c|c|c|c|}
\hline $\begin{array}{l}\text { Control } \\
\text { Variables }\end{array}$ & & Overall & Between & Within \\
\hline \multirow[t]{5}{*}{ Stock Price } & Mean & 33.343 & & \\
\hline & Std. Dev. & 34.151 & 29.153 & 16.051 \\
\hline & Minimum & 0.080 & 0.270 & -283.9901 \\
\hline & Maximum & 894.000 & 674.433 & 359.4871 \\
\hline & $\begin{array}{l}\text { Observations/ } \\
\text { T-bar }\end{array}$ & 11,801 & 1,470 & 8.028 \\
\hline \multirow{5}{*}{$\begin{array}{l}\text { Sales } \\
\text { Growth } \\
\text { (in integers) }\end{array}$} & Mean & 9.687 & & \\
\hline & Std. Dev. & 99.340 & 32.369 & 93.507 \\
\hline & Minimum & -284.814 & -84.121 & $-1,114.075$ \\
\hline & Maximum & $9,259.818$ & $1,025.217$ & $8,244.289$ \\
\hline & $\begin{array}{l}\text { Observations/ } \\
\text { T-bar }\end{array}$ & 9,634 & 1,193 & 8.075 \\
\hline \multirow{5}{*}{$\begin{array}{l}\text { Book-to- } \\
\text { Market } \\
\text { Equity } \\
\text { (in integers) }\end{array}$} & Mean & 50.328 & & \\
\hline & Std. Dev. & 93.862 & 53.224 & 77.740 \\
\hline & Minimum & $-5,397.792$ & -815.340 & -4532.124 \\
\hline & Maximum & $1,293.19$ & 379.235 & $1,099.666$ \\
\hline & $\begin{array}{l}\text { Observations/ } \\
\text { T-bar }\end{array}$ & 8,432 & 1,194 & 7.062 \\
\hline \multirow{5}{*}{$\begin{array}{l}\text { S\&P } 500 \\
\text { Member }\end{array}$} & Mean & 0.269 & & \\
\hline & Std. Dev. & 0.444 & 0.415 & 0.138 \\
\hline & Minimum & 0.000 & 0.000 & -0.620 \\
\hline & Maximum & 1.000 & 1.000 & 1.158 \\
\hline & $\begin{array}{l}\text { Observations/ } \\
\text { T-bar }\end{array}$ & 11,804 & 1,470 & 8.030 \\
\hline
\end{tabular}


TABLE 2:

\begin{tabular}{|c|c|c|c|c|c|c|c|c|}
\hline & $\begin{array}{l}\text { Inst. } \\
\text { Own. }\end{array}$ & $\begin{array}{l}\text { Bank } \\
\text { Own. }\end{array}$ & $\begin{array}{c}\text { Ins. Co. } \\
\text { Own. }\end{array}$ & $\begin{array}{l}\text { Mutual } \\
\text { Fund } \\
\text { Own. }\end{array}$ & $\begin{array}{l}\text { Corp. } \\
\text { Pension } \\
\text { Fund } \\
\text { Own. }\end{array}$ & $\begin{array}{c}\text { Public } \\
\text { Pension } \\
\text { Fund } \\
\text { Own. }\end{array}$ & $\begin{array}{c}\text { Uni/ } \\
\text { Foun } \\
\text { Endow. } \\
\text { Own. }\end{array}$ & $\begin{array}{c}\text { Other } \\
\text { Inst. } \\
\text { Own. }\end{array}$ \\
\hline $\begin{array}{l}\text { Inst. } \\
\text { Own. }\end{array}$ & 1.000 & & & & & & & \\
\hline $\begin{array}{l}\text { Bank } \\
\text { Own. }\end{array}$ & $0.562+$ & 1.000 & & & & & & \\
\hline $\begin{array}{l}\text { Ins. Co. } \\
\text { Own. }\end{array}$ & $0.249 \neq$ & 0.108 & 1.000 & & & & & \\
\hline $\begin{array}{l}\text { Mut. } \\
\text { Fund }\end{array}$ & $0.874+$ & 0.244 & $0.052+$ & 1.000 & & & & \\
\hline $\begin{array}{l}\text { Own. } \\
\text { Corp. } \\
\text { Pens. }\end{array}$ & $0.098+$ & $-0.031 \ddagger$ & $-0.019 \dagger$ & $-0.033 \neq$ & 1.000 & & & \\
\hline $\begin{array}{l}\text { Own. } \\
\text { Pub. } \\
\text { Pens. }\end{array}$ & $0.363 \ddagger$ & $0.324+$ & $0.154 \ddagger$ & $0.232 \ddagger$ & $-0.027 \ddagger$ & 1.000 & & \\
\hline $\begin{array}{l}\text { Own. } \\
\text { Uni/Foun } \\
\text { Own. }\end{array}$ & $0.099 \ddagger$ & 0.000 & -0.000 & $0.085 \ddagger$ & 0.008 & 0.009 & 1.000 & \\
\hline $\begin{array}{l}\text { Other } \\
\text { Inst. }\end{array}$ & $0.286+$ & $0.045 \neq$ & $-0.047+$ & $0.154 \ddagger$ & -0.001 & 0.012 & $0.032+$ & 1.000 \\
\hline $\begin{array}{l}\text { Own. } \\
\text { Index } \\
\text { CGQ }\end{array}$ & $0.076 \neq$ & $0.034 \div$ & 0.004 & $0.083 \ddagger$ & $-0.024 \dagger$ & $-.022 \dagger$ & -0.008 & 0.013 \\
\hline $\begin{array}{l}\text { Industry } \\
\text { CGQ }\end{array}$ & $0.241+$ & $0.222+$ & $0.043 \ddagger$ & $0.156 \ddagger$ & $-0.046 \ddagger$ & $0.169 \$$ & 0.014 & $0.095 \ddagger$ \\
\hline $\begin{array}{l}\text { ISS } \\
\text { Internal }\end{array}$ & $0.162 \neq$ & $0.139 \neq$ & 0.007 & $0.107 \ddagger$ & $-0.030 \ddagger$ & 0.006 & 0.006 & $0.123+$ \\
\hline E-Index & $0.068+$ & $0.047+$ & -0.011 & $0.059 \ddagger$ & $-0.076 \ddagger$ & $0.052 \ddagger$ & 0.015 & $0.021^{*}$ \\
\hline $\begin{array}{l}\text { G-Index } \\
\text { ISS } \\
\text { External }\end{array}$ & $\begin{array}{l}-.029 \dagger \\
0.062 \ddagger\end{array}$ & $\begin{array}{c}0.059 \neq \\
-0.013\end{array}$ & $\begin{array}{l}0.027 \dagger \\
-0.006\end{array}$ & $\begin{array}{c}-0.057 \ddagger \\
0.064 \ddagger\end{array}$ & $\begin{array}{c}-0.060 \ddagger \\
0.052 \ddagger\end{array}$ & $\begin{array}{c}0.164 \ddagger \\
-0.133 \$\end{array}$ & $\begin{array}{c}-0.022^{*} \\
-0.016\end{array}$ & $\begin{array}{r}-0.053 \$ \\
0.087 \$\end{array}$ \\
\hline $\begin{array}{l}\text { Ann. Dir. } \\
\text { Elec. }\end{array}$ & $0.026 \neq$ & 0.008 & 0.025 & 0.008 & $0.051+$ & $-.051 \ddagger$ & -0.015 & $0.032+$ \\
\hline $\begin{array}{l}\text { Del. } \\
\text { Incorp. }\end{array}$ & $0.171 \neq$ & $0.068 \neq$ & $0.042 \ddagger$ & $0.157 \ddagger$ & $0.021 \dagger$ & 0.003 & 0.003 & 0.051 \$ \\
\hline $\begin{array}{l}\text { Irreg. } \\
\text { Restmt }\end{array}$ & $0.025+$ & 0.002 & -0.006 & $0.026 \ddagger$ & 0.012 & 0.015 & -0.002 & 0.010 \\
\hline $\begin{array}{l}\text { Market } \\
\text { Cap }\end{array}$ & $-0.087 \ddagger$ & $0.095+$ & $0.049 \ddagger$ & -0.175 本 & 0.006 & $0.062 \ddagger$ & 0.027 & -0.030 \\
\hline $\begin{array}{l}\text { Trading } \\
\text { Vol. }\end{array}$ & $-0.023 \dagger$ & $0.033 \neq$ & $0.020 \dagger$ & -0.055 末 & -0.004 & $0.020 \dagger$ & -0.004 & -0.002 \\
\hline Res. Cov. & 0.120 \& & $0.233 \neq$ & $0.111 \ddagger$ & 0.002 & 0.014 & $0.180 \ddagger$ & $0.030^{\dagger}$ & $-0.022 \dagger$ \\
\hline $\begin{array}{l}\text { Res. } \\
\text { Activity }\end{array}$ & $0.157+$ & $0.199+$ & $0.080 \ddagger$ & $0.062 \ddagger$ & $0.025 \dagger$ & $0.123 \ddagger$ & $0.016^{*}$ & $0.020 \dagger$ \\
\hline $\begin{array}{l}\text { Ind. } \\
\text { Diversity }\end{array}$ & $-0.020 \dagger$ & $0.057 \ddagger$ & -0.000 & $-0.054+$ & 0.011 & $0.083 \$$ & $-0.062 \ddagger$ & $-0.024 \dagger$ \\
\hline $\begin{array}{l}\text { News } \\
\text { Stories }\end{array}$ & $-0.063 \ddagger$ & $0.074+$ & $0.030 \ddagger$ & $-0.127+$ & -0.013 & $0.056 \ddagger$ & -0.007 & $-0.021 \dagger$ \\
\hline Age & 0.002 & $0.182 \ddagger$ & $0.055 \ddagger$ & -0.100 廿 & -0.012 & $0.221 \ddagger$ & $-0.050+$ & -0.055 \\
\hline $\begin{array}{l}\text { Volatility } \\
\text { Ret.-on- } \\
\text { Equity }\end{array}$ & $\begin{array}{c}-0.032+ \\
-0.006\end{array}$ & $\begin{array}{c}-0.087 \ddagger \\
-0.004\end{array}$ & $\begin{array}{c}-0.079+ \\
0.002\end{array}$ & $\begin{array}{l}0.030 \ddagger \\
-0.008\end{array}$ & $\begin{array}{c}-0.028 \ddagger \\
-0.003\end{array}$ & $\begin{array}{c}-0.107 \$ \\
0.005\end{array}$ & $\begin{array}{c}-0.019 \dagger \\
0.013\end{array}$ & $\begin{array}{l}0.012 \\
0.003\end{array}$ \\
\hline $\begin{array}{l}\text { Divs-to- } \\
\text { Equity }\end{array}$ & 0.019 & 0.018 & -0.005 & 0.013 & 0.002 & 0.013 & 0.004 & 0.013 \\
\hline $\begin{array}{l}\text { Tang-to- } \\
\text { Assets }\end{array}$ & $-0.105 \ddagger$ & $-0.068 \ddagger$ & $-0.071+$ & $-0.078+$ & -0.015 & -0.011 & -0.002 & $-0.022 \dagger$ \\
\hline $\begin{array}{l}\text { Stock } \\
\text { Price }\end{array}$ & $0.099 \$$ & $0.102+$ & $0.086 \ddagger$ & $0.029 \ddagger$ & $0.026+$ & $0.098 \ddagger$ & 0.012 & $0.105 \neq$ \\
\hline $\begin{array}{l}\text { Sales } \\
\text { Growth }\end{array}$ & 0.001 & 0.000 & -0.008 & 0.001 & 0.001 & $-0.019^{*}$ & 0.017 & -0.005 \\
\hline $\begin{array}{l}\text { Book-to- } \\
\text { Mkt }\end{array}$ & $-0.070 \ddagger$ & $-0.094 \ddagger$ & 0.003 & $-0.038+$ & -0.008 & $-0.045 \ddagger$ & $-0.021^{*}$ & $-0.020^{*}$ \\
\hline S\&P 500 & $0.071+$ & 0.254 屯 & $0.131 \ddagger$ & -0.067末 & 0.006 & $0.216 \ddagger$ & 0.000 & -0.045 \\
\hline
\end{tabular}


No. 1:1]

CORRELATION MATRIX ${ }^{307}$

\begin{tabular}{|c|c|c|c|c|c|c|c|c|}
\hline $\begin{array}{l}\text { Index } \\
\text { CGQ }\end{array}$ & $\begin{array}{c}\text { Industry } \\
\text { CGQ }\end{array}$ & $\begin{array}{c}\text { ISS } \\
\text { Internal }\end{array}$ & E-Index & G-Index & $\begin{array}{l}\text { ISS } \\
\text { Ext. }\end{array}$ & $\begin{array}{l}\text { Annual } \\
\text { Director } \\
\text { Election }\end{array}$ & $\begin{array}{c}\text { Del. } \\
\text { Incorp. }\end{array}$ & $\begin{array}{l}\text { Irreg, } \\
\text { Restmt }\end{array}$ \\
\hline
\end{tabular}

\begin{tabular}{|c|c|c|c|c|c|c|c|c|}
\hline $0.745 \ddagger$ & 1.000 & & & & & & & \\
\hline $0.272 \dagger$ & $0.385 \neq$ & 1.000 & & & & & & \\
\hline$-0.072 \$$ & $-0.037 \neq$ & -0.040 本 & 1.000 & & & & & \\
\hline $\begin{array}{l}-0.006 \\
0.123 \ddagger\end{array}$ & $\begin{array}{l}0.061 末 \\
0.098 *\end{array}$ & $\begin{array}{l}0.130 \% \\
0.410 \%\end{array}$ & $\begin{array}{c}0.668 \ddagger \\
-0.513 \ddagger\end{array}$ & $\begin{array}{c}1.000 \\
-0.654+\end{array}$ & 1.000 & & & \\
\hline $0.183 \ddagger$ & $0.165+$ & -0.010 & $-0.554 \ddagger$ & $-0.483 \ddagger$ & $0.459 \neq$ & 1.000 & & \\
\hline$-0.028 \$$ & $0.058 \neq$ & $-0.032+$ & $-0.076 \neq$ & -0.155 & $0.209 \ddagger$ & $-0.022 \dagger$ & 1.000 & \\
\hline-0.012 & 0.002 & 0.015 & $-0.020^{*}$ & $-0.030 \dagger$ & $0.026 \neq$ & 0.005 & 0.013 & 1.000 \\
\hline 0.012 & $0.159 \ddagger$ & $0.119 \neq$ & $-0.184 \ddagger$ & $-0.087+$ & $0.087 \neq$ & $0.125 \ddagger$ & 0.004 & $0.020 \dagger$ \\
\hline $0.021 \dagger$ & $0.117 \ddagger$ & $0.022 \dagger$ & $-0.076 \ddagger$ & $-0.052+$ & $0.033 \neq$ & $0.094 \ddagger$ & $0.042 \ddagger$ & 0.010 \\
\hline$-0.070 \$$ & $0.246 \neq$ & $0.142 \ddagger$ & $-0.086 \ddagger$ & 0.014 & $0.048 \ddagger$ & $0.053 \ddagger$ & $0.144 \ddagger$ & 0.003 \\
\hline$-0.077 \$$ & $0.237 \ddagger$ & $0.089 \ddagger$ & $-0.049 \ddagger$ & -0.003 & $0.027 \neq$ & $0.066+$ & $0.166+$ & -0.014 \\
\hline $0.027 \ddagger$ & $0.065 \$$ & $0.047 \ddagger$ & $0.0340 \ddagger$ & $0.159 \ddagger$ & $-0.069 \ddagger$ & -0.009 & $-0.074 \ddagger$ & 0.001 \\
\hline-0.009 & $0.114 \neq$ & $0.081 \neq$ & $-0.123 \ddagger$ & $-0.069+$ & $0.071+$ & $0.099 \ddagger$ & $0.055 \ddagger$ & $0.032+$ \\
\hline $0.100 \ddagger$ & $0.203 \ddagger$ & $0.140 \ddagger$ & 0.009 & $0.247 \ddagger$ & $-0.094 \ddagger$ & $0.060 \ddagger$ & $-0.203 \ddagger$ & -0.003 \\
\hline $\begin{array}{l}-0.001 \\
0.002\end{array}$ & $\begin{array}{c}-0.072 \$ \\
0.022 \dagger\end{array}$ & $\begin{array}{c}-0.263 \$ \\
-0.008\end{array}$ & $\begin{array}{l}0.015 \\
0.011\end{array}$ & $\begin{array}{l}-0.081+ \\
-0.017\end{array}$ & $\begin{array}{c}-0.080 \ddagger \\
-0.007\end{array}$ & $\begin{array}{c}0.052 \ddagger \\
-0.010\end{array}$ & $\begin{array}{c}0.085 \ddagger \\
0.016\end{array}$ & $\begin{array}{l}0.018^{*} \\
0.020^{*}\end{array}$ \\
\hline-0.013 & 0.010 & 0.019 & 0.012 & -0.004 & 0.006 & -0.000 & 0.013 & -0.005 \\
\hline 0.004 & $-0.117 \ddagger$ & $-0.028 \dagger$ & $0.037 \ddagger$ & 0.033 & $-0.055 \ddagger$ & $-0.033 \ddagger$ & $-0.072 \ddagger$ & -0.029 \\
\hline$-0.033 \$$ & $0.080 \neq$ & $0.149 \ddagger$ & $-0.041 \ddagger$ & 0.003 & $0.047 \neq$ & -0.001 & $0.021^{*}$ & $-0.032+$ \\
\hline $0.019^{*}$ & 0.007 & $-0.025 \dagger$ & $0.026 \dagger$ & $-0.041+$ & -0.012 & 0.008 & $0.039 \ddagger$ & -0.003 \\
\hline $0.049 \ddagger$ & -0.009 & $-0.106+$ & $0.040 \ddagger$ & -0.011 & $-0.048 \ddagger$ & $0.034 \ddagger$ & $-0.050 \ddagger$ & 0.007 \\
\hline$-0.066 \$$ & $0.280 \neq$ & $0.139 \ddagger$ & $-0.039 \ddagger$ & $0.123 \ddagger$ & $-0.024 \dagger$ & $0.080 \ddagger$ & 0.001 & 0.010 \\
\hline
\end{tabular}


TABLE 2:

\begin{tabular}{|c|c|c|c|c|c|c|c|}
\hline & $\begin{array}{l}\text { Market } \\
\text { Cap }\end{array}$ & $\begin{array}{l}\text { Trading } \\
\text { Volume }\end{array}$ & $\begin{array}{l}\text { Research } \\
\text { Coverage }\end{array}$ & $\begin{array}{l}\text { Research } \\
\text { Activity }\end{array}$ & $\begin{array}{l}\text { Industry } \\
\text { Diversity }\end{array}$ & $\begin{array}{l}\text { News } \\
\text { Story } \\
\text { Mentions }\end{array}$ & Age \\
\hline $\begin{array}{l}\text { Market } \\
\text { Cap }\end{array}$ & 1.000 & & & & & & \\
\hline $\begin{array}{l}\text { Trading } \\
\text { Volume }\end{array}$ & $0.339+$ & 1.000 & & & & & \\
\hline $\begin{array}{l}\text { Research } \\
\text { Coverage }\end{array}$ & $0.389 \ddagger$ & 0.245 & 1.000 & & & & \\
\hline $\begin{array}{l}\text { Research } \\
\text { Activity }\end{array}$ & $0.338 \neq$ & $0.284 \neq$ & $0.851 \ddagger$ & 1.000 & & & \\
\hline $\begin{array}{l}\text { Industry } \\
\text { Diversity }\end{array}$ & 0.118 & 0.048 & $0.046+$ & 0.009 & 1.000 & & \\
\hline $\begin{array}{l}\text { News } \\
\text { Stories }\end{array}$ & 0.515 & $0.310+$ & $0.305 \ddagger$ & $0.259 \ddagger$ & 0.105 & 1.000 & \\
\hline Age & 0.266 & 0.115 & $0.175 \ddagger$ & $0.134 \ddagger$ & $0.301 \ddagger$ & $0.173 \ddagger$ & 1.000 \\
\hline $\begin{array}{l}\text { Volatility } \\
\text { Return-on- }\end{array}$ & $-0.143 \$$ & $0.102+$ & $-0.137 \ddagger$ & 0.000 & $-0.075 \ddagger$ & -0.058 & $-0.117 \ddagger$ \\
\hline $\begin{array}{l}\text { Return-on- } \\
\text { Equity }\end{array}$ & 0.007 & 0.002 & 0.017 & 0.012 & -0.004 & 0.005 & 0.013 \\
\hline $\begin{array}{l}\text { Dividends- } \\
\text { to-Equity }\end{array}$ & 0.008 & 0.003 & 0.004 & 0.011 & 0.005 & 0.004 & 0.016 \\
\hline $\begin{array}{l}\text { Tang-to- } \\
\text { Total }\end{array}$ & -0.020 & $-0.019^{*}$ & $0.062+$ & 0.138 & -0.007 & -0.016 & $0.079 \$$ \\
\hline $\begin{array}{l}\text { Stock } \\
\text { Price }\end{array}$ & $0.172 \$$ & $-0.022 \dagger$ & $0.185 \ddagger$ & $0.144 \ddagger$ & $0.065 \ddagger$ & $0.104 \ddagger$ & $0.089 \ddagger$ \\
\hline $\begin{array}{l}\text { Sales } \\
\text { Growth }\end{array}$ & 0.000 & 0.001 & -0.001 & -0.002 & $-0.027 \dagger$ & -0.003 & $-0.030+$ \\
\hline $\begin{array}{l}\text { Book-to- } \\
\text { Market }\end{array}$ & $-0.049+$ & 0.063 & $-0.062+$ & -0.013 & -0.017 & $-0.028 \dagger$ & -0.017 \\
\hline $\begin{array}{l}\text { S\&P 500 } \\
\text { Member }\end{array}$ & 0.370 & 0.225 & 0.568 & $0.474 \ddagger$ & $0.176 \dagger$ & $0.287 \ddagger$ & $0.376 \ddagger$ \\
\hline
\end{tabular}


CORRELATION MATRIX (CONT.)

\begin{tabular}{|c|c|c|c|c|c|c|c|}
\hline $\begin{array}{l}\text { Vol- } \\
\text { atility }\end{array}$ & $\begin{array}{l}\text { Return- } \\
\text { on- } \\
\text { Equity }\end{array}$ & $\begin{array}{l}\text { Dividends } \\
\text {-to-Equity }\end{array}$ & $\begin{array}{l}\text { Tangible } \\
\text {-to-Total } \\
\text { Assets }\end{array}$ & $\begin{array}{l}\text { Stock } \\
\text { Price }\end{array}$ & $\begin{array}{l}\text { Sales } \\
\text { Growth }\end{array}$ & $\begin{array}{l}\text { Book-to- } \\
\text { Market } \\
\text { Equity }\end{array}$ & $\begin{array}{l}\text { S\&P } 500 \\
\text { Member }\end{array}$ \\
\hline
\end{tabular}

\begin{tabular}{|c|c|c|c|c|c|c|c|}
\hline $\begin{array}{l}1.000 \\
-0.020^{*}\end{array}$ & 1.000 & & & & & & \\
\hline-0.016 & $0.023 \dagger$ & 1.000 & & & & & \\
\hline$-0.023 \dagger$ & 0.004 & 0.005 & 1.000 & & & & \\
\hline$-0.261+$ & 0.009 & -0.005 & $-0.050+$ & 1.000 & & & \\
\hline $0.030+$ & -0.000 & -0.003 & -0.002 & $0.024 \dagger$ & 1.000 & & \\
\hline 0.175 & $-0.038+$ & -0.013 & $0.045 \ddagger$ & $-0.097+$ & $0.061 \ddagger$ & 1.000 & \\
\hline$-0.144+$ & $0.032 \ddagger$ & 0.027 & $-0.025 \dagger$ & $0.167 \ddagger$ & $-0.018^{*}$ & $-0.037 \ddagger$ & 1.000 \\
\hline
\end{tabular}

307 Table 2 reports pairwise correlation coefficients for the variables used in the analysis of the relationship between institutional ownership and corporate governance. $*$, $\dagger$, and $\ddagger$ indicate significance at the $10 \%, 5 \%$ and 1\% levels, respectively. Higher values of "ISS Index CGQ," "ISS Industry CGQ," and "ISS Internal Governance Score" reflect higher quality (primarily or exclusively internal governance (e.g., board independence). Higher values of "E-Index" and "G-Index" reflect lower quality external governance (i.e., less exposure to the market for corporate control). Lower values of "ISS External Governance Score" represent lower quality external governance. "Annual director elections (i.e., no staggered board)" is a measure of high-quality external governance. 


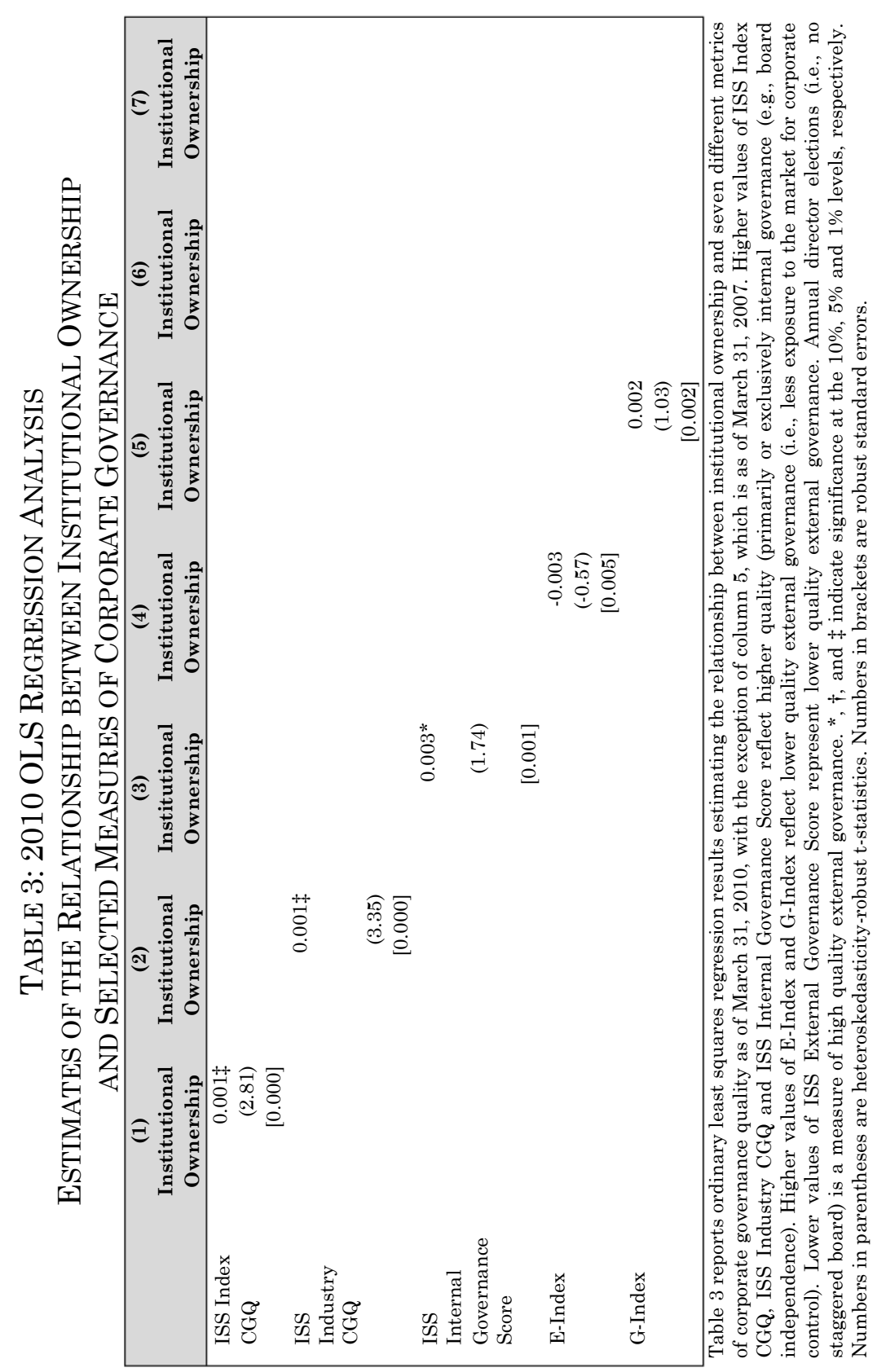




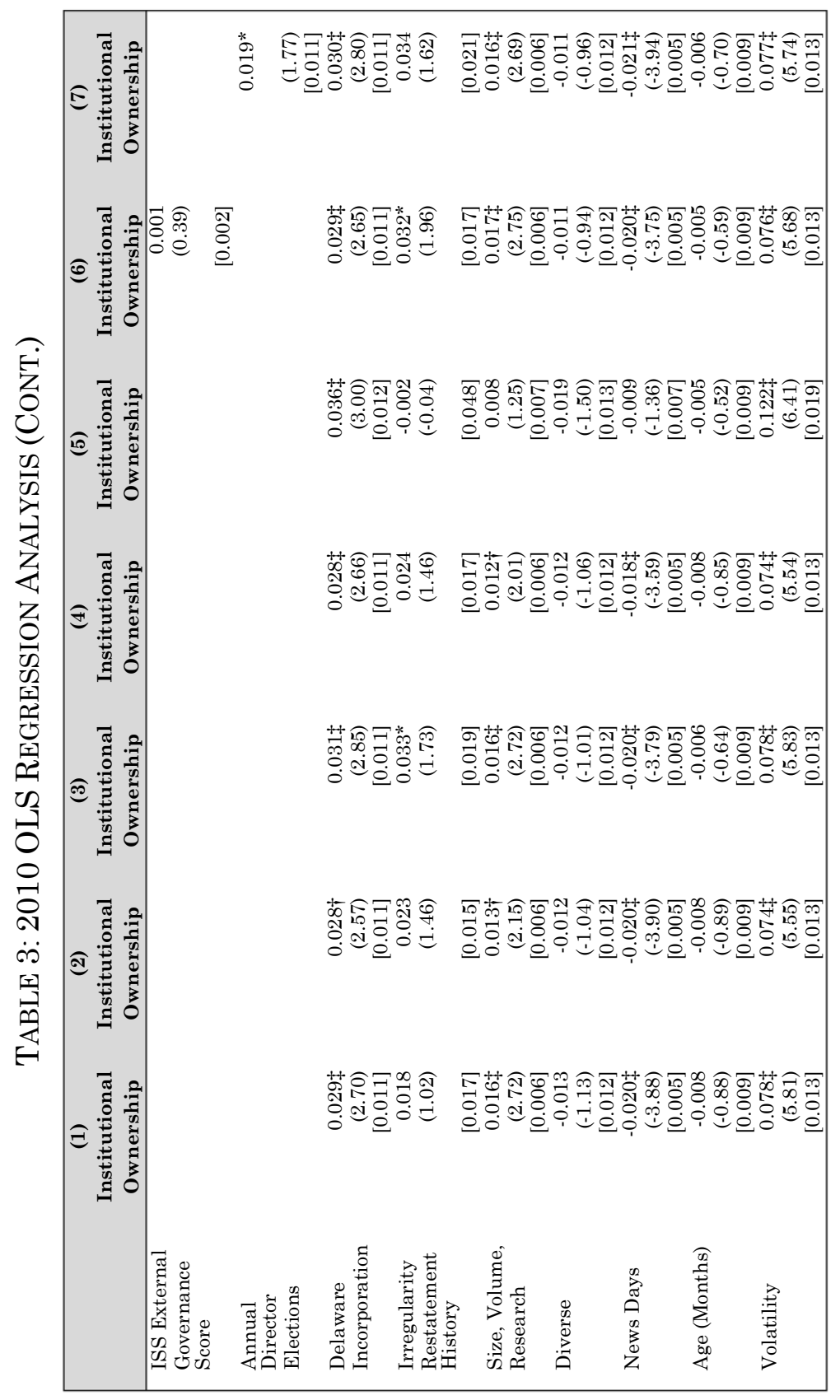




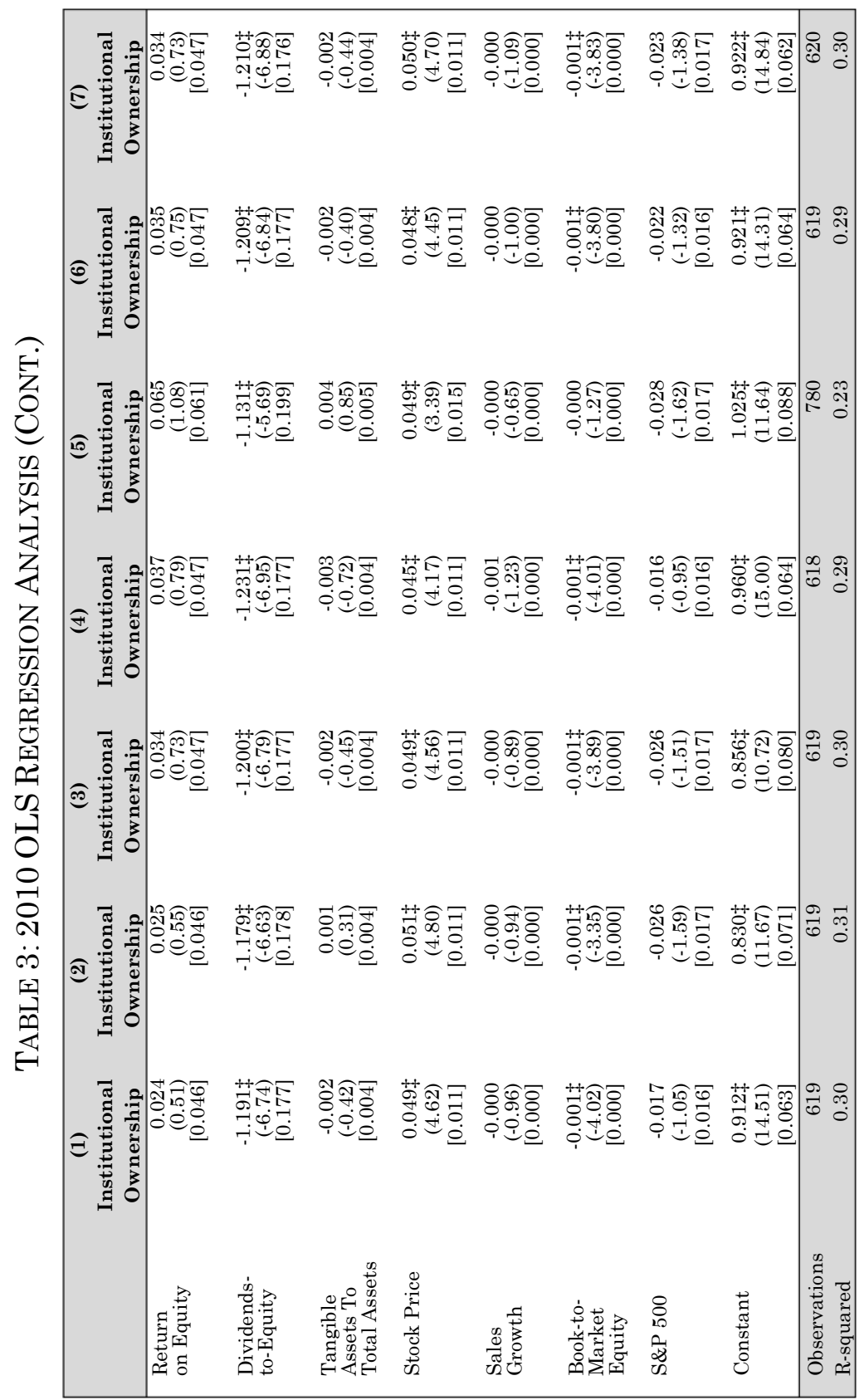


No. 1:1]

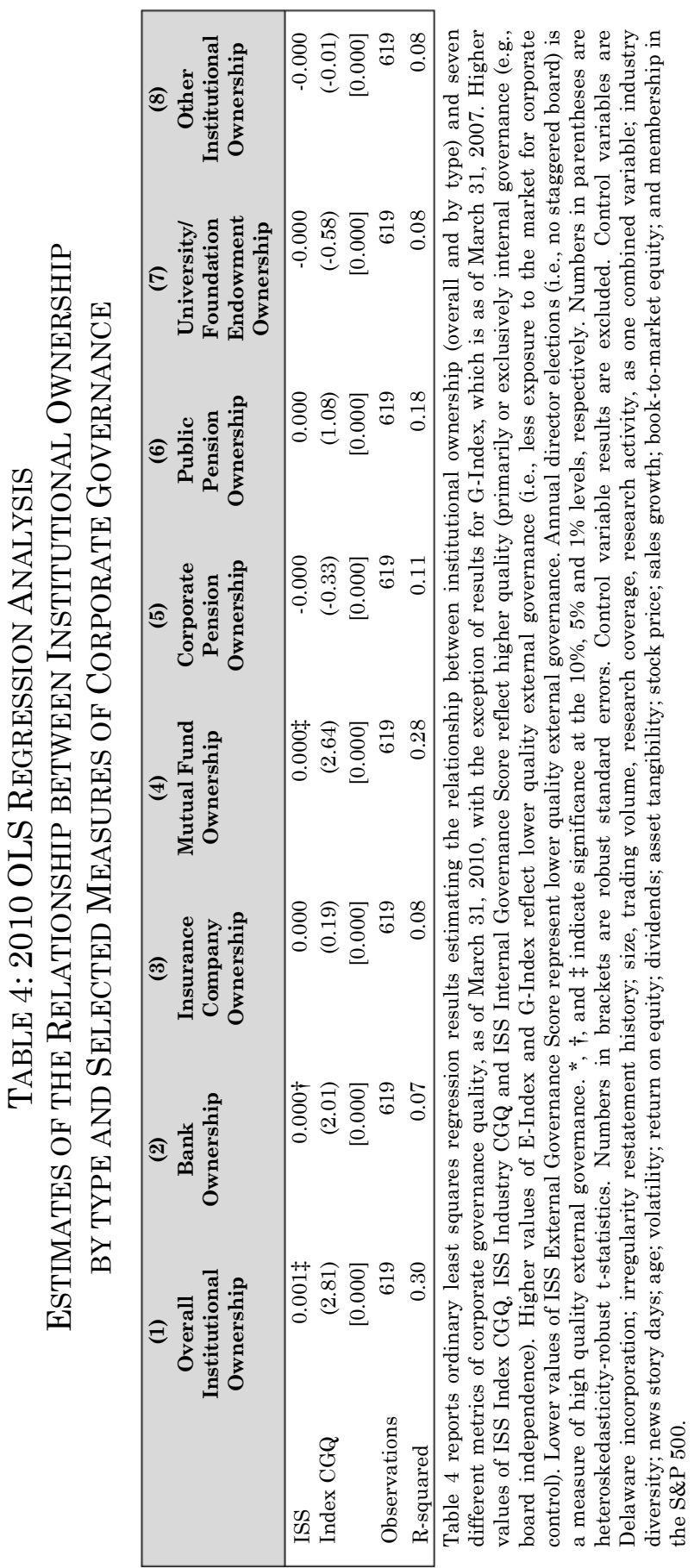




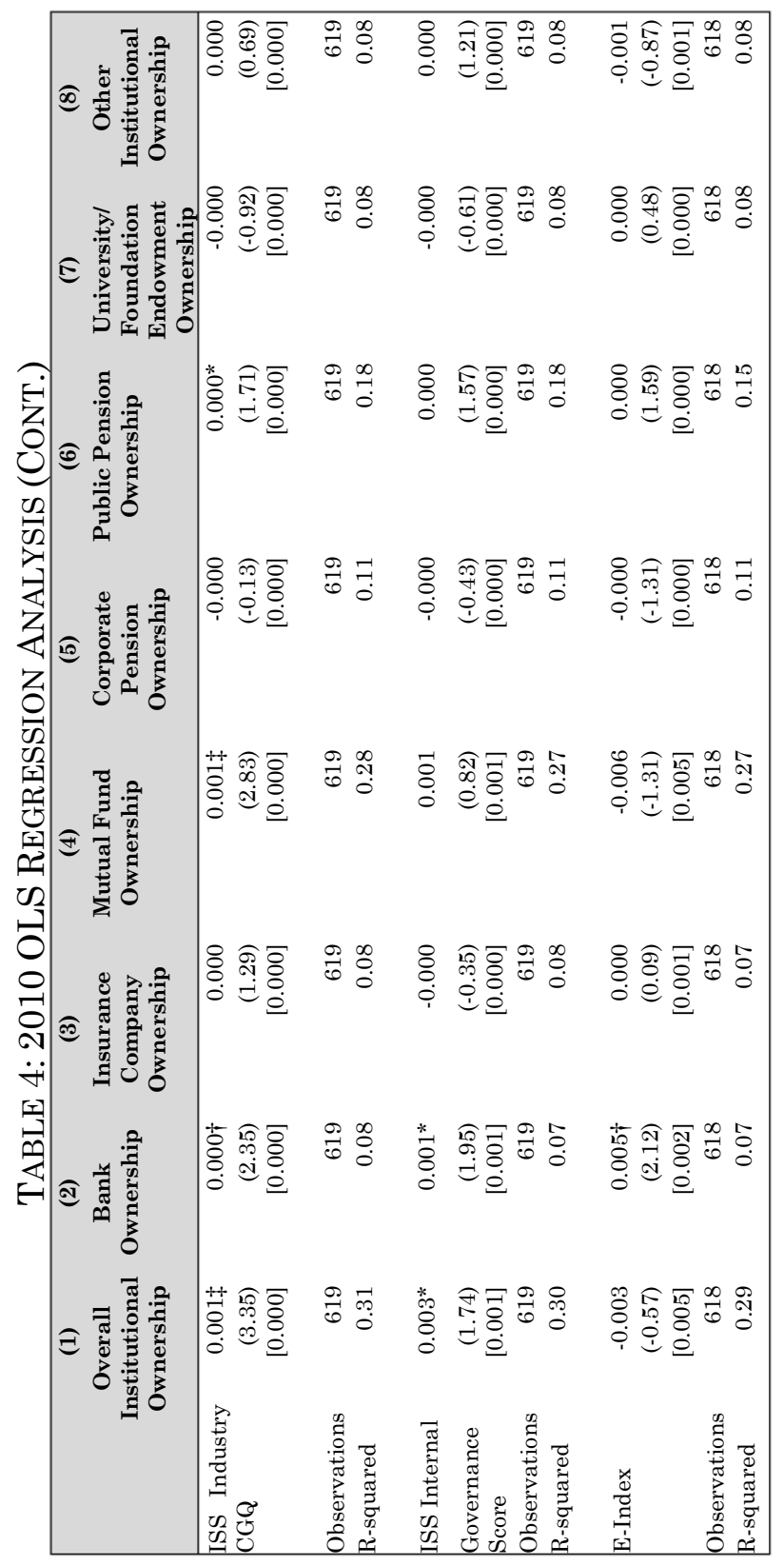




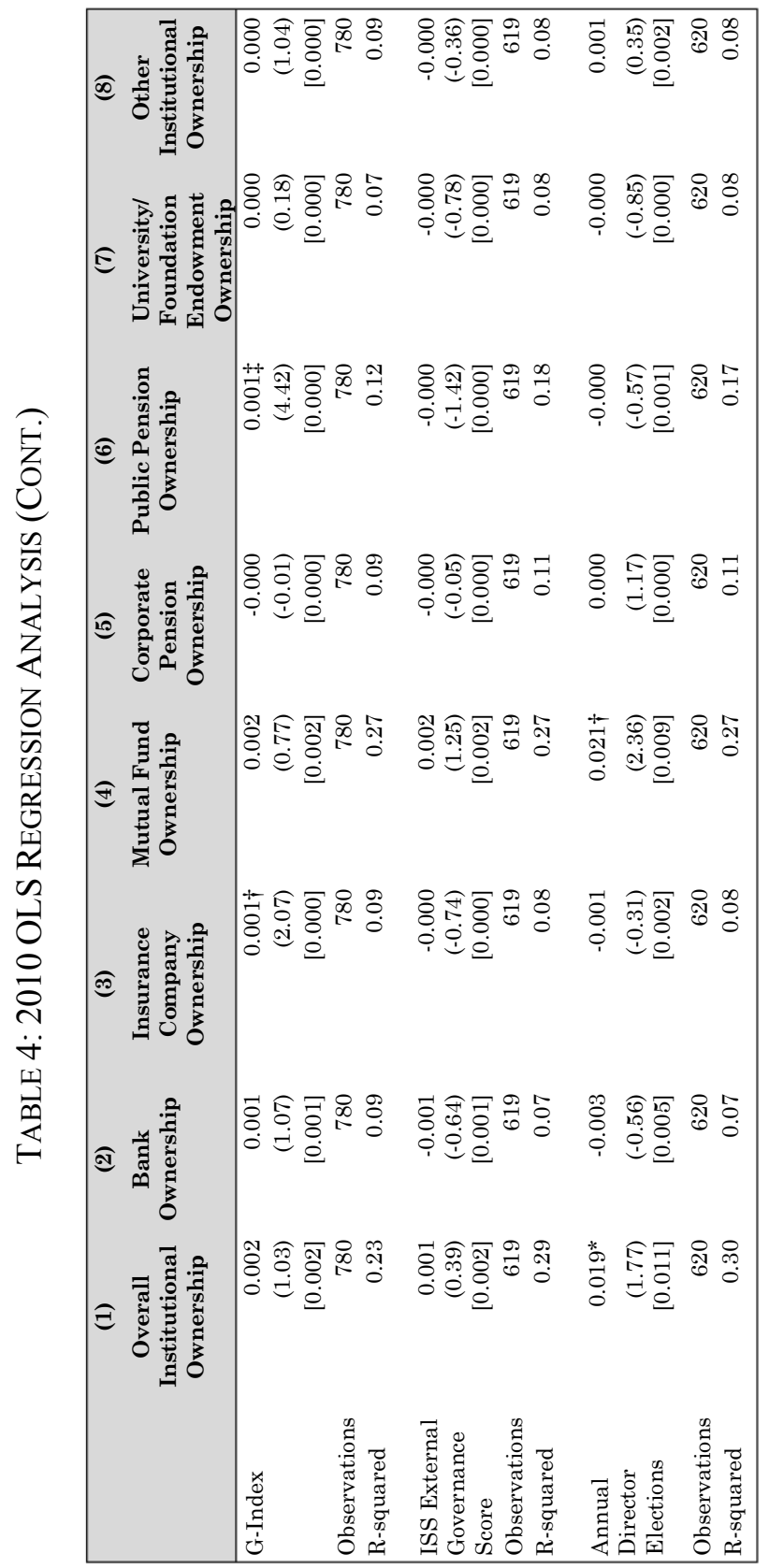




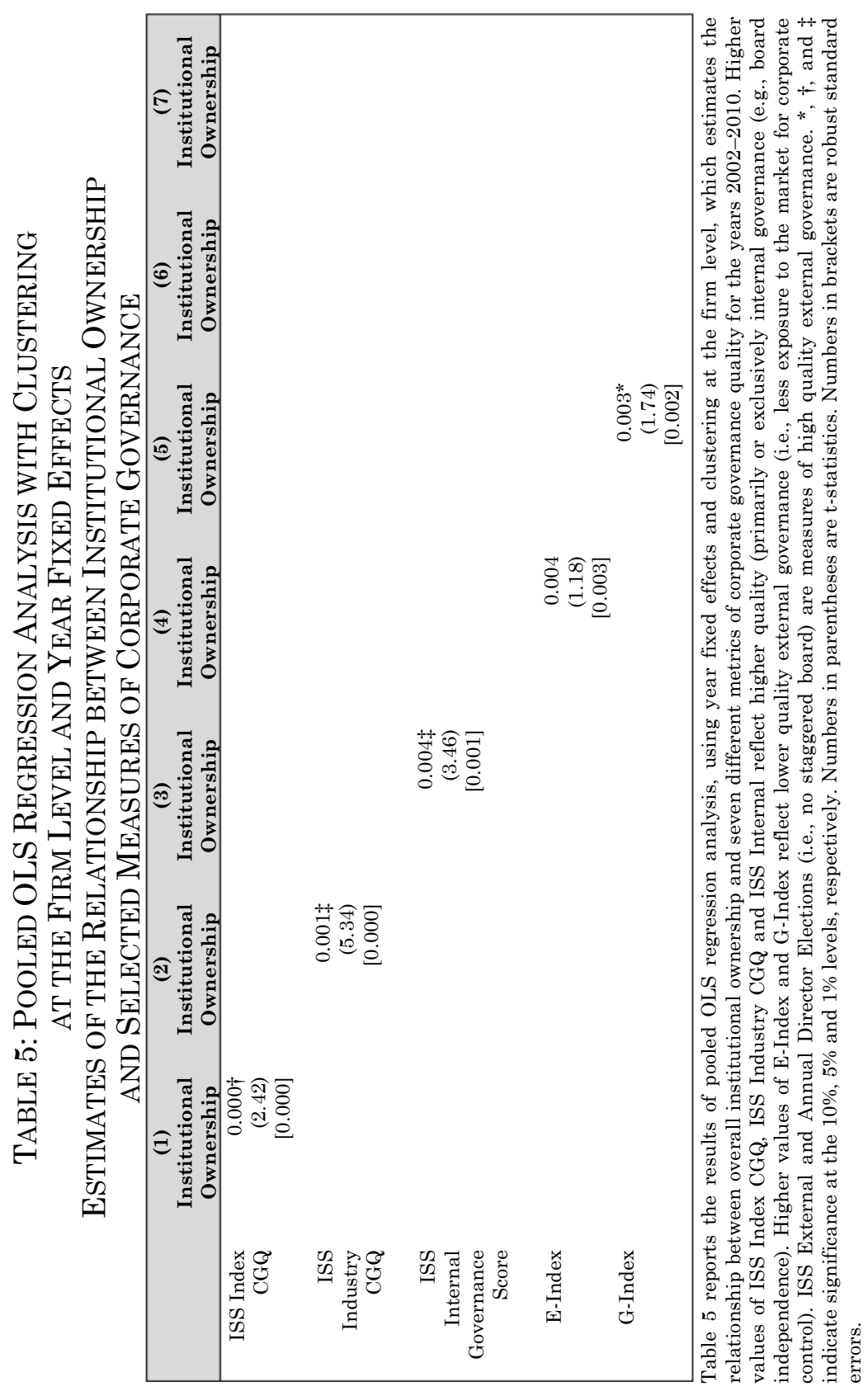




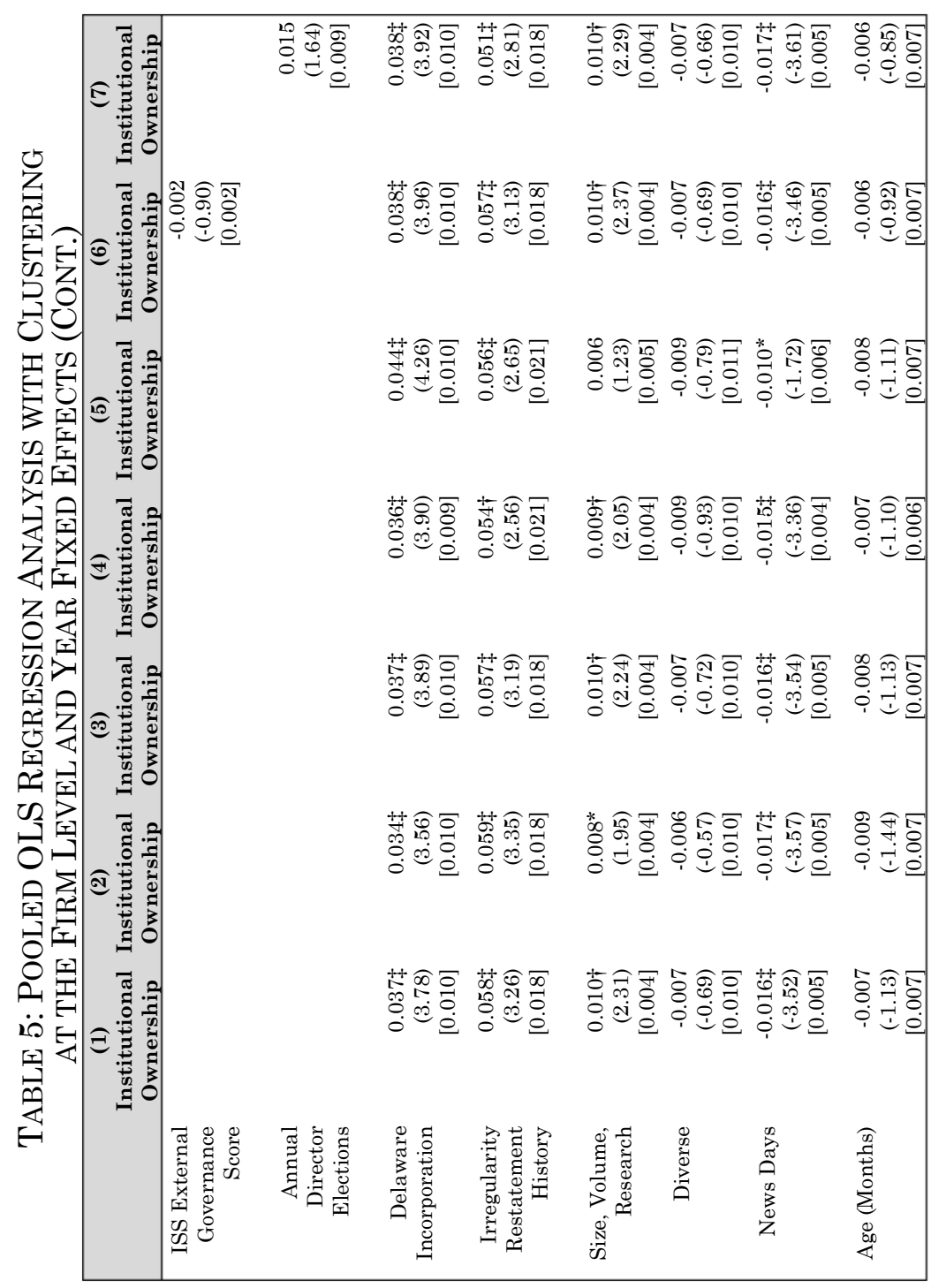


[Vol. 2015

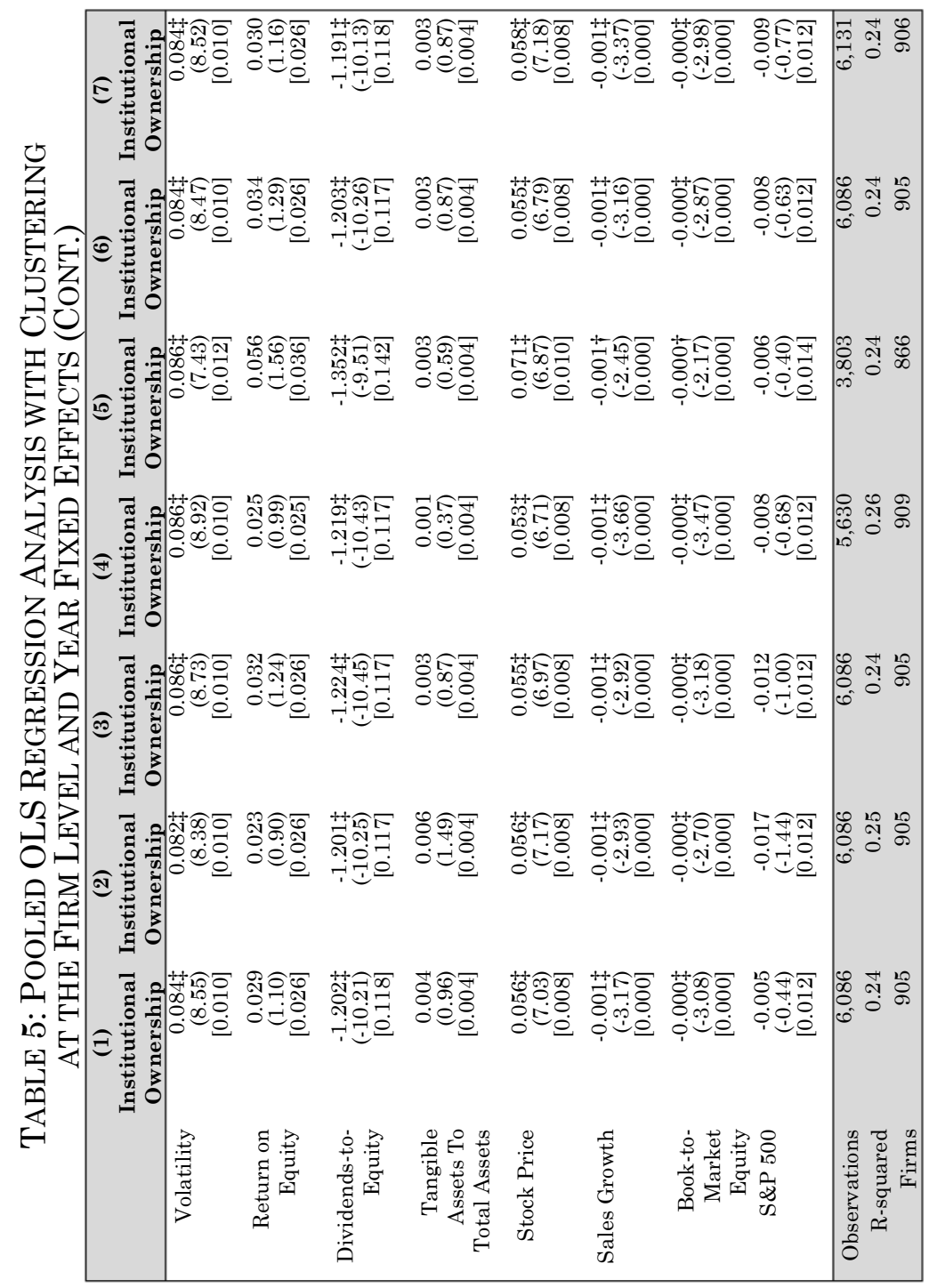


No. 1:1]

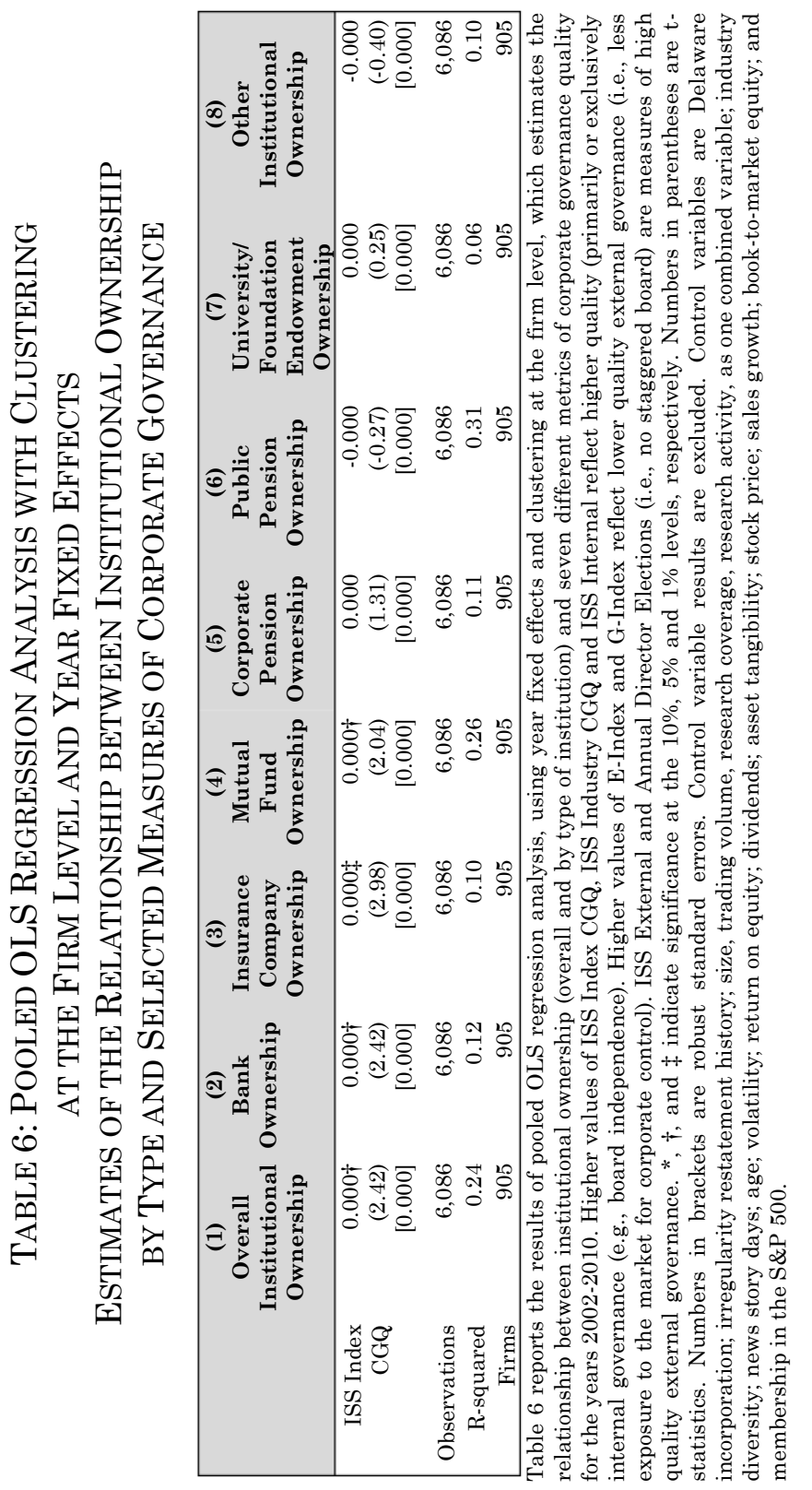




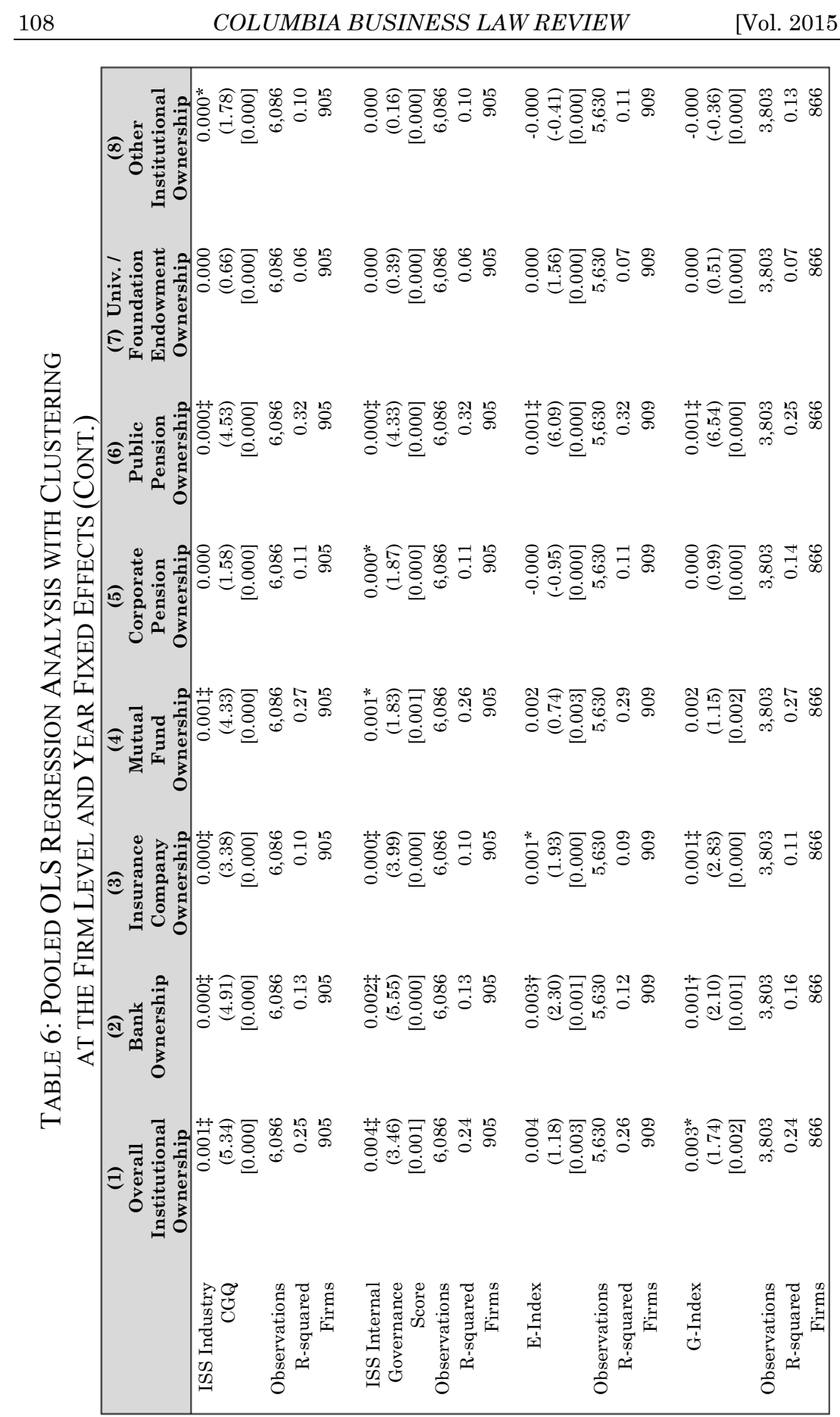


No. 1:1]

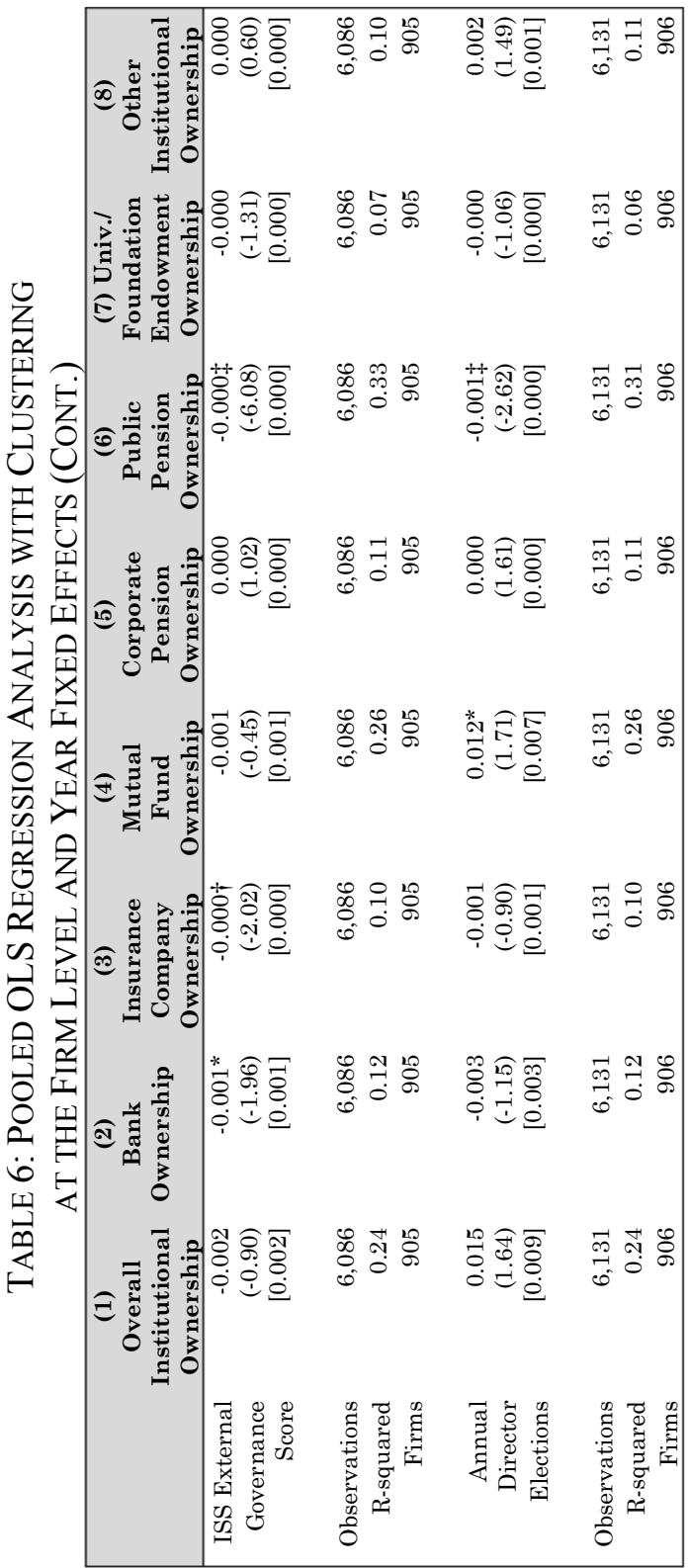




\section{APPENDIX A: INSTITUTIONAL SHAREHOLDER SERVICES CORPORATE GOVERNANCE QUOTIENT FACTORS ${ }^{308}$}

A. Board Issues

1. At least two-thirds of the directors on the board should be independent.

2. The nominating committee of the board should be composed solely of independent directors.

3. The compensation committee of the board should be composed solely of independent directors.

4. The functions of a governance committee should be handled by a committee of the board, typically the nominating committee or the governance committee.

5. Directors should be accountable to shareholders on an annual basis. [No staggered board.]

6. Boards should not have fewer than 6 members or more than 15 members.

7. Shareholders should have the right to vote on changes to expand or contract the size of the board.

8. Shareholders should have the right to cumulate their votes for directors.

9. In addition to serving on his own company's board, the CEO should not serve on more than two other boards of public companies.

10. Outside directorships should be limited to service on the boards of five or fewer public companies. (Note: Raw data indicates number is four boards, not five.)

11. Former CEOs should not serve on the board of directors.

12. The positions of chairman and CEO should be separated or a lead director should be specified.

13. Board guidelines should be published in the proxy on an annual basis.

308 ISS Best Practices User Guide \& Glossary (2003). This list ignores combination factors. CGQ factors differ slightly in the years 2006 2010. Items in bold (Nos. 23-27, 33-34,60) are omitted from the analysis of individual governance factors for the reasons described above. 
14. Management should take action on all shareholder proposals supported by a majority vote within 12 months of the shareholders' meeting.

15. Directors should attend at least $75 \%$ of board meetings.

16. Shareholders should be given an opportunity to vote on all directors selected to fill vacancies.

17. CEOs should not be the subject of transactions that create conflicts of interest as disclosed in the proxy statement.

B. Audit

18. The audit committee of the board should be composed solely of independent directors.

19. The company should disclose its policy with respect to the rotation of auditors.

20. Consulting fees (audit-related and other) should be less than audit fees.

21. Shareholders should be permitted to ratify management's selection of auditors each year.

C. Charter/Bylaws

22. No poison pill or shareholder approved poison pill.

23. [Omit because combined no poison pill with shareholder approved poison pill because it is not possible to get points in both categories.]

24. If there is a poison pill, it should have a threeyear independent director evaluation. [Omit because only applies to subset of companies with poison pills]

25. If there is a poison pill, it should have a sunset provision. [Omit because only applies to subset of companies with poison pills]

26. If there is a poison pill, it should have a qualified offer clause. [Omit because only applies to subset of companies with poison pills] 
27. If there is a poison pill, it should have a trigger threshold of 20 percent or more. [Omit because only applies to subset of companies with poison pills]

28. A simple majority vote should be required to amend the charter/bylaws.

29. A simple majority vote should be required to approve mergers or business combinations

30. Shareholders should be permitted to act by written consent.

31. Shareholders should be permitted to call special meetings.

32. Management should not be permitted to amend the bylaws without shareholder approval.

33. [Omit because discrepancy between raw data ("Single class of stock, with or without blank check preferred") and ISS standard which states: Common stock entitled to one vote per share and declawed preferred stock are viewed favorably.]

\section{Antitakeover Provisions}

33. The company is incorporated in a state with no antitakeover statutes. [Omit because of potential for overlap with $35-40]$

34. The company is incorporated in a state without a control share acquisition statute or has opted out.

35. The company is incorporated in a state without a control share cash out statute or has opted out.

36. The company is incorporated in a state without a freezeout statute or has opted out.

37. The company is incorporated in a state without a fair price provision statute or has opted out.

38. The company is not incorporated in a state with a stakeholder constituency statute or has opted out.

39. The company is not incorporated in a state with a poison pill endorsement statute. 
E. Executive and Director Compensation

40. The cost of the company's stock-based incentive plans is not more than ISS' cap.

41. Options have not been repriced in the past [three years] without prior shareholder approval.

42. Company policy prohibits option repricing without prior shareholder approval.

43. All stock-based incentive plans should be submitted to shareholders for approval.

44. No interlocking directors should serve on the Compensation Committee.

45. Directors should receive a portion of their compensation in the form of stock.

46. Non-Employee directors should not participate in pension plans.

47. The company has adopted FAS 123 and expenses options.

48. The company's burn rate is excessive where average annual option grants exceed three percent of outstanding shares over the past three years.

49. New loan programs under stock option plans are prohibited.

\section{F. Progressive Practices}

50. Directors are subject to mandatory retirement age or term limits

51. A policy of conducting regular board performance reviews should be disclosed.

52. A policy specifying that directors should meet without the CEO should be disclosed.

53. A board-approved CEO succession plan should be in place.

54. A policy authorizing the board to hire its own advisors should be disclosed.

55. A policy requiring directors to resign upon a change in job status should be disclosed. 
G. Ownership

56. Each director [with more than one year of service] owns stock in the company.

57. Executives should be subject to stock ownership guidelines.

58. Directors should be subject to stock ownership guidelines.

59. Officers and directors should have a significant ownership position in their company's stock. [Omit because no percentage specified by ISS]

H. Director Education

60. All board members should participate in "ISS accredited" director education programs.

APPENDIX B: ISS INTERNAL FACTORS ${ }^{309}$

A. Board Issues

1. At least two-thirds of the directors on the board should be independent.

2. The nominating committee of the board should be composed solely of independent directors.

3. The compensation committee of the board should be composed solely of independent directors.

4. The functions of a governance committee should be handled by a committee of the board, typically the nominating committee or the governance committee.

5. Boards should not have fewer than 6 members or more than 15 members.

6. Shareholders should have the right to cumulate their votes for directors.

309 If ISS data indicate company's disclosures do not provide the information, firm gets no points under my analysis. This is a rare occurrence. CGQ factors differ slightly in the years 2006-2010. Also, item in bold (No. 60) is omitted from the analysis of individual governance factors for the reason described above. 
8. In addition to serving on his own company's board, the CEO should not serve on more than two other boards of public companies.

9. Outside directorships should be limited to service on the boards of five or fewer public companies. (Note: Raw data indicates number is four boards, not five.)

10. Former CEOs should not serve on the board of directors.

11. The positions of chairman and CEO should be separated or a lead director should be specified.

12. Board guidelines should be published in the proxy on an annual basis.

13. Management should take action on all shareholder proposals supported by a majority vote within 12 months of the shareholders' meeting.

14. Directors should attend at least $75 \%$ of board meetings.

15. CEOs should not be the subject of transactions that create conflicts of interest as disclosed in the proxy statement.

B. Audit

18. The audit committee of the board should be composed solely of independent directors.

19. The company should disclose its policy with respect to the rotation of auditors.

20. Consulting fees (audit-related and other) should be less than audit fees.

21. Shareholders should be permitted to ratify management's selection of auditors each year.

\section{Executive and Director Compensation}

41. The cost of the company's stock-based incentive plans is not more than ISS' cap.

42. Options have not been repriced in the past [three years] without prior shareholder approval. 
43. Company policy prohibits option repricing without prior shareholder approval.

44. All stock-based incentive plans should be submitted to shareholders for approval.

45. No interlocking directors should serve on the Compensation Committee.

46. Directors should receive a portion of their compensation in the form of stock.

47. Non-employee directors should not participate in pension plans.

48. The company has adopted FAS 123 and expenses options.

49. The company's burn rate is excessive where average annual option grants exceed three percent of outstanding shares over the past three years.

50. New loan programs under stock option plans are prohibited.

\section{Progressive Practices}

51. Directors are subject to mandatory retirement age or term limits

52. A policy of conducting regular board performance reviews should be disclosed.

53. A policy specifying that directors should meet without the CEO should be disclosed.

54. A board-approved CEO succession plan should be in place.

55. A policy authorizing the board to hire its own advisors should be disclosed.

56. A policy requiring directors to resign upon a change in job status should be disclosed.

\section{E. Ownership}

57. Each director [with more than one year of service] owns stock in the company.

58. Executives should be subject to stock ownership guidelines. 
59. Directors should be subject to stock ownership guidelines.

60. Officers and directors should have a significant ownership position in their company's stock. [Omit because no percentage specified by ISS]

F. Director Education

61. All board members should participate in "ISS accredited" director education programs.

APPENDIX C: ENTRENCHMENT INDEX

The Entrenchment Index is based on the following six provisions:

1. Staggered (classified) boards

2. Limits on shareholder bylaw amendments

3. Supermajority voting requirements for mergers

4. Supermajority voting requirements for charter amendments

5. Poison pills

6. Golden parachutes

APPENDIX D: G-INDEX ${ }^{310}$

A. Delay

1. Blank Check

2. Classified Board

3. Special Meeting

4. Written Consent

310 The G-Index is based on 28 provisions-22 firm-level characteristics and 6 state laws, 4 of which are analogous to 4 of the firmlevel characteristics, for a net 24 provisions. Paul Gompers, Joy Ishii \& Andrew Metrick, Corporate Governance and Equity Prices, 118 Q. J. Econ. 107 (2003). 
B. Protection

1. Compensation Plans

2. Contracts

3. Golden Parachutes

4. Indemnification

5. Liability

6. Severance

C. Voting

1. Bylaws

2. Charter

3. Cumulative Voting

4. Secret Ballot

5. Supermajority

6. Unequal Voting

D. Other

1. Antigreenmail

2. Directors' Duties

3. Fair Price

4. Pension Parachutes

5. Poison Pill

6. Silver Parachutes

E. State

1. Antigreenmail Law

2. Business Combination Law

3. Cash-out Law

4. Directors' Duties Law

5. Fair Price Law

6. Control Share Acquisition Law 


\section{APPENDIX E: ISS EXTERNAL FACTORS ${ }^{311}$}

A. Board Issues

5. Directors should be accountable to shareholders on an annual basis [No staggered board].

7. Shareholders should have the right to vote on changes to expand or contract the size of the board.

16. Shareholders should be given an opportunity to vote on all directors selected to fill vacancies.

B. Charter/Bylaws

22. No poison pill or shareholder approved poison pill

23. [Omit because combined no poison pill with shareholder approved poison pill because it is not possible to get points in both categories.]

24. If there is a poison pill, it should have a threeyear independent director evaluation. [Omit because only applies to subset of companies with poison pills]

25. If there is a poison pill, it should have a sunset provision. [Omit because only applies to subset of companies with poison pills]

26. If there is a poison pill, it should have a qualified offer clause. [Omit because only applies to subset of companies with poison pills]

27. If there is a poison pill, it should have a trigger threshold of 20 percent or more. [Omit because only applies to subset of companies with poison pills]

28. A simple majority vote should be required to amend the charter/bylaws.

311 If ISS data indicate company's disclosures do not provide the information, firm gets no points under my analysis. This is a rare occurrence. CGQ factors differ slightly in the years 2006-2010. Also, items in bold (Nos. 23-27, 33-34) are omitted from the analysis of individual governance factors for the reason described above. 
29. A simple majority vote should be required to approve mergers or business combinations

30. Shareholders should be permitted to act by written consent.

31. Shareholders should be permitted to call special meetings.

32. Management should not be permitted to amend the bylaws without shareholder approval.

33. [Omit because discrepancy between raw data ("Single class of stock, with or without blank check preferred") and ISS standard which states: Common stock entitled to one vote per share and declawed preferred stock are viewed favorably.]

C. Antitakeover Provisions

34. The company is incorporated in a state with no antitakeover statutes. [Omit because of potential for overlap with $35-40]$

35. The company is incorporated in a state without a control share acquisition statute or has opted out.

36. The company is incorporated in a state without a control share cash out statute or has opted out.

37. The company is incorporated in a state without a freezeout statute or has opted out.

38. The company is incorporated in a state without a fair price provision statute or has opted out.

39. The company is not incorporated in a state with a stakeholder constituency statute or has opted out.

40. The company is not incorporated in a state with a poison pill endorsement statute. 